$10-2005$

Using Suppression Hearing Testimony to Prove Good Faith under

United States v. Leon

John E. Taylor

Follow this and additional works at: https://researchrepository.wvu.edu/law_faculty

Part of the Constitutional Law Commons, Evidence Commons, and the Fourth Amendment Commons 


\title{
Using Suppression Hearing Testimony to Prove Good Faith Under United States v. Leon
}

\author{
John E. Taylor
}

\section{INTRODUCTION}

Imagine a narcotics prosecution based largely on evidence obtained under the authority of a search warrant. At the suppression hearing, the defendant argues that the warrant is invalid under Illinois v. Gates ${ }^{1}$ because the affidavit supporting the warrant application failed to provide the magistrate with even a "substantial basis for concluding' that probable cause existed." 2 The defendant further argues that the fruits of the search must be suppressed despite the United States v. Leon ${ }^{3}$ good faith exception because the affidavit was "so lacking in indicia of probable cause as to render official belief in its existence entirely unreasonable." 4 When the trial court seems inclined to accept these arguments, the prosecution offers to introduce testimony from the affiant officer about information supporting probable cause that she knew at the time of the warrant application but neglected to present to the magistrate. It is clear that if this additional information had been included in the warrant application, the warrant would have been supported by probable cause. Does United States v. Leon allow the prosecution to use the affiant's suppression hearing testimony to cure the probable-cause deficiencies in the affidavit and establish the officer's good faith?

Most courts that have explicitly addressed this question have adopted bright-line rules, holding either that information known to the officer but not communicated to the magistrate can always be used to establish good

\footnotetext{
Associate Professor, West Virginia University College of Law. John.Taylor@mail.wvu.edu. I wish to thank Gerald Ashdown, Vivian Hamilton, and the audiences at a SEALS Young Scholars Workshop and a WVU College of Law faculty workshop for helpful comments. I also thank the Hodges Foundation for financial support of this project and Jeremy Jacobs and Kelly Kotur for providing able research assistance.

1. 462 U.S. 213 (1983).

2. Id. at 238-39 (quoting Jones v. United States, 362 U.S. 257, 271 (1960)).

3. 468 U.S. 897 (1984).

4. Id. at 923 (quoting Brown v. Illinois, 422 U.S. 590, 610-11 (1975) (Powell, J., concurring in part)).
} 
faith or that it never can. ${ }^{5}$ The intuitive force of both positions is easy to see. When an officer has submitted a deficient affidavit to the magistrate and then tries to cure its deficiencies with suppression hearing testimony, there seem to be two possibilities. Either the officer was carelessperhaps very careless - in her warrant application, or she did not yet know at the time of the warrant application the things she now claims she knew. Allowing suppression hearing testimony to cure the affidavit's deficiencies threatens (at best) to encourage sloppiness in the warrant application process and (at worst) to facilitate perjury. On the other hand, officers who plead that they "simply forgot" to include certain facts in their affidavits will sometimes be telling the truth. When the testimony is truthful and the officer actually had probable cause for the search, is there any point in deterring future carelessness in the warrant application process?

Although categorical rules either allowing or prohibiting the use of suppression hearing testimony to prove good faith are simple and easy to apply, I argue that an intermediate approach is more faithful to Leon and to the policies that underlie the Fourth Amendment's warrant requirement. In my view, information known to the affiant officer but never presented to the magistrate can establish the officer's good faith only where the omission resulted from a reasonable mistake in preparing the warrant application and the officer's knowledge of the information at the time of the warrant application is proven by clear and convincing evidence.

The argument is developed as follows. Part II briefly explains the historical development and rationale of the Leon good faith exception, then explores some of Leon's shortcomings by using Meir Dan-Cohen's model of "acoustic separation." Part III surveys the case law addressing the question whether an affiant officer's suppression hearing testimony about information omitted from the warrant application can establish the officer's good faith. It also explains why, contrary to the reasoning of some courts, this question is not answered by the many cases holding that particularity defects in a warrant can be cured by the executing officer's personal knowledge of the place to be searched.

To answer any question, one must first frame it properly. In Part IV, I show that although Leon does not directly answer the question of whether information not presented to the magistrate can establish an

5. See infra Part III. A-B.

6. Meir Dan-Cohen, Decision Rules and Conduct Rules: On Acoustic Separation in Criminal Law, 97 HARV. L. REV. 625 (1984). 
officer's good faith, it does show what the right question is. The proper question for good-faith purposes is whether, considering the totality of the circumstances known to the officer at the time of the warrant application, the officer had an objectively reasonable belief that the warrant was properly issued. Once the question is posed in this way, it is tempting to assume that information not presented to the magistrate can never be relevant to the officer's good faith because the propriety of the magistrate's decision to issue the warrant rests solely on the information presented to the magistrate. That conclusion is too quick, however, for it ignores the possibility that because of a mistake in filling out the warrant application, the officer was unaware of any gap between what he presented to the magistrate and what he actually knew. If this kind of mistake can be objectively reasonable, the officer could be said to have had an objectively reasonable belief that the warrant was properly issued because he reasonably believed that his entire case for probable cause had been presented to the magistrate. The propriety of using suppression hearing testimony to establish the officer's good faith under Leon turns out, then, to depend primarily on the question of whether there can be such a thing as an "objectively reasonable mistake" in the warrant application process. In light of this understanding of the inquiry, Part V presents a typology of cases illustrating the various kinds of mistakes that officers can make in the warrant application process and discusses several different ways to draw the line between those errors in the warrant application process that can be "forgiven" under Leon and those that cannot.

Finally, Part VI identifies and analyzes the various possible rules that could govern the use of suppression hearing testimony under Leon. I begin by describing the various functions of the warrant requirement, and explain that there are two ways in which the warrant application process serves to protect privacy even when magistrates fail to perform their constitutional roles. ${ }^{7}$ First, the costs and discipline of the warrant application process tend to filter out some bad searches before the officer ever reaches the magistrate by leading officers to impose upon themselves a higher probable-cause standard for warrant searches than for warrantless searches. Second, warrants protect privacy by creating an ex ante record of the basis for the search, thus making it more difficult for police to commit perjury in warrant searches than in warrantless searches. I then evaluate the various possible rules regarding

7. Of course, the magistrate has made a significant error in every case in which the outcome turns on the application of Leon. 
suppression hearing testimony in terms of their effects on these variables. I conclude that, on balance, the best rule would permit the use of suppression hearing testimony to establish the officer's good faith only where the information supporting probable cause was omitted from the warrant application through a reasonable mistake in preparing the application and the officer's knowledge of the information at the time of the warrant application is proven by clear and convincing evidence.

\section{LEON AND ITS CRITICS}

\section{A. Development of the Good Faith Exception}

The path toward the Leon good faith exception ${ }^{8}$ began with the Supreme Court's 1974 decision in United States $v$. Calandra, ${ }^{9}$ which described the exclusionary rule as "a judicially created remedy designed to safeguard Fourth Amendment rights generally through its deterrent effect, rather than a personal constitutional right of the party aggrieved." 10 Calandra meant that violations of Fourth Amendment rights did not automatically warrant application of the exclusionary remedy. Instead, the scope of the exclusionary rule's application would be determined through balancing the rule's deterrence benefits against the costs of exclusion. ${ }^{11}$ In the years following Calandra, the Court applied its new balancing approach to limit application of the exclusionary rule in a variety of contexts ${ }^{12}$ and seemed ready to adopt a

8. The historical development of the good faith exception has been traced with thoroughness and skill by others. See, e.g., Donald Dripps, Living with Leon, 95 YALE L.J. 906, 908-18 (1986) (recounting the arc of cases from Calandra to Leon); Elizabeth Phillips Marsh, On Rollercoasters, Submarines, and Judicial Shipwrecks: Acoustic Separation and the Good Faith Exception to the Fourth Amendment Exclusionary Rule, 1989 U. ILL. L. REV. 941, 958-65 (1989) (discussing cases from Calandra to Leon); Craig D. Uchida \& Timothy S. Bynum, Search Warrants, Motions to Suppress and "Lost Cases:" The Effects of the Exclusionary Rule in Seven Jurisdictions, 81 J. CRIM. L. \& CRIMINOLOGY 1034, 1036-41 (1991) (providing historical survey of the Supreme Court's case law regarding the exclusionary rule); Silas Wasserstrom \& William J. Mertens, The Exclusionary Rule on the Scaffold: But Was It a Fair Trial?, 22 AM. CRIM. L. REV. 85, 94-102 (1984) (discussing Gates and Leon). Accordingly, my treatment will be brief. For background on the general pre-Leon debate about the merits of a good faith exception to the exclusionary rule, see generally 1 WAYNE $R$. LaFAVE, SEARCH and Seizure: A TREATISE ON THE FouRTh AMENDMENT $\S 1.2$ (4th ed. 2002); Gerald G. Ashdown, Good Faith, the Exclusionary Remedy, and Rule-Oriented Adjudication in the Criminal Process, 24 WM. \& MARY L. REV. 335 (1983); William J. Mertens \& Silas Wasserstrom, The Good Faith Exception to the Exclusionary Rule: Deregulating the Police and Derailing the Law, 70 GEO. L.J. 365 (1981).

9. 414 U.S. 338 (1974).

10. Id. at 348 .

11. Id. at 348-52.

12. See United States v. Payner, 447 U.S. 727, 734 (1980) (holding that illegally seized evidence may be used in the prosecution's case in chief against persons not targeted by the search); 
good faith exception to the exclusionary rule in Illinois v. Gates. ${ }^{13}$ Instead, the Court held that the challenged affidavit had established probable cause for the search. ${ }^{14}$ In the process, the Court weakened the probable-cause standard in important ways. First, the Court made it easier for police to rely on informants' tips by abandoning the twopronged test it had adopted in Aguilar v. Texas ${ }^{15}$ and Spinelli v. United States. ${ }^{16}$ The Aguilar-Spinelli test had required officers to establish both the informant's "credibility" and his "basis of knowledge"-a failure in either prong meant the absence of probable cause. ${ }^{17}$ Under Gates, however, the two prongs of credibility and basis of knowledge became merely factors that the magistrate must consider in determining whether the "totality of circumstances" indicates a "fair probability" that evidence will be found in the place to be searched. ${ }^{18}$ In addition, the Court emphasized that reviewing courts should give significant deference to a magistrate's probable-cause determination, asking only whether the magistrate had a "'substantial basis for ... [concluding]' that probable cause existed." 19 As has often been pointed out, Gates's general dilution of the probable-cause standard arguably made the creation of a good faith exception unnecessary. ${ }^{20}$ If a magistrate lacked even a "substantial

United States v. Havens, 446 U.S. 620, 627-28 (1980) (holding that illegally seized evidence can be used for witness impeachment in criminal trials); Rakas v. Illinois, 439 U.S. 128, 134 (1978) (holding that the exclusionary rule only provides protection to defendants whose Fourth Amendment rights have been violated); Stone v. Powell, 428 U.S. 465, 494-95 (1976) (holding that illegally seized evidence can be used against defendants petitioning for federal habeas corpus); United States v. Janis, 428 U.S. 433, 454 (1976) (holding that illegally seized evidence can be used in civil proceedings).

13. 462 U.S. 213 (1983).

14. Id. at 246 .

15. 378 U.S. $108(1964)$.

16. 393 U.S. 410 (1969).

17. For discussion of the Aguilar-Spinelli approach to informants' tips, the transition to Gates, and the implications of that transition, see generally 2 LAFAVE, supra note $8, \S 3.3$.

18. Gates, 462 U.S. at 233,238 . The Court also emphasized the "fluid," "practical," and "nontechnical" nature of probable-cause judgments. Id. at 231-32.

19. Id. at 238-39 (quoting Jones v. United States, 362 U.S. 257, 271 (1960)). While review of magistrate probable-cause determinations had never been de novo, this aspect of Gates marked a significant increase in the degree of deference applied by reviewing courts. See Albert Alschuler, "Close Enough for Government Work": The Exclusionary Rule After Leon, 1984 SUP. CT. REV. 309, 322-23 \& n.50 (1984).

20. Yale Kamisar may have been the first to make this point. Writing before the Leon decision, he asked, "[h]ow could the officer have had a 'reasonable, good faith' belief that probable cause existed if it turns out that the totality of the circumstances did not add up to even a "substantial chance of criminal activity'?" Yale Kamisar, Gates, 'Probable Cause,' 'Good Faith, ' and Beyond, 69 IOWA L. REV. 551, 588-89 (1984). Justice Brennan made the same point in his Leon dissent, writing that the Gates and Leon standards overlap so completely that "it is unlikely that a warrant could be found invalid under Gates and yet the police reliance upon it could be seen as objectively 
basis" under the "totality of the circumstances" for finding a "fair probability" that a search would yield evidence, it is not easy to see how an officer could still have had a reasonable good-faith belief that the warrant was valid. Nevertheless, the Court took the further step of creating a general good faith exception for warrant searches in United States v. Leon ${ }^{21}$ and Massachusetts v. Sheppard. ${ }^{22}$

Echoing the balancing approach adopted in Calandra, Justice White's opinion in Leon began by explaining that when police have acted in reasonable reliance on a subsequently invalidated warrant, application of the exclusionary rule depends on weighing the costs of exclusion (i.e., the loss of "inherently trustworthy tangible evidence" from the prosecution's case in chief) against its possible benefits in deterring Fourth Amendment violations. ${ }^{23}$ The Court then argued for Leon's central claim: that courts weighing the benefits of exclusion should focus exclusively on deterrence of law enforcement officials. ${ }^{24}$ Possible effects on the conduct of magistrates were irrelevant, the Court said, for three reasons. First, the exclusionary rule was designed "to deter police misconduct rather than to punish the errors of judges and magistrates." 25 Second, there was no evidence that judges and magistrates were "inclined to ignore or subvert the Fourth

reasonable; otherwise, we would have to entertain the mind-boggling concept of objectively reasonable reliance upon an objectively unreasonable warrant." United States v. Leon, 468 U.S. 897, 958-59 (1984) (Brennan, J., dissenting). For additional commentary along the same lines, see 1 LAFAVE, supra note $8, \S 1.3(\mathrm{f})$, at 93-102; Alschuler, supra note 19, at 323-24; Dripps, supra note 8, at 912. The claim that Leon added nothing to Gates is exaggerated in one respect, of course. As Professor LaFave points out, Leon sweeps more broadly than Gates because it applies to facial challenges to warrant validity as well as to challenges based on probable cause. 1 LAFAVE, supra note $8, \S 1.3(\mathrm{f})$, at 95 . But at least in the context of probable-cause challenges, the argument that there can be no real gap between the Gates and Leon standards is powerful. Nevertheless, most courts appear to see such a gap and grant officers a measure of deference beyond that extended to magistrates. See, e.g., United States v. Bynum, 293 F.3d 192, 195 (4th Cir. 2002) (stating that Leon's "so lacking in indicia of probable cause as to render official belief in its existence entirely unreasonable" standard requires "a less demanding showing than the 'substantial basis' threshold required to prove the existence of probable cause in the first place"); United States v. Tuter, 240 F.3d 1292, 1298 (10th Cir. 2001) (holding that the magistrate lacked a substantial basis for finding probable cause under Gates but admitting evidence because the affidavit contained sufficient indicia of probable cause to establish the officer's good faith under Leon). But cf. People v. Leftwich, 869 P.2d 1260, 1271 n.12 (Colo. 1994) (stating that "in the vast majority of cases," courts finding no "substantial basis" for concluding that probable cause existed will also refuse to apply the good faith exception).

21. 468 U.S. 897.

22. 468 U.S. 981 (1984).

23. Leon, 468 U.S. at $906-07$.

24. Id. at 918 .

25. Id. at 916 . 
Amendment." 26 Third, and most crucially, the Court argued that there was no reason to think that exclusion would deter magistrates from issuing invalid warrants because magistrates are "not adjuncts to the law enforcement team" and "have no stake in the outcome of particular criminal prosecutions." 27 If exclusion had no effect on magistrates, the Court continued, it could only be justified by its ability to "alter the behavior of individual law enforcement officers or the policies of their departments. $" 28$

With this key premise in hand, the Court moved quickly toward the conclusion that suppressing the fruits of warrant searches will rarely further the deterrent purposes of the exclusionary rule. ${ }^{29}$ Officers can normally rely on a magistrate's probable-cause determination because it is "the magistrate's responsibility to determine whether the officer's allegations establish probable cause and, if so, to issue a warrant comporting in form with the requirements of the Fourth Amendment." ${ }^{30}$ Excluding evidence when the magistrate's determination is later judged faulty is "[p]enalizing the officer for the magistrate's error, rather than his own," and therefore "cannot logically contribute to the deterrence of Fourth Amendment violations." 31 The Court insisted, however, that the officer's reliance on the magistrate's judgment must be "objectively reasonable" 32 - the officer's contention that he subjectively believed himself to be acting in accordance with the Fourth Amendment would not be enough to establish his "good faith." 33 This objective approach was necessary both to eliminate the waste of judicial resources on "expedition[s] into the minds of police officers" 34 and to preserve incentives for police departments to equip their officers with a "reasonable knowledge of what the law prohibits.",35

Leon's good faith exception is broad but not boundless. The Court recognized that suppression might still be ordered on a case-by-case basis in circumstances where "a reasonably well-trained officer would have known that the search was illegal despite the magistrate's 
authorization." ${ }^{36}$ The Court listed four such circumstances, which I will refer to as the four exceptions to Leon's good-faith rule. ${ }^{37}$ Evidence must still be excluded under Leon if:

(1) the magistrate was "misled by information in an affidavit that the affiant knew was false or would have known was false except for his reckless disregard of the truth;",38

(2) the magistrate "wholly abandoned his judicial role in the manner condemned in Lo-Ji Sales, Inc. v. New York" ${ }^{39}$ (i.e., acted as a mere rubber stamp for the police); ${ }^{40}$

(3) the warrant was based on an affidavit "so lacking in indicia of probable cause as to render official belief in its existence entirely unreasonable;" $" 41$ or

(4) the warrant was "so facially deficient-i.e., in failing to particularize the place to be searched or the things to be seizedthat the executing officers" could not reasonably have thought it was valid. ${ }^{42}$

Under this framework, defendants attempt to defeat application of the good faith exception by proving that one or more of these exceptions applies. $^{43}$ Leon itself concerned the third exception, which is probably the most frequently litigated of the four. ${ }^{44}$ The Court easily concluded

36. Id. at 922 n.23.

37. It is unclear whether the Court meant for these exceptions to be exhaustive. See generally Abraham S. Goldstein, The Search Warrant, the Magistrate, and Judicial Review, 62 N.Y.U. L. REV. 1173, 1204-05 (1987); Kevin Jon Heller \& John Paul Reichmuth, Lying in Wait for the Good Faith Exception, THE CHAMPION, Feb. 22, 1998, at 53-54; Robert C. Gleason, Note, Application Problems Arising from the Good Faith Exception to the Exclusionary Rule, 28 WM. \& MARY L. REV. 743, 758-60 (1987).

38. Leon, 468 U.S. at 923 .

39. 442 U.S. 319 (1979). In Lo-Ji Sales, a magistrate judge approved a warrant for the search of an obscene bookstore and then accompanied officers to the scene to assist in the execution of the search. Id. at 319 .

40. Leon, 468 U.S. at 923.

41. Id. (citing Brown v. Illinois, 422 U.S. 590, 610-11 (1975) (Powell, J., concurring in part)).

42. Id.

43. To be more precise, the defense defines the shape of good-faith litigation by attempting to bring the case within one of the exceptions to Leon. Ultimately, however, the prosecution bears the burden of proving application of the good faith exception by a preponderance of the evidence. See United States v. Gant, 759 F.2d 484, 487-88 (5th Cir. 1985) (holding that once the defendant has proven that the warrant was not based on probable cause, the government must prove the applicability of the good faith exception, but noting that often the issue of burden of proof will have "little significance" because "the determination of good faith will ordinarily depend on an examination of the affidavit by the reviewing court"); State v. Mendoza, 748 P.2d 181, 186 (Utah 1987) (stating that under Leon the government must prove that the good faith exception applies).

44. See 1 LAFAVE, supra note $8, \S 1.3(\mathrm{f})$, at 92. 
that the probable-cause showing in the warrant application was sufficiently robust to make the officer's reliance on the warrant objectively reasonable. $^{45}$ In Leon's companion case, Massachusetts $v$. Sheppard, the Court applied the good faith exception to cure a particularity defect because "the officers reasonably believed that the search they conducted was authorized by a valid warrant., ${ }^{, 46}$

In the years since Leon, several additional Supreme Court decisions have both clarified and expanded the scope of the good faith exception. In Malley v. Briggs, ${ }^{47}$ the Court held that the "same standard of objective reasonableness" ${ }^{\prime \prime 8}$ applied in Leon determined the scope of an officer's qualified immunity from liability in a $\S 1983^{49}$ claim. ${ }^{50}$ Significantly, the Court squarely rejected the argument that an officer's reliance on a magistrate's probable-cause determination is always objectively reasonable. Although the magistrates in an ideal system would always disapprove inadequate warrant applications, the Court wryly noted that

45. Leon, 468 U.S. at 926 . This result is hardly surprising because, as Justice Stevens pointed out in his dissent, the affidavit likely established probable cause for the search under the Court's newly adopted standard in Gates. Id. at 961 (Stevens, J., dissenting).

46. 468 U.S. 981, 988 (1984). In Sheppard, the affiant officer sought a warrant to search for evidence in a murder case, but was unable to find the proper forms and therefore completed the warrant application using a form designed for dng searches. The officer alerted the magistrate that changes would need to be made to the wording of the warrant, and the magistrate assured the officer that he would make the necessary changes. The magistrate then made some changes to the form and returned it to the officer. Unfortunately, the magistrate had not crossed out the portion of the warrant that authorized a search for controlled substances. Id. at 985-86. As a result, the warrant authorized a search significantly broader than the probable-cause showing in the affidavit. Nonetheless, the Court applied Leon because the affiant officer had executed the search in the objectively reasonable belief that the warrant was valid. Id. at 989-90. It was objectively reasonable, the Court said, for the officer to rely on the magistrate's assurances that he had made the necessary alterations to the warrant. Id.

As Professor LaFave points out, Sheppard did not involve the usual scenario litigated under the fourth Leon exception. I LAFAVE, supra note $8, \S 1.3(\mathrm{f})$, at 87 . Ordinarily, officers have relied on a very broad description of the things to be seized by searching to the full extent of the warrant. The question is then whether the warrant was so obviously lacking in particularity that the officers should have recognized that the search was unconstitutional despite the magistrate's authorization. In Sheppard, the officers restricted the scope of their search to the items listed in the affidavit because they mistakenly assumed that the warrant authorized the search they had requested.

47. 475 U.S. 335 (1986).

48. An officer is entitled to qualified immunity, the Court said, unless the warrant application "is so lacking in indicia of probable cause as to render official belief in its existence unreasonable." Id. at 344-45 (citing Leon, 468 U.S. at 923 ).

49. 42 U.S.C. $\$ 1983$ (1996) (creating a damages remedy for violations of constitutional rights by government officials acting "under color of law").

50. Malley, 475 U.S. at 344 . Interestingly, the Court reasoned as though the scope of immunity under $\S 1983$ ought to be at least as wide, and possibly wider, than the scope of the exclusionary rule. As Professor Kamisar points out, however, there are many instances where officers ought to enjoy qualified immunity even though exclusion would be appropriate. Kamisar, supra note 20, at 575-76 (urging that police officers should sometimes be permitted to act upon anonymous tips without losing qualified immunity even when the fruits of the search are properly suppressed). 
"ours is not an ideal system" and that sometimes "a magistrate, working under docket pressures, will fail to perform as a magistrate should." is therefore reasonable, the Court said, to require an officer to minimize the danger of magistrate failure by "exercising reasonable professional judgment" about whether his affidavit establishes probable cause for an arrest or search. ${ }^{52}$ Where a reasonable officer would not have requested the warrant, the officer "cannot excuse his own default by pointing to the greater incompetence of the magistrate." 53

The Court expanded the good faith exception beyond the context of officer reliance on subsequently invalidated warrants in Illinois v. Krull ${ }^{54}$ and Arizona v. Evans. ${ }^{55}$ In Krull, the Court held that the exclusionary rule would no longer apply when officers acted in objectively reasonable reliance upon a statute later declared to be unconstitutional. ${ }^{56}$ As in Leon, the critical premise in Krull was that the sanction of exclusion could not be expected to have significant deterrent effects on legislators. ${ }^{57}$ In Evans, police had arrested and then searched the defendant in reliance upon an erroneous computer record that showed an outstanding warrant for his arrest on misdemeanor charges. ${ }^{58}$ In fact, the arrest warrant had been quashed seventeen days earlier but police computer records had not been updated because of a clerical error by either court clerks or police clerks. ${ }^{59}$ The Arizona Supreme Court had held that the evidence should be suppressed regardless of the source of the error, citing the dangers that negligently maintained computer records could pose to innocent citizens. ${ }^{60}$ The Supreme Court reversed and remanded, holding that Leon supports "a categorical exception to the exclusionary rule for clerical errors of court employees." ${ }^{.1}$ The Court

51. Malley, 475 U.S. at $345-46$.

52. Id. at 346 .

53. Id. at $346 \mathrm{n} .9$.

54. 480 U.S. 340 (1987).

55. 514 U.S. 1 (1995).

56. See Krull, 480 U.S. at 353.

57. Id. at 349-52. Justice O'Connor, joined by Justices Brennan, Marshall, and Stevens, dissented both on the historical ground that "[s]tatutes authorizing unreasonable searches were the core concern of the Framers of the Fourth Amendment" and the policy ground that legislators "by virtue of their political role are more often subjected to political pressures that may threaten Fourth Amendment values than are judicial officers." Id. at 362, 365-66 (O'Connor, J., dissenting).

58. 514 U.S. at 4 . Because the evidence the defendant sought to suppress was discovered during a search incident to his arrest, the suppression decision turned on the validity of the initial arrest. Id. at 6.

59. Id. at 4 .

60. State v. Evans, 866 P.2d 869, 871-74 (Ariz. 1994), rev'd, 514 U.S. 1 (1995).

61. Evans, 514 U.S. at 16 . The remand, which did not produce a reported decision, was needed 
reasoned that court employees, like magistrates, were "not adjuncts to the law enforcement team" and therefore were unlikely to be spurred to more accurate recordkeeping by the prospect of exclusion. ${ }^{62}$ The Court did not decide whether Leon would apply if police clerks, rather than court clerks, were responsible for the error. ${ }^{63}$ Several courts, however, have read the decision to imply that Leon should not apply to clerical errors by police department personnel. ${ }^{64}$

\section{B. The Trouble With Leon}

Leon and its progeny, then, have established that application of the exclusionary rule depends on whether suppression will deter Fourth Amendment violations enough to justify the exclusion of probative evidence. In answering this question, the Court has categorically declared that magistrates, legislators, and court personnel are so unlikely to be influenced by the prospect of suppression that the exclusionary rule should not apply when their mistakes lead to Fourth Amendment violations. In contrast, police officers (and, probably, other members of the law enforcement team) can be influenced by the prospect of exclusion. Even so, the Court has made clear that exclusion will rarely be appropriate when officers rely on the judgment of a neutral and detached magistrate.

to resolve the factual question of whether court clerks or police clerks were responsible for the faulty computer record.

62. Id. at 15. See also United States v. Santa, 180 F.3d 20, 30 (2d Cir. 1999) (applying Evans despite history of repeated errors by court employees because Evans turns not "on the particular type or magnitude of the error, but on the identity of the individuals responsible for the error").

63. Evans, 514 U.S. at 16 n.5.

64. See United States v. Shareef, 100 F.3d 1491, 1502-03 (10th Cir. 1996) (stating that the exclusionary rule applies when a police dispatcher's error leads to a Fourth Amendment violation); Hoay v. State, 71 S.W.3d 573, 577 (Ark. 2002) (stating that the exclusionary rule "should apply equally to defective recordkeeping by law enforcement"); People v. Willis, 46 P.3d 898, 912-13 (Cal. 2002) (applying the exclusionary rule where a data entry clerk whose job was to assist parole officers in carrying out law enforcement functions made a clerical error); Shadler v. State, 761 So. 2d 279, 284-85 (Fla. 2000) (applying the exclusionary rule where a Fourth Amendment violation resulted from police reliance on an error by a state driver's license division employee because regular police reliance on driver's license records makes such records "a vital part of the law enforcement infrastructure"); State v. White, 660 So. 2d 664, 667-68 (Fla. 1995) (applying the exclusionary rule because "police negligence" caused inaccuracy in computer records). It is clear, in any event, that if the good faith exception applies to clerical errors made by police personnel, it must be for different reasons than those given in Evans. Police clerks are, on any understanding, "adjuncts to the law enforcement team" and therefore should be subject to the deterrent influences of the exclusionary rule. 
After two decades of experience with Leon, courts have apparently gotten the message. Indeed, the Leon good faith exception to the exclusionary rule might be more aptly termed the good-faith "inclusionary rule" for warrant searches. ${ }^{65}$ Though some states have refused to follow Leon in interpreting their own constitutions, ${ }^{66}$ courts applying Leon rarely exclude evidence when police take the trouble to obtain a warrant. ${ }^{67}$ With Leon's blessing ${ }^{68}$ courts often proceed directly to the good-faith inquiry without any consideration of the probable-cause question. $^{69}$ Though suppression motions are still granted under Leon, ${ }^{70}$

65. Carol S. Steiker, Counter-Revolution in Constitutional Criminal Procedure? Two Audiences, Two Answers, 94 MICH. L. REV. 2466, 2469 (1996).

66. See People v. Goldston, 682 N.W.2d 479, 499 n.2 (Mich. 2004) (Cavanagh, J., dissenting) (listing cases); John E. Theuman, Annotation, State Constitutional Requirements as to Exclusion of Evidence Unlawfully Seized-Post-Leon Cases, 19 A.L.R. 5TH 470 (1994) (stating that perhaps as many as twenty-eight state courts have declined to follow Leon in interpreting their own constitutions).

67. I take this to be an uncontroversial assertion, at least as a characterization of the reported decisions applying Leon. To illustrate, I am aware of only one case in which the Fourth Circuit refused to apply Leon to admit the fruits of a warrant search. See United States v. Wilhelm, 80 F.3d 116,121 (4th Cir. 1996) (refusing to apply the good faith exception where the officer submitted a "bare-bones" affidavit). What is less clear is whether Leon has significantly reduced the success rate of suppression motions at the trial court level. An early effort to measure the empirical effects of Leon found no significant effect on either police practices regarding search warrants or the frequency or success rate of suppression motions. Craig D. Uchida et al., Acting in Good Faith: The Effects of United States v. Leon on the Police and Courts, 30 ARIZ. L. REV. 467, 494 (1988). The force of this conclusion is limited, however, because the study was conducted only shortly after Leon and therefore could not speak authoritatively to the lasting effects of the decision. Id. at 474, 494. Strikingly, the conclusion that Leon had little initial impact on suppression motions mainly rests on evidence that motions to suppress in search warrant cases were overwhelmingly likely to fail both before and after Leon. Id. at 492-93.

68. See Leon, 468 U.S. at 925 (stating that reviewing courts can "exercise an informed discretion" in rejecting some suppression motions "by turning immediately to a consideration of the officers' good faith").

69. See, e.g., United States v. Beckett, 321 F.3d 26, 31-32 (1st Cir. 2003); United States v. Martin, 297 F.3d 1308, 1315-16 (11th Cir. 2002); United States v. Bynum, 293 F.3d 192, 194-95 (4th Cir. 2002). But cf. United States v. Dahlman, 13 F.3d 1391, 1397-98 (10th Cir. 1993) (stating that under Leon the "preferred sequence" is to address Fourth Amendment issues before addressing good faith because a contrary course enables officers to repeat the same mistakes with impunity); Anzualda v. Commonwealth, 607 S.E.2d 749, 754 n.3 (Va. Ct. App. 2005) (en banc) (electing to decide the issue of probable cause first because "if we repeatedly fail to address the threshold question of probable cause, we will continue to neglect our duty to adequately educate our magistrates and to provide them with discrete legal guidelines, concomitantly reducing their role in the issuance of warrants to little more than that of a rubber stamp"). Commentators agree that courts commonly bypass questions of probable cause and proceed directly to the good-faith inquiry, but they disagree about whether this practice has had a tendency to inhibit the development of substantive Fourth Amendment law. Compare Zack Bray, Comment, Appellate Review and the Exclusionary Rule, 113 YALE L.J. 1143, 1146 (2004) (documenting and criticizing tendency of many courts to proceed directly to the good-faith inquiry), and Joan Greenberg Levenson, Comment, The Good Faith Exception: Should It Enable Courts to Avoid Explication of Underlying Fourth Amendment Issues?, 52 BROOK. L. REV. 799, 818-27 (1986) (criticizing Leon for allowing courts to adjudicate the good-faith issue without addressing the underlying issue of probable cause), with Sean 


\section{courts have sometimes construed the four exceptions to the Leon good- faith rule in grudging fashion. ${ }^{71}$}

Leon and its rationale, of course, have been challenged on many levels by both dissenting Justices and their academic supporters. Among the most prominent criticisms ${ }^{72}$ are the following: First, Leon is wrong to treat the exclusionary rule as a judicially created remedy meant to deter Fourth Amendment violations rather than a personal right grounded in the Constitution. ${ }^{73}$ Second, Leon fails to treat the Fourth Amendment as

R. O'Brien, Note, United States v. Leon and the Freezing of the Fourth Amendment, 68 N.Y.U. L. REV. 1305, 1336 (1993) (arguing that even after Leon, the exclusionary rule still adequately serves to prompt judicial development of Fourth Amendment doctrine).

70. See, e.g., United States v. Herron, 215 F.3d 812, 815 (8th Cir. 2000) (holding that the good faith exception did not apply where the affidavit's only evidence that the defendant was growing marijuana was two prior convictions for marijuana cultivation and observations that the defendant's relatives were growing marijuana at a nearby farm); United States v. Weaver, 99 F.3d 1372, $1377-$ 78 (6th Cir. 1996) (holding that the good faith exception did not apply where the affidavit was based almost entirely upon hearsay and lacked particularized incriminating facts); State v. Weston, 494 S.E.2d 801, 804 (S.C. 1997) (holding that the good faith exception did not apply where the affidavit "lacked any indicia of probable cause").

71. See generally Dripps, supra note 8, at 931 (criticizing State v. Wood, 457 So. 2d 206 (La. Ct. App. 1984), as a misapplication of Leon); David Clark Esseks, Note, Errors in Good Faith: The Leon Exception Six Years Later, 89 MiCH. L. REV. 625, 635-38 (1990) (surveying cases where Leon was used to admit evidence that should have been excluded). It must be acknowledged, however, that one still finds cases where courts set the bar of "reasonableness" very high. See, e.g., People v. Miller 75 P.3d 1108, 1115-16 (Colo. 2003) (en banc) (concluding, over a strong dissent and in the face of much contrary authority, that Leon did not apply because any reasonable officer would have recognized that a one-month-old observation of methamphetamine manufacturing in a home was too stale to establish probable cause for search). Courts sometimes also fail to construe warrants in the "common sense and realistic fashion" demanded by United States $v$. Ventresca, 380 U.S. 102, 108 (1965). See, e.g., State v. Koen, 113 P.3d 675, 680-83 (Alaska Ct. App. 2005) (concluding that the affidavit totally failed to establish a nexus between the place to be searched and the evidence to be sought despite persuasive dissent arguing that nexus could readily be inferred from the contents of the affidavit).

72. The list that follows is not meant to be exhaustive, and its ordering is not meant to reflect any position on which criticisms are the most important or persuasive. Though academic commentary discussing Leon has largely been critical, the decision has had its defenders. See, e.g., Matthew H. Lembke, Note, The Role of Police Culpability in Leon and Youngblood, 76 VA. L. REV. $1213,1232-35$ (1990) (stating that "[o]bjective good faith is ... a perfectly appropriate and desirable standard for application of the exclusionary rule," but cautioning that "the good faith exception can only function as intended if a meaningful measure of police good faith is established"). Donald Dripps has offered a more qualified defense of Leon's result, if not its reasoning or rationale. See Dripps, supra note 8, at $931-33$ (arguing that, if properly interpreted, Leon would not undermine the integrity of the warrant process).

73. See Leon, 468 U.S. at 931-35 (Brennan, J., dissenting) (arguing that the Fourth Amendment "comprises a personal right to exclude all evidence secured by means of unreasonable searches and seizures"); Yale Kamisar, Does (Did) (Should) the Exclusionary Rule Rest on a 'Principled Basis' Rather Than an 'Empirical Proposition'?, 16 CREIGHTON L. REV. 565, 569-71 (1983) (same); Thomas S. Shrock \& Robert C. Welsh, Up from Calandra: The Exclusionary Rule as a Constitutional Requirement, 59 MINN. L. REV. 251, 289-307 (1974) (same). But see Dripps, supra note 8 , at 918-22 (arguing the opposing viewpoint). 
law by recognizing a class of constitutional violations for which no remedy of any kind is available. ${ }^{74}$ Third, Leon's cost-benefit analysis overstates the costs and understates the benefits of the exclusionary rule. ${ }^{75}$ Fourth, Leon is wrong to assume that the prospect of suppression affects only police officers and never magistrates ${ }^{76}$ (or legislators ${ }^{77}$ or court clerks ${ }^{78}$ ). Fifth, Leon leads both magistrates and officers to take the warrant application process less seriously. ${ }^{79}$ Sixth, Leon ignores the empirical literature suggesting that magistrate review of warrant applications is often cursory. ${ }^{80}$ Seventh, Leon is problematic because (together with Gates) it gives magistrates virtually unreviewable discretion in the issuance of warrants but does nothing to ensure that magistrates are up to the task of serving as the first-line guarantors of Fourth Amendment rights. ${ }^{81}$

74. 468 U.S. at 977 n.35 (Stevens, J., dissenting); Dripps, supra note 8, at 934 n.152. Dripps calls this the "jurisprudential objection" to Leon. Id. at 934-39.

75. 468 U.S. at 949-51 (Brennan, J., dissenting); 1 LAFAVE, supra note 8, § 1.3(c)-(d), at 6068. Cf. James B. White, Forgotten Points in the Exclusionary Rule Debate, $81 \mathrm{MICH}$. L. REV. 1273 , 1282 (1983) (arguing that by adopting the rhetoric of cost-benefit analysis, the Court misconceives its constitutional role and masks the true basis of its decisions because inquiry into the costs and benefits of exclusion "can never be performed in an adequate way").

76. Leon, 468 U.S. at 956 (Brennan, J., dissenting); Alschuler, supra note 19, at 351-56; Wasserstrom \& Mertens, Exclusionary Rule on the Scaffold, supra note 8, at 105-12.

77. Illinois v. Krull, 480 U.S. 340, 365-66 (1987) (O'Connor, J., dissenting); 1 LAFAVE, supra note $8, \S 1.3(\mathrm{~g})$, at 106 .

78. 1 LAFAVE, supra note $8, \S 1.8(\mathrm{e})$, at 308 .

79. 468 U.S. at 957-58 (Brennan, J., dissenting); id. at 974 (Stevens, J., dissenting). See generally Steiker, supra note 65, at 2543-48 (discussing the concern that police will not take Fourth Amendment requirements seriously if those requirements are not enforced through the exclusionary rule).

80. Goldstein, supra note 37, at 1184; George R. Nock, The Point of the Fourth Amendment and the Myth of Magisterial Discretion, 23 CONN. L. REV. 1, 11-13 (1990). Goldstein relies heavily on a study conducted in the early 1980s by the National Center for State Courts. R. VAN DUIZEND et. al., Nat'L CTR. For State CTS., The Search Warrant Process: Preconceptions, PERCEPTIONS, AND PRACTICES (1985) [hereinafter NCSC Study]. The study found, among other things, that proceedings before magistrates generally lasted only two to three minutes and that magistrates often failed to ask any questions despite the presence of "boilerplate" language in many warrant applications. Id. at 51-53. The NCSC Study remains the most comprehensive and authoritative empirical account of the search warrant process. For an account of preliminary findings from a more recent study, see Laurence A. Benner \& Charles T. Samarkos, Searching for Narcotics in San Diego: Preliminary Findings from the San Diego Search Warrant Project, 36 CAL. W. L. REV. 221 (2000).

81. See Goldstein, supra note 37, at 1207; Robert L. Misner, Limiting Leon: A Mistake of Law Analogy, 77 CRIM. L. \& CRIMINOLOGY 507, 538-44 (1986). There are, of course, some powerful arguments that the exclusionary rule is not a very effective mechanism for preventing Fourth Amendment violations in any event. See, e.g., Christopher Slobogin, Why Liberals Should Chuck the Exclusionary Rule, 1999 U. ILL. L. REV. 363, 368-400 (1999). Professor Slobogin recommends that an administrative damages remedy take the place of the exclusionary rule, a suggestion that has much to recommend it on the merits even if its political feasibility is doubtful. A major problem with the Court's approach under Leon, in contrast, is that it restricts the scope of the exclusionary remedy while putting nothing in its place. 
I am sympathetic to many, indeed most, of these criticisms. ${ }^{82}$ In particular, I reject Leon's assumption that whole classes of government actors are beyond-perhaps "above" would be the better word ${ }^{83}$ - being influenced by the prospect of suppression. Even within the balancing framework adopted by the Court, the proper question ought to be whether exclusion will reduce the overall level of Fourth Amendment violations by the state-not by particular classes of state actors. ${ }^{84}$ Yet adding to the many academic criticisms of Leon is not my purpose here. Instead, I deal with a much more limited question about the application of Leon within the framework established by the Supreme Court. Specifically, I address an issue courts sometimes face in deciding whether to apply the third Leon exception, which provides that suppression is still appropriate when an officer's affidavit is "so lacking in indicia of probable cause as to render official belief in its existence entirely unreasonable." "\$5 The issue is whether courts should apply the good faith exception on the basis of information supporting probable cause that was known to the affiant officer at the time of the warrant application but never shared with the magistrate. ${ }^{86}$

The troublesome nature of Leon and its implications for this issue can be illuminated through the use of the metaphor of "acoustic separation" developed by Professor Meir Dan-Cohen. ${ }^{87}$ As a heuristic

82. The only criticism I find doubtful is the claim that Leon errs by not treating the exclusion of illegally seized evidence as a personal constitutional right of the accused. For arguments regarding that issue, see sources cited supra note 73.

83. See Alschuler, supra note 19, at 357 (suggesting that Leon's approach demeans police officers by assuming they are generally less respectful of constitutional rights than judicial officers).

84. See Mertens \& Wasserstrom, Deregulating the Police, supra note 8, at 431 (stating that the proper inquiry is whether the exclusion of evidence will reduce future Fourth Amendment violations at an acceptable cost, not whether exclusion will deter police officers who act in good faith); see also Note, Exclusionary Rule: Good Faith Exception for Clerical Error, 109 HARV. L. REV. 131, 135 (1995) (arguing that "the purpose of the exclusionary rule should be to prevent all future Fourth Amendment violations, not just those violations that result from police disregard for constitutional rights"); cf. Arizona v. Evans, 514 U.S. 1,18 (1995) (Souter, J., concurring) (explaining that the spectre of computerized error in police work might eventually lead the Court to think of the exclusionary sanction as applying to "the government as a whole, not merely the police").

85. United States. v. Leon, 468 U.S. 897, 923 (1984) (quoting Brown v. Illinois, 422 U.S. 590, 610-11 (Powell, J., concurring in part)).

86. In the interest of brevity, I will often describe my topic as the question whether suppression hearing testimony can establish an officer's good faith under Leon. I should acknowledge that, at one level, the answer to the question may seem obvious. If one believes (as I do) that Leon was a mistake, one will naturally want to interpret the case as narrowly as possible. In this context, that would mean holding that suppression hearing testimony should never be allowed to establish an officer's good faith. This perspective, however, offers little help to courts obligated to follow Leon as the law of the land. While not turning a blind eye to the problems created by Leon, my project here is to work within its assumptions insofar as possible and to fashion a solution that makes sense for courts that (willingly or grudgingly) must follow Leon.

87. Dan-Cohen, supra note 6. 
device for explicating Bentham's distinction between "decision rules" (which guide officials in their efforts to apply the law) and "conduct rules" (which provide behavioral norms for the general public), DanCohen asks us to imagine a world consisting of two groups of people: (1) members of the general public who perform various actions and (2) officials who rule on the propriety of the public's actions. ${ }^{88}$ Each group occupies a separate, acoustically sealed chamber - hence the metaphor of acoustic separation. In a universe of acoustic separation, the law transmits separate normative messages to each group-neither group can hear the message intended for the other. ${ }^{89}$ The messages intended for and heard only by the general public are conduct rules, those heard only by the officials are decision rules. ${ }^{90}$ The real world, of course, is not one of acoustic separation: members of the general public sometimes "hear" the messages intended for officials and vice versa. ${ }^{91}$ This lack of acoustic separation can sometimes cause problems for the law's normative aims. For example, individuals who are familiar with decision rules may consider those rules in making choices about how to behave even when the law would prefer that they not do so. ${ }^{92}$

Dan-Cohen illustrates the point via the criminal defense of duress. Traditional debates about the appropriateness of the defense have portrayed the law as facing an irreconcilable conflict between the values of deterrence (arguing against recognizing the duress defense) and compassion or fairness (arguing for its recognition). ${ }^{93}$ As Dan-Cohen points out, however, this clash of values would not exist in a world of acoustic separation. ${ }^{94}$ In such a world, the duress defense would be a pure decision rule that would be "heard" only by officials and would therefore have no side effects that might tend to undermine the force of the conduct rules proscribing the various criminal offenses. ${ }^{95}$ Acoustic separation would "permit[] the law to maintain higher degrees of both deterrence and leniency than could otherwise coexist." 96 Indeed, acoustic separation is sometimes so normatively useful that the law seeks to mimic its effects by relying on existing "partial acoustic separation" (i.e., differences in the degrees to which messages are heard by different

\footnotetext{
88. Id. at 630 .

89. Id.

90. Id.

91. Id. at 631 .

92. Id at 632-34.

93. Id. at 633 .

94. Id.

95. Id. at 633-34

96. Id. at 665 .
} 
groups) and even engaging in "strategies of selective transmission" (i.e., methods of segregating the law's messages so as to "increase the probability that a certain normative message will reach only the constituency for which it is intended"). ${ }^{97}$ For example, Dan-Cohen argues that the notorious vagueness of the duress defense can be seen as a strategy of selective transmission through which the law attempts to partially duplicate the conditions of acoustic separation: "the indeterminacy of the standards makes it less likely that ordinary citizens will be able to rely on them with any degree of confidence." 98

Although Dan-Cohen developed the acoustic separation model in the context of discussing substantive criminal law and its conduct rules addressing the general public, the model can be easily extended to the context of criminal procedure. ${ }^{99}$ Adapting the model to that context, Fourth Amendment norms regarding such topics as the warrant requirement, probable cause, and reasonable suspicion are conduct rules telling police officers how they should conduct criminal investigations. The exclusionary rule and the Leon good faith exception are decision rules that tell judges how they should respond to police violations of the conduct rules. ${ }^{100}$ The traditional exclusionary rule, though applied by judges, also sent a clear normative message to officers: abide by the conduct rules or forfeit the use of any evidence you obtain. Indeed, the traditional exclusionary rule depended on a lack of acoustic separation for its effectiveness. Leon, on the other hand, is a rule that would work best in a world of acoustic separation. If one accepts the position that the exclusionary rule creates no rights in the accused and is merely a tool for modifying police behavior, it follows that in a world of acoustic separation there would never be a need to actually apply the exclusionary rule. Instead, police officers would hear only the conduct rules generated by the Fourth Amendment and the message that exclusion was the

97. Id. at 634-35. Dan-Cohen explains that these "strategies of selective transmission" need not have been consciously pursued - though, of course, they can be. Rather, they should be seen as the sort of "strategies without a strategist" discussed in much of Michel Foucalt's work. They are "social phenomena, patterns, and practices that look like (that is, are amenable to an illuminating interpretation as) tactics for promoting certain human interests or values." Id. at 635-36.

98. Id. at 640 .

99. Dan-Cohen noted that the model could be used in other contexts. Id. at $635 \mathrm{n} .21$. His suggestion has been heeded at least twice in discussions of criminal procedure. See Marsh, supra note 8, at 946-58 (using the acoustic separation model to analyze the good faith exception); Steiker, supra note 65 , at 2548-51 (discussing problems caused by acoustic separation between the two audiences for the Court's criminal procedure jurisprudence: law enforcement officials and the general public). Marsh's general concerns about Leon are similar to my own, though she does not discuss the question of whether Leon should allow information not communicated to the magistrate to establish the officer's good faith.

100. See Steiker, supra note 65 , at $2470,2534$. 
sanction for any violation. Accordingly, they would go on behaving as though Leon did not exist and the law could both have its cake (effective promotion of compliance with the Fourth Amendment) and eat it too (no windfalls to the guilty from the loss of probative evidence). ${ }^{101}$

The trouble is that although Leon would make perfect sense in the world described by the acoustic separation model, the assumptions of that model are especially inapt as a description of the world actually governed by Leon. This is so because police officers are highly attuned to the judicial rules governing their behavior. ${ }^{102}$ Indeed, some empirical work on police culture indicates that officers are likely to regard Fourth Amendment conduct rules as meaningless unless they believe that violations of those rules will be sanctioned. ${ }^{103}$ To the extent that officers do "overhear" the normative message of Leon, that message functions to undermine the seriousness of their adherence to the relevant conduct rules. This is evident even in the way the third Leon exception is formulated. Where officers about to submit a warrant application once asked themselves, "does the information in my affidavit establish probable cause for this search?," those who have heard and understood the message of Leon might ask, "could a well-trained officer reasonably believe that the information in my affidavit provides the magistrate with at least a substantial basis for finding probable cause?" The shift from

101. The text's portrait of Leon in a world of acoustic separation is misleading in one respect, as it does not do justice to the ways in which Leon is meant to encourage use of warrants by offering the "safe harbor" of deferential review once a warrant is obtained. See David A. Sklansky, QuasiAffirmative Rights in Constitutional Criminal Procedure, 88 VA. L. REV. 1229, 1247-48 (2002) (explaining how Leon can be viewed as a "pro-warrant" decision rather than simply as an "antiexclusionary rule" decision). There must be less than complete acoustic separation for this part of Leon's message to influence police officers.

102. Steiker, supra note 65, at 2534-37 (arguing that the relationship between Supreme Court decisions and the police is one of "very low acoustic separation").

103. According to Steiker, "[w]here the police 'hear' the Court's decision rules and thus are able to predict the likely legal consequences of their unconstitutional behavior, they may see little reason to continue to obey conduct rules that consistently are unenforced in criminal prosecutions." Id. at 2543. She also expresses concern that as Leon and similar doctrines adopted by the Rehnquist Court increase the gap between conduct rules and decision rules, some police officers will come to view the decision rules rather than the conduct rules as "the 'real' law." Id. at 2545. In support of these claims, Steiker points to a study based on police officer interviews by Professor Milton Loewenthal. Id. (citing Milton A. Loewenthal, Evaluating the Exclusionary Rule in Search and Seizure, 49 UMKC L. REV. 24, 29 (1980)). Professor Lowenthal found, for example, that most police officers interpreted Wolf $v$. Colorado, 338 U.S. 25 (1949), which declined to extend the federal Fourth Amendment exclusionary rule to the states, "as not having imposed any legal obligation on the police since, under that decision, the evidence would still be admissible no matter how it was obtained." Steiker, supra note 65, at 2545 (quoting Loewenthal, supra, at 29). For a similar perspective, see JEROME SKOLNICK, JUSTICE WITHOUT TRIAL: LAW ENFORCEMENT IN DEMOCRATIC SOCIETY 277 (3d. ed. 1994) (criticizing the Leon good faith exception partly on the ground that "[w]ithout an exclusionary rule, the Fourth Amendment has little meaning to police"). 
the first question to the second does not bode well for Fourth Amendment compliance. ${ }^{104}$

The possible "conduct side effects" of the Leon decisional rule in a world without acoustic separation have always been at the core of objections to Leon, starting with the dissents of Justices Brennan and Stevens. ${ }^{105}$ This way of describing the trouble with Leon also suggests a strategy for interpreting it. If Leon presupposes that officers acting in objective good faith cannot be deterred, Leon ought, insofar as possible, to be interpreted so it does not change the way police officers operate. In other words, it ought to be interpreted so as to utilize strategies of selective transmission to the greatest possible extent. ${ }^{106}$ To put things somewhat paradoxically, courts should apply Leon only in cases where police officials appear to have acted in just the way they would have acted without Leon. Where the officer appears to have relied on Leon in his approach to the warrant application process, Leon should not be available to save him. ${ }^{107}$ I develop these ideas more fully in Part VI. For now, I turn to a survey of the relevant case law.

104. Of course, the possible drop in the level of police self-scrutiny before submitting a warrant does not matter if the magistrate conducts a rigorous review. The problem is that magistrates do not always conduct this kind of review, and Leon does nothing to ensure that they will do so.

105. See United States v. Leon, 468 U.S. 897, 955 \& n.14, 957-58 (1984) (Brennan, J., dissenting) (arguing that Leon would reduce incentives for police training, would remove incentives for officers "to err on the side of constitutional behavior," and would result in magistrate shopping); id. at 975-76 (Stevens, J., dissenting) ("The Court's approach-which, in effect, encourages the police to seek a warrant even if they know the existence of probable cause is doubtful—can only lead to an increased number of constitutional violations."). Indeed, Justice Brennan's dissent also calls attention to the ways in which the good-faith "decision rule" will have unintended conduct side effects on magistrate behavior. See id. at 956 (Brennan, J., dissenting) (arguing that Leon tells magistrates they need not bother conducting a searching review of warrant applications "since their mistakes will from now on have virtually no consequence"). But see Dripps, supra note 8, at 929 (suggesting that any possible decrease that Leon might cause in magisterial scrutiny of warrant applications may be offset by "the possibility that other magistrates, knowing the likely unreviewability of their decisions, will scrutinize applications more carefully").

106. Of course, a self-conscious strategy of selective transmission can be seen as a kind of governmental deception and therefore raises moral questions, especially in light of the ideal that political processes should be transparent. Larger questions about the morality of this kind of deception are beyond the scope of this article. For Dan-Cohen's discussion, see Dan-Cohen, supra note 6, at 665-77. See also Larry Alexander \& Emily Sherwin, The Deceptive Nature of Rules, 142 U. PA. L. REV. 1191, 1192 (1994) (arguing that a degree of governmental deception is inevitable if society is to enjoy the many social benefits gained through the promulgation of "serious rules," rules that "dictate[] the course of action to be taken in all cases that fall within [their] terms").

107. Cf. Dan-Cohen, supra note 6, at 671 (noting that defenses such as duress "melt away as soon as one relies upon them. An individual who would not have committed an offense but for his knowledge of the existence of such a defense cannot, in most cases, avail himself of the defense"). 


\section{LEON AND SUPPRESSION HEARING TESTIMONY IN THE COURTS}

In the years since the Supreme Court decided Leon, only a relatively small number of federal and state courts have explicitly addressed the question of whether information known to the affiant but not communicated to the magistrate can establish the officer's good faith. ${ }^{108}$ Nearly all these courts have answered the question by taking a bright-line position. One line of authority, begun by the Eighth Circuit, appears to hold that evidence known to an officer but never submitted to a magistrate can always be used to establish the officer's good faith because the good-faith inquiry requires looking to the "totality of circumstances" known to the officer. ${ }^{109}$ The opposing line of cases, begun by the Ninth Circuit, takes the view that Leon never permits consideration of information known to the officer but not shared with the magistrate. ${ }^{110}$ Other federal circuits, federal district courts, and state courts have split between the Eighth and Ninth circuit views. A few opinions have hinted-correctly, in my view-that the Eighth and Ninth circuit views may be too extreme, but have failed to develop a comprehensive middle position.

\section{A. The Eighth Circuit View}

The Eighth Circuit's 1987 decision in United States v. Martin ${ }^{111}$ was the first to say that Leon allows courts to look beyond the face of the affidavit in assessing the officer's good faith. The majority opinion actually held that the affidavit's probable-cause showing was good enough to satisfy Leon, ${ }^{112}$ but then gratuitously observed that courts assessing an officer's good faith "can and must look to the totality of the circumstances including what [the officer] knew but did not include in

108. See infra Part III. A-B. Academic commentary prior to this Article has been very limited, consisting mainly of two student notes discussing the Eleventh Circuit's decision in United States $v$. Martin, 297 F.3d 1308 (11 th Cir. 2002). See infra note 119. In the latest edition of his search and seizure treatise, Professor LaFave suggests that the good-faith inquiry should not be extended to include information never presented to the magistrate at the time of the warrant application. 1 LAFAVE, supra note $8, \S 1.3(\mathrm{f})$, at $91-92$.

109. United States v. Martin, 833 F.2d 752, 755-56 (8th Cir. 1987). To be fair, I should observe that courts following the Eighth Circuit view have not explicitly said "always." Their pronouncements on the question, however, do not seem to include any exceptions.

110. United States v. Hove, 848 F.2d 137, 140 (9th Cir. 1988).

111. 833 F.2d 752 .

112. Id. at 755. For a more detailed discussion of the facts in Martin, see infra notes 269-82 and accompanying text. 
his affidavit." "113 A concurring opinion argued that the affidavit's probable-cause showing was too scanty to be saved by Leon, but agreed with the majority that "[d]eciding whether an officer acted in good faith requires an examination of the totality of the circumstances beyond the four corners of the affidavit."114 The concurring judge was willing to apply the good faith exception because " $[t]$ he facts known to [the officer] but omitted from the affidavit clearly were sufficient to justify a reasonable belief that probable cause existed."115 Neither the majority opinion nor the concurrence offered sustained arguments for its position; instead, the opinions simply cited proof texts ${ }^{116}$ from Leon and Anderson v. Creighton. ${ }^{17}$

Though Martin's decree that courts applying Leon "can and should" look to information never presented to the magistrate was dictum, the Eighth Circuit has consistently followed that dictum without engaging in any further analysis. ${ }^{118}$ The Eighth Circuit decisions following Martin typically bypass both the probable-cause determination and the question of whether the affidavit considered by itself would have been enough to establish the officer's good faith. Instead, they move directly to the conclusion that, considering the totality of the circumstances (including information known to the officer but never communicated to the magistrate), the officer acted in good faith. As a result, it is sometimes unclear whether resorting to materials outside the scope of the affidavit is genuinely necessary to the decisions.

The Eleventh Circuit adopted the Eighth Circuit's position in another case called United States v. Martin,${ }^{19}$ holding that "a reviewing court may look outside the four corners of the affidavit in determining whether an officer acted in good faith when relying upon an invalid warrant."120

113. Id. at 756 .

114. Id. at 757 (Lay, C.J., concurring).

115. Id.

116. Id. at 756 (majority opinion), 757 (Lay, C.J., concurring). For critical analysis of these textual arguments, see infra notes 168-73 and accompanying text

117. 483 U.S. 635 (1987).

118. See, e.g., United States v. Marion, 238 F.3d 965, 969 (8th Cir. 2001); United States v. Weeks, 160 F.3d 1210, 1212 (8th Cir. 1998); United States v. Johnson, 78 F.3d 1258, 1263 (8th Cir. 1996); United States v. Rugh, 968 F.2d 750, 753 (8th Cir. 1992); United States v. Simpkins, 914 F.2d 1054, 1057 (8th Cir. 1990).

119. 297 F.3d 1308 (11th Cir. 2002). For discussions of the Eleventh Circuit's Martin decision, see Pamela L. Coleman, Note, Beyond the Four Corners: Objective Good Faith Analysis or Subjective Erosion of Fourth Amendment Protections?, 54 MERCER L. REV. 1719 (2003); Recent Case, United States v. Martin: Eleventh Circuit Holds that Courts May Look Beyond the Text of a Warrant when Determining Whether an Officer Reasonably Relied Upon the Warrant, 116 HARV. L. REV. 1185 (2003).

120. Martin, 297 F.3d at 1309 . Though the quoted language seems clear enough, the Martin 
As with the Eighth Circuit's 1987 Martin decision, the court offered little argument in support of its position. Instead, it simply relied on the implications of its earlier decision in United States $v$. Taxacher ${ }^{121}$ and on the unfounded claim that "a majority of [the] circuits have taken into consideration facts outside the affidavit when determining whether the Leon good faith exception applies."122

opinion is puzzling in several respects. At one point in the opinion, the court concluded (implausibly, in my view) that "it was not entirely unreasonable for [the officer] to believe that what he wrote in the affidavit would be sufficient to support a finding of probable cause." Id. at 1315 (emphasis added). In fact, the court explicitly said that none of the four listed exceptions to the good-faith rule applied. Id. at 1318. The court could (and should) have stopped at this point; instead, it went on to consider "whether a reasonably well-trained officer would [have] know[n] that the warrant was illegal despite the magistrate's authorization." Id. (citing Leon, 468 U.S. at 922 n.23). This seems misguided. If we assume the four Leon exceptions are not meant to be exhaustive, a court might appropriately fall back on the quoted language if the defendant argued that the officer's reliance on the warrant was unreasonable in some way not captured by one of the four listed exceptions. But no such argument was offered in Martin, and thus the "extra stage" of the good-faith inquiry was unnecessary. $C f$. United States v. Carpenter, 360 F.3d 591, 599-600 (6th Cir. 2004) (en banc) (Gilman, J., concurring) (voicing similar criticisms of the Martin opinion), cert. denied, 543 U.S. 851 (2004). Because the Martin court only relied on information outside the affidavit in this final, redundant part of its opinion, one might even argue that the opinion's asserted holding was merely dictum. It has not, of course, been treated that way by the Eleventh Circuit. See United States v. Robinson, 336 F.3d 1293, 1297 (11th Cir. 2003) (stating "Martin held that the court "can look beyond the four corners of the affidavit" in assessing the officer's good faith).

Another odd feature of the Martin opinion is that it did not explicitly reject United States $v$. Hove, 848 F.2d 137 (9th Cir. 1988), the leading case supporting the proposition that courts should not look beyond the face of the affidavit in the good-faith inquiry. Instead, the Martin court distinguished Hove by claiming that the Hove affidavit, unlike the one in Martin, had lacked "any indicia of probable cause." Martin, 297 F.3d at 1319 n.11. This might be read to suggest that Eleventh Circuit courts should consider suppression hearing testimony only after initially deciding that the face of the affidavit is not "wholly lacking" in indicia of probable cause. In other words, the court could be suggesting that suppression hearing testimony can cure small deficiencies in the affidavit but not large ones-a suggestion that points (if vaguely) toward the position advocated in this Article. On the other hand, the language in the text of the opinion suggests no such limitation on the use of suppression hearing testimony to prove good faith. The matter is simply unclear, and so far the Eleventh Circuit cases citing Martin have provided no clarification.

121. 902 F.2d 867 (11th Cir. 1990).

122. Martin, 297 F.3d at 1319. In support of this claim, Martin cites United States v. Marion, 238 F.3d 965 (8th Cir. 2001); United States v. Danhauer, 229 F.3d 1002 (10th Cir. 2000); United States v. Procopio, 88 F.3d 21 (1st Cir. 1996); United States v. Gahagan, 865 F.2d 1490 (6th Cir. 1989); United States v. Owens, 848 F.2d 462 (4th Cir. 1988); and United States v. Word, No. 1P 99106-CR H/F, 2000 WL 724041 (S.D. Ind. May 31, 2000), aff'd, 1 F. App'x 491 (7th Cir. 2001). This listing of cases significantly overstates the authority supporting the court's position. Marion is an Eighth Circuit case, and Procopio arguably offers indirect support for the Martin result by implicitly suggesting that information not contained in the affidavit can sometimes be relevant to the good-faith inquiry. See infra notes 233-37 and accompanying text. The court's reliance on the other cases is misplaced. Danhauer's finding of good faith did not rest on appeals to information known to the officer but not shared with the magistrate. Gahagan and Owens are both cases in which courts ruled that a warrant's description of the place to be searched was sufficiently particular to satisfy the Fourth Amendment by relying in part on the executing officer's knowledge of the place to be searched. As I explain below, see infra notes 155-67 and accompanying text, these cases raise 
In addition to the Eighth and Eleventh circuits, federal district courts in Texas ${ }^{123}$ and Indiana, ${ }^{124}$ and state courts in Arkansas, ${ }^{125}$ Nebraska, ${ }^{126}$ and Kentucky ${ }^{127}$ have held that suppression hearing testimony can cure probable-cause deficiencies in the affidavit. Just as the Eighth Circuit's decision in Martin relied uncritically on citations to Anderson and Leon, these cases rely uncritically on citations to Martin.

\section{B. The Ninth Circuit View}

The Ninth Circuit's 1988 decision in United States v. Hove ${ }^{128}$ was the first to hold that Leon does not allow suppression hearing testimony

questions quite different from those raised by claims that Leon allows suppression hearing testimony to cure probable-cause defects in the affidavit. The Seventh Circuit's position is also far less clear than the Martin court suggests. Though the district court decision in Word did adopt the Eighth Circuit view, it did so as an altemative holding. The Seventh Circuit's per curiam, unpublished affirmance of the district court decision is brief and contains no discussion of this aspect of the district court's reasoning. Further, the affirmance of Word lacks precedential authority as an unpublished decision, and the Seventh Circuit more recently has rejected (albeit in dicta) the Eighth Circuit view in United States v. Koerth, 312 F.3d 862, 869, 871 (7th Cir. 2002). See infra notes 144-46 and accompanying text (discussing Koerth).

123. United States v. Dodd, 349 F. Supp. 2d 1039, 1050-51 (W.D. Tex. 2004). As in the Eleventh Circuit's Martin opinion, the court looked beyond the four comers of the affidavit only after concluding that the affidavit was substantial enough to support reasonable reliance. As a result, the court's adoption of the Eighth Circuit view was unnecessary to the result in the case and could arguably be treated as dictum..

124. Word, 2000 WL 724041. As explained above, this case has little or no weight as a precedent for the Eighth Circuit view. See supra note 122.

125. Moya v. State, 981 S.W.2d 521 (Ark. 1998).

126. State v. Edmonson, 598 N.W.2d 450, 461 (Neb. 1999). The Nebraska Supreme Court initially rejected the Eighth Circuit view in State v. Parmar, 437 N.W.2d 503 (Neb. 1989), but changed course ten years later in Edmonson. There, the officers initially presented the magistrate with an affidavit that relied heavily on a confidential informant's tip but provided no basis for the conclusory characterization of the informant as "reliable." The magistrate approved the initial warrant application, but before executing the warrant the officers returned to the same judge with a supplemental affidavit providing reasons why the informant should be regarded as reliable. Unfortunately, the magistrate erred by failing to rescind the original warrant and issue a new warrant that would have been based upon both the original and supplementary affidavits. Edmonson understandably concluded that the officers acted in good faith because they could not be expected to know that the supplementary affidavit would not cure the problems with the original affidavit. As Professor LaFave points out, the facts of Edmonson made it unnecessary for the court to overrule Parmar and adopt the Eighth Circuit view. 1 LAFAVE, supra note 8, §1.3(f), at 91-92 nn.111-12. Unlike the decisions in the Eighth and Eleventh Circuit's Martin cases, the crucial fact in Edmonson is that the officers did present all their evidence to the magistrate before they executed the search warrant.

127. Moore v. Commonwealth, 159 S.W.3d 325, 328 (Ky. 2005). As in some of the other cases, Moore appears to treat its agreement with the Eighth and Eleventh circuits as a holding, yet this part of the decision seems unnecessary because the court had already said that the affidavit contained enough indicia of probable cause to support reasonable reliance. $I d$.

128. 848 F.2d 137 (9th Cir. 1988). 
to cure probable-cause deficiencies in an affidavit. In Hove, the affidavit's probable-cause showing was too weak to support reasonable reliance because it contained nothing to establish the required nexus between criminal activity and the place to be searched. ${ }^{129}$ The affiant testified at the suppression hearing that he had recited the relevant facts to a stenographer in the course of preparing his affidavit but that the stenographer had failed to include them. ${ }^{130}$ The Ninth Circuit refused to apply the good faith exception on the basis of this testimony, holding that "Leon does not extend ... to allow the consideration of facts known only to an officer and not presented to a magistrate."131 This followed, the court said, from Leon's insistence that the test for good faith must be an objective one. ${ }^{132}$ The court further observed that officers who present "a colorable showing of probable cause" to a magistrate should be able to rely on the magistrate's decision, but that " $[t]$ o permit the total deficiency of the warrant and affidavit to be remedied by subsequent testimony concerning the subjective knowledge of the officer who sought the warrant would... unduly erode the protections of the fourth amendment."133

The Sixth Circuit recently joined the Ninth Circuit camp, holding in United States v. Laughton ${ }^{134}$ that "a determination of good-faith reliance, like a determination of probable cause, must be bound by the four corners of the affidavit." 135 The circuit's path to this position did not follow a straight line. A 2003 panel opinion in United States $v$. Carpenter ${ }^{136}$ found the affidavit "insufficient" to support good-faith reliance, but applied Leon anyway on the basis of information known to the officers but omitted from the warrant application. ${ }^{137}$ The Sixth Circuit vacated the panel opinion and granted an en banc rehearing to

129. Id. at $139-40$.

130. Id. at 139 .

131. Id. at 140 .

132. Id. (citing United States v. Leon, 468 U.S. 897, 923 (1984)).

133. Id. The Hove decision has been justifiably criticized for stating that the test of good faith is whether "reasonable jurists could disagree" about whether the affidavit established probable cause. See United States v. Taxacher, 902 F.2d 867, 871-72 (11th Cir. 1990) (rejecting the test used in Hove). Although the language relied upon in Hove comes from the Leon opinion, 468 U.S. at 926 , the Supreme Court clearly did not intend for that language to be used as an all-purpose "test" for good faith. This error, however, has no bearing on the correctness of the Hove court's position that information known to an officer but not presented to the magistrate is irrelevant to the Leon goodfaith inquiry.

134. 409 F.3d 744 (6th Cir. 2005).

135. Id. at 751 .

136. 317 F.3d 618 (6th Cir. 2003), vacated, 360 F.3d 591 (6th Cir. 2004) (en banc), cert. denied, 543 U.S. 851 (2004).

137. Id. at 624 . 
consider whether good faith could be established through facts not presented to the magistrate, but the en banc Carpenter opinion never resolved the issue because it held that the affidavit in the case was (after all) sufficiently substantial to support good-faith reliance. ${ }^{138}$ Though he agreed with this conclusion, Judge Gilman's concurring opinion vigorously championed the Ninth Circuit view by arguing that "[i]nformation tending to show the existence of probable cause that was not disclosed to the issuing magistrate cannot logically have any bearing on the reasonableness of the presenting officer's belief that the warrant was properly issued, as opposed to the officer's reasonable belief that probable cause existed for the search."139 In dissent, Judge Moore endorsed Judge Gilman's arguments and concluded that " $[\mathrm{k}]$ nowledge withheld, either by accident or through purposeful omission or misrepresentation, cannot resuscitate otherwise suppressible evidence." 140 With the decision in Laughton, the views advanced by Judges Gilman ${ }^{141}$ and Moore have now carried the day in the Sixth Circuit $^{142}$-at least for the present. ${ }^{143}$

The Seventh Circuit also has voiced agreement with the Ninth Circuit view, stating in United States v. Koerth ${ }^{144}$ that in conducting the good-faith inquiry it would "limit [its] inquiry to whether the officer could have reasonably believed that the materials presented to the magistrate judge (either in an affidavit or in some other respect such as testimony from the police officers) were sufficient to establish probable cause." 145 This language appears to be dictum, however, because the court admitted the contested evidence without reference to information withheld from the magistrate and therefore had no need to reach the

138. Carpenter, 360 F.3d at 597.

139. Id. at 598 (Gilman, J., concurring).

140. Id. at 601 (Moore, J., dissenting).

141. Interestingly, Judge Gilman dissented in Laughton. Though he presumably agreed with the majority that the good-faith inquiry should be limited to the contents of the affidavit, he thought the majority should have held (just as in Carpenter) that the affidavit contained enough facts supporting probable cause to be saved by Leon. United States v. Laughton, 409 F.3d 744, 752-53 (6th Cir. 2005) (Gilman, J., dissenting).

142. In addition to Judge Gilman's Carpenter concurrence, the Laughton majority also appealed to the implications of the circuit's decision in United States v. Weaver, 99 F.3d 1372 (6th Cir. 1996), and cautioned that looking beyond the four comers of the affidavit would "lead to the very kind of subjectivity that the Supreme Court has repeatedly and explicitly rejected [in its Leon jurisprudence]." Laughton, 409 F.3d at 752.

143. In light of the history just recounted, it would not be surprising if the Sixth Circuit decided to rehear Laughton en banc.

144. 312 F.3d 862 (7th Cir. 2002).

145. Id. at 869 . 
question presented in Hove. ${ }^{146}$ The Hove view has also been followed by federal district courts in Tennesse $e^{147}$ and Vermont ${ }^{148}$ and by state courts in Colorado, ${ }^{149}$ Virginia, ${ }^{150}$ Ohio, ${ }^{151}$ and Alabama. ${ }^{152}$ For the most part, these opinions follow Hove with little independent analysis. ${ }^{153}$

Summing up, the courts that have addressed whether information not presented to the magistrate can be used to prove good faith have split, with perhaps a slight majority leaning toward the Ninth Circuit view. Most of these courts have seen little need to mount sustained arguments for their positions. ${ }^{154}$ Indeed, one gets the impression from reading the

\section{Id. at 872 .}

147. See United States v. Corrigan, 809 F. Supp. 567, 569-70 (M.D. Tenn. 1992) (rejecting the government's argument that an officer simply forgot to include in his affidavit any information about the date when he received information that was intended to establish probable cause for the issuance of a warrant).

148. See United States v. Turner, 713 F. Supp. 714, 724-25 (D. Vt. 1989) (stating that additional information known to an officer concerning reliability of informants was irrelevant to good faith under Leon where the officer declined to include the additional information in his affidavit because of fears that inclusion would jeopardize another investigation).

149. See People v. Miller, 75 P.3d 1108, 1116-17 (Colo. 2003) (refusing to allow information not presented to magistrate to cure staleness defect in the affidavit).

150. See Janis v. Commonwealth, 472 S.E.2d 649, 653-55 (Va. Ct. App. 1996) (following Hove on similar facts where affidavit supporting warrant failed to establish nexus between criminal activity and the place to be searched).

151. See State v. Klosterman, 683 N.E.2d 100, 104 (Ohio Ct. App. 1996) ("Information supporting probable cause that is known to the affiant, but not included in the affidavit or revealed to the issuing magistrate prior to issuance of the warrant, is not pertinent to the determination of whether an objectively reasonable officer should have known that the warrant was not based on probable cause.").

152. See Nelms v. State, 568 So. 2d 384, 388-89 (Ala. Crim. App. 1990) (quoting Hove and holding that affiant's subsequent oral testimony could not cure affidavit's failure to indicate when informant had observed narcotics at the defendant's residence).

153. The Klosterman opinion is an exception, as it provides a thoughtful discussion regarding the merits of the Hove approach. See Klosterman, 683 N.E.2d at 103-04.

154. Many of the most extensive discussions of the issue occur in cases that failed to resolve it. Judge Gilman's Carpenter concurrence is one example. See supra note 139 and accompanying text. Another is the Fourth Circuit's decision in United States v. Bynum, 293 F.3d 192 (4th Cir. 2002). (In the interest of full disclosure, I should note that I worked on this case while clerking for Judge Michael, who dissented.) In Bynum, the majority applied the good faith exception solely on the basis of materials presented to the magistrate and therefore declined to rule on the government's contention that the officer's good faith could be proven through consideration of information known to the officer but inadvertently omitted from the warrant application. Id. at 199. In dissent, Judge Michael argued that the government's position rested on the mistaken assumption that "objective good faith is determined by the reasonableness of the officer's belief in the existence of probable cause." Id. at 211 (Michael, J., dissenting). According to Judge Michael, Leon and Malley instead teach that the officer must have "an objectively reasonable belief that his affidavit gave the magistrate a substantial basis for finding probable cause.... Whether that belief is reasonable can depend only on the facts presented to the magistrate." Id. at 211-12. The majority saw considerable force in this line of argument, but observed that its acceptance would lead to an "anomaly" in the law of the good faith exception:

Even though Leon itself renders admissible evidence obtained pursuant to a warrant supported by an affidavit that lacks probable cause, Judge Michael's interpretation of 
cases just surveyed that many courts believe the answer to the question is obvious, even though they know that others have reached a different "obvious" answer. To my mind, the question is both close and complex. But before turning to my own analysis, I need to address a possible objection to my survey of the case law thus far. Some might feel that I have vastly understated the degree of support in the case law for seeking proof of the officer's good faith by looking "beyond the four corners of the affidavit." It might be thought that courts do this all the time in the context of what I will term "wrong address" cases.

\section{C. "Wrong Address" Cases}

In "wrong address" cases, many courts have relied on the executing officer's knowledge of the place to be searched to cure particularity defects in the warrant. A leading case in the genre is the Eighth Circuit's 1979 decision in United States $v$. Gitcho. ${ }^{155}$ There, agents obtained a warrant to search an apartment described as "4144 Geraldine, Apt. \# 7, Parc Chalet Apartments," 156 but the apartment the officers had surveilled, intended to search, and did search was actually 4146 Parc Chalet, Apartment No. $7 .{ }^{157}$ In upholding the validity of the warrant, the Eighth Circuit explained that " $[\mathrm{t}] \mathrm{he}$ test for determining the sufficiency of the description of the place to be searched is whether the place to be searched is described with sufficient particularity as to enable the

Leon would bar admission of evidence obtained pursuant to a warrant supported by the affidavit of an officer, who, in fact, possesses probable cause, but inadvertently omits some information from his affidavit.

Id. at 199 (majority opinion).

In People v. Deitchman, 695 P.2d 1146 (Colo. 1985), the Colorado Supreme Court unanimously affirmed the defendant's conviction but did not agree on a rationale. The four concurring opinions in the case all discussed whether suppression hearing testimony should be allowed to cure probable-cause deficiencies in the affidavit supporting a warrant request, though much of the discussion treated Colorado statutory and constitutional provisions instead of the federal Fourth Amendment. In a concurrence that partially anticipates the position taken in this Article, Justice Dubofsky argued that Colorado should adopt a limited good faith exception where evidence would be admitted despite an invalid warrant only in cases where "objective circumstances" prove that the officer had probable cause when he applied for the warrant and that he inadvertently omitted some of the information establishing probable cause from the warrant application. See id. at 1157 (Dubofsky, J., concurring). Eighteen years later, Colorado finally resolved the debate in Deitchman by adopting the Ninth Circuit view. See Miller, 75 P.3d at 1116-17.

155. 601 F.2d 369 (8th Cir. 1979).

156. Id. at 371 .

157. Id. Though the decision is not explicit on the point, it appears that the officers were not aware of the address discrepancy at the time they executed the search. The court explained that the officers' mistake was entirely understandable under the circumstances because, among other things, "Parc Chalet Drive" was "an unmarked street which [was] actually a parking lot." Id. 
executing officer to locate and identify the premises with reasonable effort, and whether there is any reasonable probability that another premise might be mistakenly searched." ${ }^{158}$ On these facts, the court said, the description satisfied the Fourth Amendment's particularity requirement primarily because "the agents executing the warrant personally knew which premises were intended to be searched, and those premises were under constant surveillance while the warrant was obtained." 159 Numerous federal and state courts have handed down similar decisions with similar reasoning. ${ }^{160}$

Because these wrong address cases appeal to the officer's knowledge to cure defects in the warrant, it is understandable that a few courts ${ }^{161}$ and commentators ${ }^{162}$ have treated them as authority for the proposition that an affiant's knowledge of information supporting probable cause but never communicated to the magistrate can establish the affiant's good faith. Yet the issues are quite different, as most courts seem (at some level) to recognize. ${ }^{163}$ As an initial matter, Gitcho and many of the other cases use the executing officer's knowledge of the place to be searched to uphold the validity of the warrant, not to apply the good faith exception. ${ }^{164}$ This is no accident because, in contrast to the typical Leon

158. Id. This formulation is a gloss on the Supreme Court's statement in Steele v. United States, 267 U.S. 498, 503 (1925), that the description of the place to be searched satisfies the particularity requirement if "the officer with a search warrant can with reasonable effort ascertain and identify the place intended."

159. Gitcho, 601 F.2d at 372. The court also noted that the address in the warrant was "reasonable for the location intended" because of the difficulty in determining the correct address, that the address stated in the warrant did not exist (thus making a search of the wrong residence unlikely), and that the officers actually searched the premises they intended to search. Id.

160. See, e.g., United States v. Hutchings, 127 F.3d 1255, 1259-60 (10th Cir. 1997); People v. Amador, 9 P.3d 993, 998-99 (Cal. 2000); State v. Alonzo, 675 So. 2d 266, 267-68 (La. 1996). Additional citations are collected in 2 LAFAVE, supra note 8, § 4.5(a), at 567 \& nn.18-19.

161. United States v. Martin, 297 F.3d 1308, 1319 (11th Cir. 2002); United States v. Word, No. IP 99-106-CR H/F, 2000 WL 724041 (S.D. Ind. May 31, 2000), aff'd I F. App'x 491 (7th Cir. 2001).

162. Coleman, supra note 119 , at 1725-31; Recent Case, supra note 119, at 1189-91.

163. Courts that have allowed the executing officer's knowledge of the place to be searched to cure mistakes in the warrant description have not treated those decisions as requiring them to allow an affiant's uncommunicated knowledge of probable cause to cure probable-cause deficiencies in the affidavit. Compare Gitcho, 601 F.2d at 372 (using executing officer's knowledge of premises to be searched to cure particularity defect in the warrant) with United States v. Martin, 833 F.2d 752, 75556 (8th Cir. 1987) (treating the question of whether affiant's knowledge of facts not communicated to the magistrate can cure probable-cause deficiency in affidavit as a matter of first impression without mention of its earlier decision in Gitcho); United States v. Gahagan, 865 F.2d 1490, 1496 (6th Cir. 1989) (following Gitcho) with United States v. Carpenter, 360 F.3d 591, 596-97 (6th Cir. 2004) (en banc) (declining to decide whether suppression hearing testimony can be used to cure probable-cause deficiencies in an affidavit without mention of Gahagan or related cases), cert. denied, 543 U.S. 851 (2004).

164. See, e.g., Gahagan, 865 F.2d at 1499 (holding that executing officer's knowledge of place 
case, the wrong address cases do not turn on whether the officer has reasonably relied on the magistrate's mistaken decision to issue the warrant. Instead, the problem in a wrong address case is that an officer's factual mistake (either reasonable or unreasonable) regarding the proper address of a place she intends to search gets incorporated into the warrant, which is then approved by the magistrate. The warrants at issue in these cases are not "facially deficient" in the sense of the fourth exception to the Leon good-faith rule, for a magistrate reading the warrant application would not be aware of any problem so long as the warrant description appears to single out a particular place. ${ }^{165}$ Because the particularity problem is not one that a magistrate could identify or correct, suppressing the evidence obtained under the warrant would in no sense be "[p]enalizing the officer for the magistrate's error." 166 Consequently, the reasons why courts admit evidence in the wrong address cases are different from those given in Leon. The real issue in these cases is whether the description in the warrant was particular enough to eliminate the risk of a mistaken search. Most courts have understandably concluded that this risk is negligible when the affiant is involved in the execution of the search and knows which premises were intended in the warrant application. The opposing argument is that evidence should be suppressed because the warrant's incorrect description creates a significant possibility-in some cases, a virtual certainty - of a mistaken search if the warrant is executed by an officer not involved in the investigation that preceded the warrant application. In other words, the decisive question in the wrong address cases is whether the Fourth Amendment requires that the description be particular enough to prevent a mistaken search by the officers who

to be searched cured warrant's particularity defect, rendering it unnecessary to invoke the good faith exception); Amador, 9 P.3d at 1000 (same); Smith v. State, 962 S.W.2d 178, 185 (Tex. Crim. App. 1998) (allowing consideration of evidence outside the warrant when determining if the description was sufficient). Gitcho itself was, of course, decided five years before Leon. This underscores the point that the wrong address cases turn on considerations that predate and are logically distinct from the considerations that drive the Leon good faith exception.

165. In other words, the magistrate can ensure that the description is not so facially vague that it risks a general search, but she cannot ensure that the address given for a specific place is accurate enough to prevent the possibility of a mistaken search. Whether the latter risk is present will generally become apparent only when officers try to execute the warrant. See Smith, 962 S.W.2d at 185 (explaining that the crucial moment in deciding whether a warrant particularly describes the place to be searched is the moment of the warrant's execution). In typical wrong address cases like Gitcho and the cases cited supra note 160, the officers had made a reasonable effort to identify the correct address and did not recognize the mistake in the address until after the warrant had been executed.

166. United States v. Leon, 468 U.S. 897, 921 (1984). 
actually execute the warrant or particular enough to prevent a mistaken search by any officer who might execute the warrant. ${ }^{167}$ Whatever the proper resolution of this question, it is quite distinct from that posed and answered by Martin, Hove, and their progeny. As a result, the wrong address cases have little bearing on whether Leon allows the use of suppression hearing testimony to prove an officer's good faith.

\section{ASKING THE RIGHT QUESTION: DID THE OFFICER HAVE AN OBJECTIVELY REASONABLE BELIEF THAT THE WARRANT WAS PROPERLY ISSUED?}

We have, then, a situation in which most of the courts and judges to address the issue have seemed to say categorically either (1) that courts may always look "beyond the four corners of the affidavit" to consider the "totality of the circumstances" bearing on the officer's good faith, or (2) that they are strictly limited to the materials considered by the magistrate because only these materials are sufficiently objective to count in the Leon inquiry. Further, many of the opinions argue for their categorical rules by simply citing Leon and other Supreme Court decisions. Such simple arguments are unconvincing, for they seek to find in Leon an answer to a question the Court did not ask. What Leon does provide is the proper way to approach the question. The proper approach, I shall argue, requires courts to focus on whether, taking all the circumstances known to the officer into account, the officer had an objectively reasonable belief that the warrant was properly issued. Once this question is framed properly, the difficulties with both the Eighth and Ninth circuit views become clear, and we reach the critical issue behind these cases: when (if ever) an officer can make an objectively reasonable mistake about what he has put in front of the magistrate.

\section{A. Textual Arguments Do Not Answer the Question, But They Do Show How to Ask It}

I begin with a quick review of the textual arguments offered by courts adopting the Eighth and Ninth circuit positions. The Eighth

167. Compare Smith, 962 S.W.2d at 181-85 (discussing conflicting lines of authority as to whether the warrant's description of the place to be searched must be sufficiently particular to eliminate the risk of a mistaken search by the actual executing officer or by any executing officer, and opting for the former view) with Amador, 9 P.3d at 1001 (Mosk, J., dissenting) (arguing that a search warrant's description is sufficiently accurate only if it would permit any officer to identify the premises to be searched with reasonable accuracy and that the executing officer's personal knowledge of the place to be searched is irrelevant). 
Circuit's Martin decision and the cases following it have most often justified their position by appealing to language in Leon and Anderson $v$. Creighton, ${ }^{168}$ but neither case shows that courts may look to information not shared with the magistrate in assessing good faith. Anderson does say that courts should "examin[e] ... the information possessed by the searching officials," but the Court was making the unsurprising point that everything an officer knew bears on the reasonableness of the officer's belief that a warrantless search was supported by probable cause. ${ }^{169}$ Nothing in Anderson suggests that a court should consider information known to the officer but never presented to the magistrate in deciding whether the officer had reasonable grounds for believing that a warrant was properly issued. ${ }^{170}$

The argument from Leon, though more plausible, is also unconvincing. Courts adopting the Martin view have relied on a Leon footnote stating that "all of the circumstances-including whether the warrant had previously been rejected by a different magistrate-may be considered" in deciding whether a reasonably well-trained officer would have known that the search was illegal despite the magistrate's authorization. ${ }^{171}$ It makes perfect sense, of course, to say evidence that an officer has engaged in magistrate shopping should be considered in evaluating the officer's good faith, even though that information will certainly not be included within the four corners of the affidavit. Yet the passage is assuming, as Leon does generally, ${ }^{172}$ the normal case where the officer has included all the relevant information supporting probable cause in her affidavit. This makes sense because the primary worry Leon sought to address was that officers might be unfairly penalized for mistaken legal judgments (i.e., that a certain set of facts amounts to probable cause) when they had acted properly by seeking guidance from a judge who could be trusted to have a greater command of the relevant law. ${ }^{173}$ There is no reason to read the passage as addressing whether information known to the officer but never communicated to the magistrate can establish the officer's good faith.

168. 483 U.S. 635 (1987).

169. See id. at 641 .

170. See United States v. Carpenter, 360 F.3d 591, 600 (6th Cir. 2004) (en banc) (Gilman, J., concurring) (explaining why Anderson is not relevant to the issue of whether information supporting probable cause but not shared with magistrate can be used to establish the officer's good faith), cert. denied, 543 U.S. 851 (2004).

171. Leon, 468 U.S. at 922 n.23.

172. See id. at $918-19$.

173. Id. 
The simple textual arguments in favor of the Ninth Circuit view are somewhat more powerful, but far from dispositive. I begin with the weaker, if more common, argument that allowing any appeal to information never shared with the magistrate would substitute a subjective good-faith standard for the objective good faith required by Leon. ${ }^{174}$ Leon did, of course, insist that the good-faith standard was objective rather than subjective. ${ }^{175}$ But the distinction between objective and subjective standards is subject to considerable ambiguity, both here and elsewhere. ${ }^{176}$ Courts accepting the argument that "objective" equals "presented to the magistrate rather than stored in the recesses of the officer's mind" are simply overreading Leon. ${ }^{177}$ In fact, the Court's adoption of an objective standard meant only that no affidavit could be saved simply by the officer's subjective belief (however ill founded) in

174. This argument was first made in Hove, and has been echoed in nearly every opinion adopting the Ninth Circuit view. See United States v. Hove, 848 F.2d 137, 140 (9th Cir. 1988) (stating that because the test of good faith under Leon is "clearly an objective one," a deficient affidavit "cannot be cured by an officer's later testimony on his subjective intentions or knowledge"); see also United States v. Koerth, 312 F.3d 862, 871 (7th Cir. 2002) (quoting Hove, 848 F.2d at 140), cert. denied, 538 U.S. 1020 (2003); United States v. Corrigan, 809 F. Supp. 567, 570 (M.D. Tenn. 1992) (stating that under Leon a police officer's reliance on a warrant must be "objective, not based on his own personal knowledge of the circumstances"); People v. Deitchman, 695 P.2d 1146, 1166 (Colo. 1985) (en banc) (Quinn, J., concurring) ("Utilization of the good faith exception to uphold the search and seizure in this case is to convert what I perceive to be nothing more than subjective good faith into an objective standard of reasonable reliance ....").

175. Leon, 468 U.S. at $922 \mathrm{n} .23$. Commentators have noted some lingering uncertainty about whether the Court really meant for the standard to be totally objective in the sense that an officer who subjectively believed that a search was unsupported by probable cause could nonetheless enjoy the protection of the good faith exception solely because he might reasonably have thought otherwise. Professor LaFave suggests the standard is purely objective in this way. See 1 LAFAvE, supra note $8, \S 1.3(\mathrm{e})$, at 71 . Others have claimed that courts usually treat subjective good faith as a necessary but not sufficient condition for application of the good faith exception. See Heller \& Reichmuth, supra note 37, at 19 (stating that with one exception, "lower federal and state courts have consistently treated subjective good faith as a threshold question when deciding whether to apply Leon's good faith exception, and have refused to apply the exception when the evidence in the case indicates that the officers acted in subjective bad faith"). Professors Wasserstrom and Mertens plausibly suggest that the issue of "subjective bad faith plus objective reasonableness" would rarely arise because "it is hard to see how a defendant could ever prove that the officer actually knew the affidavit did not establish probable cause" if the affidavit was substantial enough to support reasonable reliance. Wasserstrom \& Mertens, Exclusionary Rule on the Scaffold, supra note 8, at 119.

176. See Alschuler, supra note 19 , at 327 n.72 (stating that when the Leon Court declared that it was adopting an objective standard rather than a subjective one, it "said very little" because "[a]n 'objective' test becomes nearly indistinguishable from a 'subjective' test when a wide enough range of case-specific circumstances and personal characteristics are considered in judging reasonableness").

177. See United States v. Martin, 833 F.2d 752, 757 (8th Cir. 1987) (Lay, C.J., concurring) (stating that his "totality of the circumstances" approach is not a subjective test because it requires addressing "the objective reasonableness of the belief of an officer in [the affiant's] positionmeaning an officer with knowledge of the facts that [the affiant] possessed"). 
the existence of probable cause. Ruling out this kind of "pure heart, empty head" subjectivity was necessary, as the Court saw, to preserve incentives for police departments to train their officers in the requirements of the Fourth Amendment. ${ }^{178}$ The Court neither asked nor answered the question of whether information known to the officer but never shared with the magistrate could demonstrate the officer's objective good faith.

A more powerful argument is that Leon's and Malley's language suggests the Court's focus was on the adequacy of the probable-cause showing in the affidavit, not on what the officer knew at the time of the warrant application. To take but one example from Leon, the language of the third Leon exception states that an officer would not "manifest objective good faith in relying on a warrant based on an affidavit 'so lacking in indicia of probable cause as to render official belief in its existence unreasonable.",179 Similarly, the Court explained in Malley that courts should ask "whether a reasonably well-trained officer... would have known that his affidavit failed to establish probable cause and that he should not have applied for the warrant." 180 These passages certainly appear to support the Ninth Circuit view.

Similar support can be found in Leon's claim that the exclusionary rule should apply only when "a reasonably well trained officer would have known that the search was illegal despite the magistrate's authorization." $" 181$ A search conducted pursuant to a warrant is illegal under Gates, of course, if the magistrate did not have at least a "substantial basis for concluding that probable cause existed." follows that an officer can form beliefs about the legality or illegality of a warrant search only by looking at things from the magistrate's point of view. ${ }^{183}$ Because the reasonableness of the magistrate's probable-cause determination is solely a function of the information presented to the

178. Leon, 468 U.S. at 919 n.20. The exclusionary rule's role in encouraging police departments to train their officers to comply with the Fourth Amendment is often referred to as "systemic deterrence." See, e.g., Mertens \& Wasserstrom, Deregulating the Police, supra note 8, at 399.

179. Leon, 468 U.S. at 923 (emphasis added) (quoting Brown v. Illinois, 422 U.S. 590, 610-11 (1975) (Powell, J., concurring in part)).

180. Malley v. Briggs, 475 U.S. 335, 345 (emphasis added). The Court also observed that its rule would have the desirable consequence of encouraging each officer to "reflect, before submitting a request for a warrant, upon whether he has a reasonable basis for believing that his affidavit establishes probable cause." Id. at 343 (emphasis added).

181. Leon, 468 U.S. at 922 n.23.

182. Illinois v. Gates, 462 U.S. $213,238-39$ (1983) (internal quotation marks, ellipsis, and citation omitted).

183. See Leon, 468 U.S. at 922-23 ("[T]he officer's reliance on the magistrate's probable-cause determination... must be objectively reasonable, and it is clear that in some circumstances the officer will have no reasonable grounds for believing that the warrant was properly issued."). 
magistrate, ${ }^{184}$ it seems that information not presented to the magistrate could have no bearing on whether the officer could have reasonably believed that the search was legal. ${ }^{185}$

At minimum, these points make the textual arguments supporting the Eighth Circuit view look very weak. ${ }^{186}$ In the end, however, it would be misleading to say that the language of Leon and Malley settles the debate between the Eighth and Ninth circuit views. None of the language discussed above shows that the Supreme Court contemplated the possible use of suppression hearing testimony to cure probable-cause deficiencies in the affidavit. Instead, the Court's language simply reflects the natural assumption that the affidavit will contain the officer's entire basis for thinking that there is probable cause for the proposed search. While Leon and Malley do not settle the question of whether information not contained in the affidavit can establish good faith, they do show the proper way to ask the question.

\section{Two Ways of Posing the Question}

Implicit in the Eighth and Ninth circuit lines of authority are two different formulations of the question courts should ask in deciding whether an affiant's suppression hearing testimony justifies application of the good faith exception. The formulation favored by prosecutors and accepted (with varying degrees of explicitness) by courts holding the Eighth Circuit view asks whether the affiant officer had an objectively reasonable belief that he had probable cause for the search. The proper formulation, as some judges have recognized, asks whether the affiant officer had an objectively reasonable belief that the warrant was properly

184. See Whiteley v. Warden of Wyo. State Penitentiary, 401 U.S. 560, 565 n.8 (1971) (explaining that information known to the affiant but not disclosed to the issuing magistrate is irrelevant to the question of whether the warrant was issued on the basis of probable cause).

185. See United States v. Bynum, 293 F.3d 192, 211-12 (4th Cir. 2002) (Michael, J., dissenting).

186. One passage in Leon does support the Eighth Circuit view, though the decisions following Martin have not mentioned it. Leon dismissed as "speculative" the argument that evidence should always be excluded when the police fail to demonstrate probable cause because this would "deter[] future inadequate presentations [and] magistrate shopping." Leon, 468 U.S. at 918 . The Court also dismissed the argument that suppressing evidence because of particularity defects "might encourage officers to scrutinize more closely the form of the warrant and to point out suspected judicial errors." Id. Taken together, these statements might suggest that encouraging greater care in the warrant process is not one of the purposes of the exclusionary rule. Yet the statements are dicta that do not address the specific question treated in Martin and Hove, and in any event they have been partially undermined by the Court's 2004 decision in Groh v. Ramirez, 540 U.S. 551 (2004). There, the Court ruled that forfeiture of an officer's qualified immunity was an appropriate penalty for the officer's failure to detect a "glaring deficiency" in the form of a warrant. Id. at 564 (explaining that even a "cursory reading" should have revealed a particularity defect in the warrant). 
issued. ${ }^{187}$ The superiority of the second formulation is confirmed by both the structure of the four Leon exceptions and the implications of the Court's position that reliance on a "bare-bones" affidavit is always unreasonable.

\section{The Structure of the Four Leon Exceptions}

Leon and Malley teach that an officer is not entitled to rest blindly on the magistrate's approval of the affidavit. Instead, the officer must exercise some independent judgment about whether the magistrate has properly performed his role. As Judge Gilman helpfully put it, the crucial issue in Leon is "the reasonableness of the presenting officer's belief that the warrant was properly issued." 188

Though the Supreme Court said in Leon that magistrates will perform their proper function without regard to the sanction of exclusion, it has acknowledged - although perhaps not frankly enough ${ }^{189}$ - that the reality of the warrant process is not always perfect. ${ }^{190}$ Each of the four Leon exceptions allows exclusion of evidence to encourage officers to play some role in monitoring the integrity of the warrant process and to refrain from manipulating it to their advantage. ${ }^{191}$

The first two Leon exceptions speak directly to the integrity of the warrant process. Exclusion is still appropriate under Leon if "the magistrate ... was misled by information in an affidavit that the affiant knew was false or would have known was false except for his reckless disregard of the truth" or if the magistrate "wholly abandoned his judicial

187. See United States v. Carpenter, 360 F.3d 591, 598 (6th Cir. 2004) (en banc) (Gilman, J., concurring) ("Leon and Agnello make clear that the relevant question is whether the officer reasonably believed that the warrant was properly issued, not whether probable cause existed in fact."), cert. denied, 543 U.S. 851 (2004); Bynum, 293 F.3d at 212 (Michael, J., dissenting) ("Leon requires that the officer be able to entertain a reasonable belief that the magistrate had a substantial basis for finding probable cause."); State v. Klosterman, 683 N.E.2d 100, 104 (Ohio Ct. App. 1996) ("The officer's reliance on the warrant can be objectively reasonable only if his belief that the affidovit contains facts sufficient to create probable cause is itself objectively reasonable.").

188. Carpenter, 360 F.3d at 598 (Gilman, J., concurring).

189. For arguments that Leon rests in part on a naively optimistic view of the warrant process, see generally Goldstein, supra note 37; Nock, supra note 80.

190. See, e.g., Malley v. Briggs, 475 U.S. 335, 345-46 (1986) (noting that "it is possible that a magistrate, working under docket pressures, will fail to perform as a magistrate should").

191. Again, Malley is quite explicit on this point, suggesting that officers have a duty to minimize the dangers of magistrate failure "by exercising reasonable professional judgment." $I d$. at 346. See also Goldstein, supra note 37, at 1201 (stating that Leon contemplates a "credible prewarrant review" by a magistrate and a post-warrant review to "assure that the magistrate's review was indeed credible," and that the objectively reasonable officer "is expected always to know whether the magistrate has done what he should have done"). 
role in the manner condemned in Lo-Ji Sales, Inc. v. New York."192 The outcome of the warrant process only merits reliance if the input of the process was reliable. ${ }^{193}$ Thus, if the affiant knows (or at least strongly suspects) that some of the information provided to the magistrate was false, he cannot reasonably rely on the magistrate's probable-cause determination because the Fourth Amendment presupposes that the showing of probable cause made to the magistrate will be " "truthful' in the sense that the information put forth is believed or appropriately accepted by the affiant as true."194 Similarly, the officer cannot reasonably rely on a warrant if he knows that the magistrate has abandoned his judicial role, e.g., by becoming a member of the search party as in Lo-Ji Sales or by failing to read the warrant application. ${ }^{195}$ Again, the point is that even if an officer has an objectively reasonable belief that probable cause exists, he cannot reasonably rely on the warrant unless he can reasonably believe that the magistrate has properly performed his role as a neutral and detached arbiter of probable cause.

The third and fourth Leon exceptions recognize that even when the officer has been truthful with the magistrate and the magistrate has complied "in good faith" with the demands of his role, significant error is still possible. When a magistrate makes a glaring error by signing a warrant application obviously lacking in probable cause or wholly failing to describe with particularity the places to be searched or things to be seized, the officer has a responsibility to serve as a back-up system to ensure that Fourth Amendment rights are protected. Again, these exceptions require the officer to focus not on whether she has probable cause, but on whether the magistrate has properly performed his role. ${ }^{196}$

\section{3. "Bare-Bones" Affidavits}

A "bare-bones" affidavit is one that contains "wholly conclusory statements, which lack the facts and circumstances from which a

192. United States v. Leon, 468 U.S. 897, 923 (1984).

193. See id. at $922-23$ (emphasizing that the focus is on the warrant process by noting that suppression is still appropriate where the officer had "no reasonable grounds for believing that the warrant was properly issued") (emphasis added).

194. Franks v. Delaware, 438 U.S. 154, 165 (1978).

195. See United States v. Decker, 956 F.2d 773, 777 (8th Cir. 1992) (holding that the magistrate had abandoned his judicial role by signing the search warrant without reading the application).

196. In addition to providing some check on magistrate incompetence, the third and fourth exceptions also have the effect of limiting "magistrate shopping." While some commentators have justly criticized Leon for its potential to promote magistrate shopping, see, e.g., Wasserstrom and Mertens, The Exclusionary Rule on the Scaffold, supra note 8, at 109-10, the problem would undoubtedly be worse if the third and fourth Leon exceptions did not exist. 
magistrate can independently determine probable cause."197 It is well established that Leon does not suspend the exclusionary rule when an officer has relied on a bare-bones affidavit. ${ }^{198}$ For example, Leon would not save an affidavit saying only that "a reliable informant has told the affiant that he has recently obtained personal knowledge" that certain persons are selling heroin from a particular location. Leon would not apply in this example because an officer who presented such an affidavit could not reasonably believe that the magistrate had fulfilled her constitutional role by making an independent determination of probable cause rather than merely ratifying the bare conclusions of others. ${ }^{199}$ This explanation is, of course, consistent with my claim that the proper question under Leon is whether the officer had an objectively reasonable belief that the warrant was properly issued. In contrast, asking whether the officer reasonably believed that he had probable cause for the search leads to absurd results. If it were really true that there is good faith whenever the officer got a warrant and knew enough facts to support probable cause, then a bare-bones affidavit would not offend Leon as

197. United States v. Wilhelm, 80 F.3d 116, 121 (4th Cir. 1996) (quoting United States v. Laury, 985 F.2d 1293, 1311 n.23 (5th Cir. 1993)). Though the definition quoted in the text is representative, courts actually use the phrase "bare-bones affidavit" in subtly different ways. Usage varies both across and within jurisdictions, and seems to depend on the context and the result the court seeks to justify. Courts sometimes say that a bare-bones affidavit contains only conclusory statements. See, e.g., United States v. Perez, 393 F.3d 457, 465 (4th Cir. 2004) (stating that a barebones affidavit "'states only the affiant's belief that probable cause existed"' (quoting United States v. Williams, 224 F.3d 530, 533 (6th Cir. 2000))). On this usage, almost any affidavit more detailed than those in Nathanson v. United States and Aguilar v. Texas will qualify as more than bare-boned. See Nathanson, 290 U.S. 41, 44, 47 (1933) (rejecting as inadequate affiant's statement that "he ha[d] cause to suspect and [did] believe that" illegally imported liquor would be found on the premises to be searched); Aguilar, 378 U.S. 108, 109, 115-16 (1964) (rejecting as inadequate affiants' statement that they "ha[d] received reliable information from a credible person and believe[d]" that heroin would be found on the premises to be searched). At other times, courts say that an affidavit is barebones if a single critical element in its case for probable cause depends on a conclusory assertion, even if the affidavit contains far more information than a bare list of the affiant's conclusions. See, e.g., United States v. Helton, 314 F.3d 812, 816, 824-25 (6th Cir. 2003) (refusing to apply Leon to save a twenty-seven-page affidavit because the affidavit's case for probable cause depended critically on an uncorroborated anonymous tip). A dissenting judge in Helton argued that the court should have applied Leon because the affidavit was not bare-bones. Id. at 826 (Siler, J., dissenting). Finally, courts occasionally say that the phrase "bare-bones affidavit" describes any affidavit that falls within the third Leon exception, i.e., that is so lacking in indicia of probable cause that no reasonable officer could rely on it. See, e.g., United States v. Laughton, 409 F.3d 744, 748 (6th Cir. 2005) ("Affidavits that are 'so lacking in indicia of probable cause' have come be known as 'bare bones' affidavits.").

198. Leon, 468 U.S. at $923 \mathrm{n} .24$ (stating that an officer could not "obtain a warrant on the basis of a 'bare bones' affidavit and then rely on colleagues who are ignorant of the circumstances under which the warrant was obtained").

199. See United States v. Barrington, 806 F.2d 529, 532 (5th Cir. 1986) (stating that an officer could not reasonably rely on a bare-bones affidavit because "he had no good faith reason to believe the magistrate had made a probable cause determination"). 
long as the officer could flesh out his bare-bones affidavit with testimony at the suppression hearing about the basis for his conclusions. Such a result would be totally inconsistent with the cases on bare-bones affidavits. ${ }^{200}$ As Judge Michael put it in Bynum, " $[\mathrm{t}]$ he first problem with a bare-bones affidavit is not that the affiant's claims of probable cause might be unfounded, but that the conclusory character of those claims prevents the magistrate from performing her constitutional role."201 Accordingly, it must be wrong to approach the question of good faith by simply asking whether the officer had probable cause for the search. Instead, courts should ask whether a reasonable officer could have believed that the warrant was properly issued. ${ }^{202}$

\section{B. The Implications of Asking the Right Question}

Once the question has been properly formulated, it becomes easier to identify the shortcomings in the arguments courts have offered for the Eighth and Ninth circuit views.

As stated by Chief Judge Lay, the Eighth Circuit view is that (apparently in every case) "[d]eciding whether an officer acted in good faith requires an examination of the totality of the circumstances beyond the four corners of the affidavit." 203 By itself, the admonition to consider all the circumstances and to look beyond the four corners of the affidavit is not necessarily problematic. As I will explain, there are times when circumstances outside the affidavit do bear on whether the officer could reasonably have thought that the warrant was properly issued. The real question is not about whether courts should look "beyond the four corners of the affidavit," but about what they should be trying to see. Because good faith under Leon requires an objectively reasonable belief that the warrant was properly issued, the Eighth Circuit view clearly goes too far to the extent it implies that information establishing probable cause but not presented to the magistrate may always be used to establish the officer's good faith. To take the clearest counterexamples, an officer who deliberately omits certain information from his affidavit ${ }^{204}$ or

200. See, e.g., United States v. Glinton, 154 F.3d 1245, 1257 (1 l th Cir. 1998) (holding that Leon does not apply to bare-bones affidavits); United States v. Pigrum, 922 F.2d 249, 252-53 (5th Cir. 1991) (same); Crittenden v. State, 476 So. 2d 632, 635 (Ala. 1985) (same).

201. United States v. Bynum, 293 F.3d 192, 212 (4th Cir. 2002) (Michael, J., dissenting).

202. As noted above, Leon's language is entirely consistent with this point. Leon, 468 U.S. at 922-23 (stating that suppression is appropriate in those circumstances where "the officer will have no reasonable ground for believing that the warrant was properly issued").

203. United States v. Martin, 833 F.2d 752, 757 (8th Cir. 1987) (Lay, C.J., concurring).

204. Cases of "deliberate omission" are probably rare. One example is United States v. Turner, 
submits an unequivocally bare-bones affidavit of the sort condemned in Aguilar and Nathanson should not be allowed to establish his good faith by testifying at a suppression hearing that he had additional information supporting probable cause at the time of the warrant application. Such testimony would not show that the officer had a reasonable belief that the warrant was properly issued. Instead, it would at most show that the officer had a reasonable belief that he had probable cause for the search.

To say that the Eighth Circuit view, if applied literally, would lead to results clearly at variance with some Supreme Court cases may not say very much, for cases of deliberate omission or purely bare-bones affidavits are likely to be rare. If confronted with such a case, courts adopting the Eighth Circuit view might recognize some limitations on the use of suppression hearing testimony to prove good faith. Nevertheless, the Eighth Circuit approach causes serious problems. As actually applied by the courts, it leads to some mistaken applications of the good faith exception. More fundamentally, it undermines Fourth Amendment protections by encouraging officers to view the warrant process as a mere formality.

Courts adopting the Eighth Circuit view tend to accept (at least implicitly) the prosecution's claim that the good-faith inquiry turns on whether the officer had probable cause for the search, not on whether the officer reasonably believed the warrant was properly issued. For example, Chief Judge Lay ultimately justified his application of the good faith exception by remarking that the facts the officer knew but omitted from his affidavit "clearly were sufficient to justify a reasonable belief that probable cause existed." ${ }^{205}$ In the Eleventh Circuit's Martin opinion, the court explained that an officer had acted in good faith under Leon because " $[u]$ nder the totality of the circumstances, taking into account the facts known to [the officer] at the time he applied for the search warrant, we find that [the officer] reasonably believed that probable cause existed to execute a search warrant." ${ }^{206}$ By treating the officer's possession of probable cause as dispositive on the good-faith issue, courts send a clear message that evidence will be admitted under the good faith exception so long as officers have (1) a reasonable belief that

713 F.Supp. 714, 723-25 (D. Vt. 1989), where the court refused to apply Leon when the affiant intentionally witheld information supporting an informant's credibility and reliability out of concern that sharing this information with the magistrate would have jeopardized another investigation. For further discussion of Turner, see infra notes 260-64 and accompanying text.

205. Martin, 833 F.2d at 757 (Lay, C.J., concurring).

206. United States v. Martin, 297 F.3d 1308, 1320 (11 th Cir. 2002). 
there was probable cause for the search, and (2) a signed piece of paper with "Warrant" written across the top. That message contradicts Malley's emphasis on the need for officers to take some role in policing the integrity of the warrant process and thereby eliminates disincentives to magistrate shopping. Further, it tells officers that the task of putting together a proper warrant application has no real consequences, and thus dilutes one of the most important benefits of the warrant process: the discipline of having to articulate one's case for probable cause in writing to a neutral party. 207

Formulating the question properly also shows the weakness of another argument sometimes offered in support of the Eighth Circuit view. Many law enforcement agencies require their officers to use prescreening procedures as a part of the warrant application process, often requiring the signature of a prosecutor certifying that the warrant application meets constitutional standards. ${ }^{208}$ It is widely agreed that this sort of pre-screening is desirable, as it generally increases the quality of warrant applications and conserves judicial resources by eliminating the weakest applications before they reach the magistrate. ${ }^{209}$ Unsurprisingly, courts uniformly treat an officer's use of pre-screening procedures as indicative (though not dispositive) of the officer's good faith. ${ }^{210}$ Because

207. See Craig M. Bradley, The Good Faith Exception: Reasonable Exercises in Futility, 60 IND. L.J. 287, 292 (1985) (stating that the "most important" aspect of the warrant requirement is "that it forces the police to stop, think, write down their evidence, and submit it to someone else for approval"). The message that the warrant requirement is a mere formality is especially strong when courts move directly to the question of whether the officer had probable cause for the search without pausing to decide whether the affidavit established probable cause or whether the officer could reasonably have relied on the affidavit. See, e.g., United States v. Marion, 238 F.3d 965, 968-69 (8th Cir. 2001) (admitting evidence by moving directly to the question of whether the officer had probable cause for the search under the totality of the circumstances); United States v. Weeks, 160 F.3d 1210, 1212-13 (8th Cir. 1998) (same). If courts ask only whether the officer had probable cause for the search, the warrant appears to be nothing more than a piece of paper. In addition, courts' refusals to ask whether the officer could reasonably have relied on the affidavit make it unclear whether there was any need to rely on suppression hearing testimony in the first place.

208. 1 LAFAVE, supra note $8, \S 1.3(\mathrm{~d})$, at $67-68$.

209. See, e.g., Dripps, supra note 8, at 932-33.

210. See, e.g., Gomez v. Atkins, 296 F.3d 253, 264 (4th Cir. 2002) (stating that officer's use of "in-house" review procedures tended to show good faith); United States v. Frangenburg, 15 F.3d 100, 103 (8th Cir. 1994) (same). An officer's use of pre-screening procedures obviously tends to show subjective good faith, i.e., a well-intentioned effort to comply with appropriate procedures. As stated below in the text, pre-screening also tends to show objective good faith in the very limited sense that it becomes more reasonable to think the magistrate was right to sign a warrant when others agreed with him. Courts, however, sometimes display a tendency to give inordinate weight to the use of pre-screening procedures. See, e.g., United States v. Brown, 951 F.2d 999, 1005 (9th Cir. 1991) (stating that an officer's consultation with a government attorney before submitting a warrant is of "significant importance" in the good-faith inquiry). Courts should resist that tendency. Malley explicitly says that if an affidavit is woefully lacking in probable cause, the officer cannot establish his good faith by pointing to the greater incompetence of the magistrate who approved the warrant. 
critics claimed that Leon would discourage, or at least reduce incentives to use, pre-screening procedures, ${ }^{211}$ it seems especially appropriate that continued use of such procedures in Leon's wake should count as some evidence of good faith. All this is uncontroversial. Some courts, however, have suggested that if use of pre-screening can help to establish good faith, then evidence "beyond the four corners of the affidavit" is relevant and the Eighth Circuit's "totality of the circumstances" test must be correct. ${ }^{212}$ Evidence of pre-screening, of course, will sometimes be "within the four corners" in the form of a prosecutorial signature on the warrant application, but courts give credit for pre-screening whether or not this is true. In addition, evidence of previous rejections of the same warrant application by other magistrates counts against a finding of good faith, even though this information will rarely be included within the four corners of the affidavit. ${ }^{213}$ If the totality of the circumstances can be relevant to show bad-faith magistrate shopping, must it not also be relevant to show good faith?

This line of argument is correct in showing that facts not recited in the warrant application can be relevant to the good-faith inquiry. It does not show, however, that information supporting probable cause that was known to the officer but never shared with the magistrate may be used to prove the officer's good faith. Again, the relevant contrast is not between the four corners of the warrant application and the totality of the circumstances. Instead, the contrast is between information that could bear on the reasonableness of an officer's belief that a warrant was properly issued and information that could not. Information outside the four corners of the affidavit may fall on either side of this contrast. ${ }^{214}$

Malley v. Briggs, 475 U.S. $335,346 \mathrm{n} .9$ (1986). The same point should apply when pre-screening procedures fail to identify an affidavit too flimsy to support reasonable reliance.

211. 1 LAFAVE, supra note $8, \S 1.3$ (d), at 68 (stating that "under Leon, there is no reason to go through [pre-screeing] procedures and every reason not to"). In explanation of his point, Professor LaFave cites People v. Leftwich, 869 P.2d 1260, 1265 (Colo. 1994), where the court refused to apply Leon after noting, among other things, that prosecutorial pre-screening had raised doubts about whether the warrant application passed muster.

212. United States v. Martin, 297 F.3d 1308, 1319 (11th Cir. 2002).

213. United States v. Leon, 468 U.S. 897, 922 n.23 (1984).

214. The points in the text explain why it is wrong to frame the debate as one about acceptance or rejection of a "four-corners rule." Though "four-corners" language is probably harmless shorthand in most cases, courts are sometimes misled by it. For example, the Sixth Circuit recently held in United States $v$. Laughton that "a determination of good-faith reliance, like a determination of probable cause, must be bound by the four corners of the affidavit." 409 F.3d 744, 751 (6th Cir. 2005). Within a month of the Laughton decision, a district court in the Sixth Circuit relied on its four-corners language in refusing to consider unsworn testimony to the magistrate as part of the good-faith inquiry. United States v. Kemper, 375 F. Supp.2d 551, 554 \& n.1 (E.D. Ky. 2005) (stating that under Laughton the good faith exception did not permit consideration of the unsworn testimony 
Though the point will not bear too much weight, there is a rather obvious sense in which having one or more prosecutors sign off on a warrant application would increase the reasonableness of an officer's belief that the magistrate acted properly in issuing a warrant on the basis of that same application. ${ }^{215}$ Conversely, rejection of a warrant application at the pre-screening level would lessen the reasonableness of an officer's reliance if the same application were later approved by a magistrate. These facts, then, have a legitimate place in deciding whether an officer had an objectively reasonable belief that a warrant was properly issued. In contrast, information supporting probable cause that was not part of the warrant application (in either oral or written form) generally-a qualification follows - has no relevance to whether the officer could reasonably have believed that the warrant was properly issued. Such information may be part of the totality of the circumstances and certainly bears on whether the officer could reasonably have believed he had probable cause for a search, but that is the wrong question. It follows that the universal practice of considering pre-screening as evidence of good faith is wholly consistent with my criticisms of the Eighth Circuit view.

The Ninth Circuit view, at least in its most persuasive articulations, begins by correctly identifying the proper question as whether the officer had an objectively reasonable belief that the warrant was properly issued. Once the question is posed in this way, it may seem that the Ninth Circuit view must be correct. Whether a magistrate acted properly in

"[s]ince this information was not included in the affidavit"). The decision not to consider unswom testimony might or might not be correct. Compare State v. Tye, 636 N.W.2d 473, 479 (Wis. 2001) (refusing to apply Leon on the basis of a statement "that totally lacks an oath or affirmation") with United States v. Moore, 968 F.2d 216, 223 (2d Cir. 1992) (applying good faith exception because the "lack of an oath or affirmation by the presenting officer did not destroy the warrant's facial validity") and State v. Richardson, 943 F.2d 547, 550-51 (5th Cir. 1991) (applying Leon to save telephone warrant issued on the basis of unsworn testimony). My point here is simply that the Kemper court was wrong to think that the four-corners language in Laughton dictated its answer. A later Sixth Circuit decision handled Laughton's language more skillfully. In United States $v$. Frazier, the defendant argued on the basis of Laughton that information outside the four corners of the affidavit could never be relevant to the good-faith inquiry. 423 F.3d 526, 534 (6th Cir. 2005). The court properly distinguished Laughton because the relevant information (the fact that a confidential informant had taped two controlled buys of narcotics involving the defendant) had actually been presented to the issuing magistrate. Id. at 535-36. This aspect of Frazier is completely consistent with the position I take in this Article. At the magistrate's prompting, the officer in Frazier had added information about the taping of the controlled buys to five related affidavits but failed to add this information to the Frazier affidavit. Id. at 530 . Under these circumstances, the officer had a reasonable belief that the warrant was properly issued.

215. It is the same sense in which, other things being equal, one has more confidence in the correctness of a 9-0 Supreme Court decision than in the correctness of a 5-4 decision. 
issuing the warrant depends only on the facts known to the magistrate, and thus it would seem that information not presented to the magistrate could never have any bearing on the officer's good faith. ${ }^{216}$ The argument is a strong one, but it does not prove that information is irrelevant to the good-faith inquiry unless actually presented to the magistrate. Instead, it proves only that information is irrelevant to that inquiry unless the officer believes that the information was presented to the magistrate. Recall, for example, the facts of United States v. Hove. ${ }^{217}$ If the officer's suppression hearing testimony is believed, he dictated the facts supporting a nexus between criminal activity and the place to be searched to a stenographer who failed to include those facts in the affidavit. $^{218}$ As a result, the officer believed that the facts had been presented to the magistrate, and presumably also believed that the magistrate acted properly in issuing the warrant on the basis of those facts. In short, Hove shows how an officer might believe that a warrant was properly issued because he made a mistake about which facts he had presented to the magistrate. If this kind of mistake about the contents of the warrant application can be seen as objectively reasonable, the officer's belief that the warrant was properly issued would also be objectively reasonable. It would follow that facts not presented to the magistrate could sometimes be used to establish the officer's good faith.

Asking the right question, then, does not lead inexorably to the Ninth Circuit view. It leaves open the possibility that Leon can be read to forgive reasonable mistakes in the warrant application process and that suppression hearing testimony about information inadvertently omitted from the warrant application may sometimes be used to prove the officer's good faith. The correctness of this reading largely depends on whether the law of the good faith exception should recognize a category

216. See United States v. Carpenter, 360 F.3d 591, 598 (6th Cir. 2004) (en banc) (Gilman, J., concurring) (concluding that "information tending to show the existence of probable cause that was not disclosed to the issuing magistrate cannot logically have any bearing" on the good-faith inquiry because it cannot show "the reasonableness of the . . . officer's belief that the warrant was properly issued"), cert. denied, 543 U.S. 851 (2004); United States v. Bynum, 293 F.3d 192, 212 (4th Cir. 2002) (Michael, J., dissenting) (concluding that information not presented to the magistrate can never establish good faith because Leon requires "that the officer be able to entertain a reasonable belief that the magistrate had a substantial basis for finding probable cause" and "[w]hether that belief is reasonable can depend only upon the facts presented to the magistrate"); State v. Klosterman, 683 N.E.2d 100, 104 (Ohio Ct. App. 1996) (concluding that because an officer's reliance on a warrant can be objectively reasonable "only if his belief that the affidavit contains facts sufficient to create probable cause is itself objectively reasonable," information known to the affiant but not disclosed to the issuing magistrate is irrelevant to the good-faith inquiry).

217. 848 F.2d 137 (9th Cir. 1988).

218. Id. at 139 . 
of "objectively reasonable mistakes" in the warrant application process. That question cannot be answered by simple appeals to Leon's text.

Courts and judges embracing the Ninth Circuit view have paid little attention to the possibility of "objectively reasonable mistakes" in the warrant application process. Indeed, the entire notion can seem oxymoronic. $^{219}$ Yet the case law shows that in some situations courts applying the good faith exception do recognize the existence of reasonable mistakes. One example is a line of cases that I describe as "implicit reliance" cases. Another is the Supreme Court's 2004 decision in Groh v. Ramirez. ${ }^{220}$

The "implicit reliance" cases discuss affidavits with a common defect. The affidavits asserted that the place to be searched was the defendant's residence, but failed to tell the magistrate how the affiant knew that the defendant lived at that address. Because an affidavit must offer the magistrate more than bare conclusions, ${ }^{221}$ some courts ${ }^{222}$ have held that such affidavits fail to provide the magistrate with a "substantial basis for ... [concluding]' that probable cause existed."223 Other courts have said only that the failure to justify the affiant's conclusion that a

219. Probable cause doctrine, of course, recognizes the idea of a "reasonable mistake" in judgment. And in garden-variety cases applying the good faith exception, the officer has made a reasonable mistake in thinking that an insufficient affidavit established probable cause. Yet, as my colleague Vivian Hamilton pointed out to me, neither of these kinds of reasonable mistake is quite the same as a reasonable mistake in filling out a warrant application. To say that an officer had probable cause for a search that proved fruitless is to say that the officer made a reasonable judgment under conditions of factual uncertainty that turned out to be mistaken. To say that an officer made a reasonable mistake in thinking her warrant application established probable cause is to say that the officer made a reasonable judgment under conditions of legal uncertainty (i.e., uncertainty about whether a particular set of facts adds up to probable cause) that turned out to be mistaken. Because it is much harder to see anything "reasonable" about forgetting to include an important fact in a warrant application, the term "reasonable mistake" in this context falls uneasily on the ear. Perhaps the term "excusable mistake" would be more felicitous. Nevertheless, I have chosen the terms "objectively reasonable mistake" and "reasonable mistake" in order to emphasize continuity with Leon's emphasis on the reasonable officer as the benchmark of objective good faith. Cf. Groh v. Ramirez, 540 U.S. 551, 568 (2004) (Kennedy, J., dissenting) (describing a clerical error in a warrant form as a "reasonable mistake"). Readers disturbed by the terminology might find it helpful to think of reasonable mistakes in the warrant application process as mistakes that even reasonable officers well trained in Fourth Amendment law will make from time to time.

220. 540 U.S. 551. As I explain below, Justice Kennedy's and, to a lesser extent, Justice Thomas's dissenting opinions argue vigorously and explicitly for the recognition of reasonable mistakes in the warrant application process. Even the majority opinion, however, implicitly employs the notion of reasonable mistake.

221. Illinois v. Gates, 462 U.S. 213,239 (1983) ("Sufficient information must be presented to the magistrate to allow that official to determine probable cause; his action cannot be a mere ratification of the bare conclusions of others.").

222. United States v. Brown, 832 F.2d 991, 994 (7th Cir. 1987); Braxton v. State, 720 A.2d 27, 42 (Md. Ct. Spec. App. 1998).

223. Gates, 462 U.S. at $238-39$ (citing Jones v. United States, 362 U.S. 257, 271 (1960)) (internal punctuation and alterations omitted). 
certain address was the defendant's residence might render the warrant invalid. ${ }^{224}$ Regardless of differences on the probable-cause issue, however, the First, ${ }^{225}$ Sixth, ${ }^{226}$ and Seventh ${ }^{227}$ circuits as well as state courts in Colorado, ${ }^{228}$ Maryland, ${ }^{229}$ California, ${ }^{230}$ and Louisiana ${ }^{231}$ have all applied Leon when confronted with this scenario. Significantly, many of these decisions rely (with varying degrees of explicitness) on suppression hearing testimony showing that the affiant actually had a sound basis for concluding that the defendant lived at the place to be searched but forgot to include this information in the affidavit. ${ }^{232}$

The First Circuit's decision in United States v. Procopio ${ }^{233}$ is representative. There, officers initially obtained a warrant for the wrong apartment, but discovered their error at the scene and then telephoned an officer who prepared a new warrant application with the correct address. The affidavit, however, failed to explain how the police knew that the new address was the defendant's. ${ }^{234}$ The First Circuit had no difficulty

224. See, e.g., United States v. Procopio, 88 F.3d 21, 28 (1st Cir. 1996) (stating that Leon applied "whether or not this is a defect in the application"); People v. Gall, 30 P.3d 145, 151 (Co. 2001) (admitting evidence while stating that the affidavit "arguably failed to provide a substantial basis for the issuing magistrate's action"). At least one court has concluded that an affidavit failing to explain how an officer discovered the location of the defendant's residence satisfied the probablecause standard under a "clearly erroneous" standard of review. United States v. Baldwin, 987 F.2d 1432,1436 (9th Cir. 1993). This result seems doubtful, as it seems to contradict the long-standing principle that a magistrate should not simply ratify the affiant's bare conclusions. See Gates, 462 U.S. at 239.

225. United States v. Shea, 211 F.3d 658, 666 (1st Cir. 2000); Procopio, 88 F.3d at 28.

226. United States v. Van Shutters, 163 F.3d 331, 337-38 (6th Cir. 1998).

227. Brown, 832 F.2d at $994-96$.

228. Gall, 30 P.3d at 152 .

229. Braxton v. State, 720 A.2d 27, 48 (Md. Ct. Spec. App. 1998).

230. People v. Bell, 53 Cal. Rptr. 2d 156, 171 (Cal. Ct. App. 1996), partially abrogated on other grounds as recognized in People v. Athar, 129 Cal. Rptr. 2d 351, 360 (Cal. Ct. App. 2002).

231. State v. Varnado, 675 So. 2d 268, 270-71 (La. 1996).

232. See, e.g., Braxton, 720 A.2d at 48 (justifying application of the good faith exception in part by noting that the officer had obtained the defendant's address from an arrest record, a fact which apparently emerged during the suppression hearing); Bell, $53 \mathrm{Cal}$. Rptr. $2 \mathrm{~d}$ at 171 (excusing officer's omission of basis for conclusion that suspects lived at place to be searched after noting that the prosecution offered to put on proof that the officer had confirmed the suspects' residence through a check of utility records). In United States $v$. Van Shutters, the affidavit failed to indicate why the officer believed the defendant had any connection with the place to be searched. $163 \mathrm{~F} .3 \mathrm{~d} 331,336$ (6th Cir. 1998). Nevertheless, the court applied Leon on the questionable ground that the detailed description of the premises in the affidavit supported "a common sense inference ... that the affiant visited the premises himself and presumably either observed [the suspect] in the residence, or determined through investigation that [the suspect] frequented the premises." $I d$. at 337. The court may have found this inference to be plausible because of the officer's suppression hearing testimony that he had "personally verified" the link between the defendant and the place to be searched, even though the court stated that this information was not relevant. Id. at 337 n.4.

233. 88 F.3d 21 (1st Cir. 1996).

234. Id. at 28. 
applying the good faith exception. According to the court, the officers who had directed the preparation of the new warrant application had "ample basis" to conclude that the defendant lived at the new address because they knew from surveillance that he lived in the building and because moments before he had answered from that apartment when they called his name. ${ }^{235}$ The court explained,

The focus in a warrant application is usually on whether the suspect committed a crime and whether evidence of the crime is to be found at his home or business. That hardly makes the address unimportant: to invade the wrong location is a serious matter. But so long as the affidavit itself asserts a link between the suspect and the address, it is easy to understand how both the officer applying for the warrant and the magistrate might overlook a lack of detail on a point often established by the telephone book or the name on a mailbox.

To relate the court's point to my earlier claims, we could say that the officers in Procopio believed that the warrant was properly issued because under the circumstances they thought they had conveyed their entire case to the magistrate. From their point of view, the circumstances made it obvious how they knew where the defendant lived and they apparently thought this was clear to the magistrate as well. Was their mistake about the contents of the warrant application a reasonable one? The court clearly thought so. The quoted passage suggests that this sort of mistake might be made by even the most conscientious officer.

It is also significant that the court implicitly relied on suppression hearing testimony in concluding that the omission in the warrant application was the result of a reasonable mistake. The defect in the application appears minor, and the mistake reasonable, only in light of the court's knowledge of what the officers knew but failed to tell the magistrate. If the court had not been sure that the officers had reasonable grounds for their conclusion that the defendant lived at the new address, it might have treated the case differently. ${ }^{237}$ It appears, then, that the

235. Id.

236. Id. Other courts have made similar statements. See, e.g., People v. Gall, 30 P.3d 145, 152 (Colo. 2001) (explaining that an officer's failure to explain how he knew the suspect resided the targeted address was understandable because "the suspect was not unidentified, a fugitive from justice, or a transient without regular living quarters"); Bell, 53 Cal. Rptr. $2 \mathrm{~d}$ at 171 (observing that in most instances identifying a suspect's residence is a "routine matter" and that "the most obvious and routine things are the easiest to forget and their absence least noticeable").

237. See Procopio, 88 F.3d at 28 (stating that "to invade the wrong location is a serious matter"). The good-faith analysis would look quite different if, for example, the officers' only reason for thinking the suspect lived at the address to be searched was an uncorroborated anonymous tip. $C f$. Illinois v. Gates, 462 U.S. 213, 227 (1983) (stating that an uncorroborated anonymous tip would not 
Procopio court did look to information known to the officers but not shared with the magistrate in reaching the conclusion that the officers acted in good faith and that it did so precisely because the mistake in the warrant application was a reasonable one. ${ }^{238}$

Justice Kennedy's and Justice Thomas's dissenting opinions in Groh v. Ramirez, ${ }^{239}$ a qualified immunity case, ${ }^{240}$ offer further support for the propositions that courts sometimes recognize the existence of reasonable mistakes in the warrant application process and that such mistakes are relevant to the good-faith analysis. In Groh, the defendant, Officer Groh, received a tip from a citizen informant indicating that the Ramirez family might have a large cache of weapons on their Montana ranch. Groh completed a warrant application and an affidavit listing various types of weaponry as the things to be seized. ${ }^{241}$ Unfortunately, when Groh prepared the actual search warrant for the magistrate's signature, he

provide a magistrate with a substantial basis for finding probable cause). Indeed, in such circumstances it would be misleading for an officer to assert without explanation that the suspect lived at the address to be searched, for in the absence of explanation a court would likely assume that the officer had connected the suspect to the address through some more reliable means.

238. On my reading, Procopio regards the officers as making a reasonable factual mistake about the contents of the affidavit-they were reasonably unaware of the gap between what they knew and what they told the magistrate. Although the passage quoted in the text supports my interpretation, it might be possible to read Procopio as simply saying that the affidavit was not so lacking in indicia of probable cause that no reasonable officer would have submitted it to a magistrate. One might, in other words, think of the officers as making not an excusable factual mistake about the contents of the affidavit, but an excusable legal mistake about whether an affidavit must provide the magistrate with an independent basis for the officers' conclusions about where the defendant lived. $C f$. Groh v. Ramirez, 540 U.S. 551, 569 (2004) (Kennedy, J., dissenting) (arguing that the majority opinion wrongly treated an officer's clerical error as a mistake of law rather than a mistake of fact). If this alternative reading is correct, Procopio and related cases offer little support for my position. But is it correct? And how might one decide?

I suggest that if the courts regard an officer's error as legal, they will at some point expect officers to stop repeating the error. See United States v. Johns, 948 F.2d 599, 604-06 (9th Cir. 1991) (applying Leon to save the fruits of a "sneak and peek" warrant search but warning that future sneak and peek searches conducted without adequate notice to the search target would not receive the protection of the good faith exception). Just as the sphere of qualified immunity shrinks as the law becomes more "clearly established" in its details, reasonable officers can be expected to learn that they must include in the affidavit information explaining how they know where defendants live. I doubt, however, that courts would ever announce that they have forgiven a Procopio-style omission for the last time. See Oesby v. State, 788 A.2d 662, 667-68 (Md. Ct. Spec. App. 2002) (applying the good faith exception where the officer failed to explain how he knew where the defendant lived despite an earlier Maryland precedent clearly stating that an affidavit would not establish probable cause without this information). If I am right, the point suggests that courts are treating the sorts of omissions in Procopio as reasonable factual errors regarding the contents of the affidavit.

239. 540 U.S. at 566-71 (2004) (Kennedy, J., dissenting); id. at 571-80 (Thomas, J., dissenting).

240. Although Groh is a qualified immunity case, it has relevance for the good faith exception because under Malley the standards for application of the good faith exception and for qualified immunity are the same. Malley v. Briggs, 475 U.S. 335, 344 (1986).

241. Groh, 540 U.S. at 554. 
listed as the property to be seized "a single dwelling residence two story in height which is blue in color and has two additions attached to the east."242 Apparently, Groh made a clerical error by substituting his description of the place to be searched for his description of the property to be seized. The magistrate failed to catch the error and signed the warrant. $^{243}$ Groh then led a team of officers in executing the search, keeping the search at all times within the scope described in the affidavit and the warrant application. ${ }^{244}$

No incriminating items were found, but the Ramirez family filed a $\S$ 1983 suit against Groh and his fellow officers. ${ }^{245}$ The Ninth Circuit threw out all the claims except that against $G r o h,{ }^{246}$ and the Supreme Court affirmed. ${ }^{247}$ The Court first held that the warrant was invalid and the search unconstitutional because the actual warrant totally failed to particularly describe the things to be seized. ${ }^{248}$ The Court then held that Groh was not entitled to qualified immunity because the error in the warrant was so glaring that even a casual glance ought to have brought the error to the officer's attention. ${ }^{249}$ In dissent, Justice Kennedy argued that Groh ought to have been granted qualified immunity because "an officer's failure to recognize his clerical error on a warrant form can be a reasonable mistake." 250 Justice Kennedy further argued that the mistake was factual, not legal-the officer acted on the basis of a mistaken belief that the warrant contained a proper description of the things to be seized. $^{251}$ A separate dissent by Justice Thomas argued that "it is inevitable that officers acting reasonably and entirely in good faith will occasionally make ... errors" like Officer Groh's. ${ }^{252}$ Although only the dissenters explicitly invoked the idea of a reasonable mistake in preparing the warrant application, the majority opinion showed some receptiveness to their arguments by emphasizing that even "a simple

242. Id. at $554-55 \mathrm{n} .2$.

243. Id. at 555 .

244. Id.

245. Id.

246. Ramirez v. Butte-Silver Bow County, 298 F.3d 1022, 1028 (9th Cir. 2002) aff d sub nom. Groh v. Ramirez, 540 U.S. 551 (2004).

247. Groh, 540 U.S. at 566.

248. Id. at 557-58. Although Groh involves a particularity defect rather than a probable-cause deficiency, its treatment of mistakes in the warrant application process should apply quite generally.

249. Id. at 564-65 ("[E]ven a cursory reading of the warrant in this case-perhaps just a simple glance-would have revealed a glaring deficiency that any reasonable police officer would have known was constitutionally fatal.").

250. Id. at 568 (Kennedy, J., dissenting).

251. Id. at 567-69.

252. Id. at 579 (Thomas, J., dissenting). 
glance" at the warrant would have been enough to alert Officer Groh to his error. ${ }^{253}$ This aspect of the majority opinion could be read to imply that a more reasonable failure to detect a clerical error in the warrant application might merit different treatment under Leon. The majority may simply have thought that Officer Groh's error was unreasonable because of the glaring deficiency in the affidavit. ${ }^{254}$

Both the Procopio-style implicit reliance cases and Groh, then, suggest that there can be such a thing as a reasonable mistake in the warrant application process. Indeed, the implications of a contrary view seem inconsistent with the spirit of Leon. The challenge is to come up with an approach that draws reasoned lines in this area without collapsing into the views of either the Eighth or the Ninth circuits. To do that, we first need to get a sense of the spectrum of possible cases in which officers fill out deficient warrant applications and later try to bolster those applications with suppression hearing testimony.

\section{THE FormS OF THE SHADOW: REASONABLE AND UNREASONABLE MISTAKES IN THE WARRANT APPLICATION PROCESS}

Commendably, there is a high resolve in many policemen to ferret out the last shred of probable cause; regrettably, there is a concomitant inertia in those policemen toward putting it down on paper. That gap between the latent and the kinetic (with its Fourth Amendment consequences) echoes T.S. Eliot in The Hollow Men, "Between the idea and the reality, between the motion and the act, falls the Shadow." In the case at bar, the shadow fell between what the police worked up and what the police wrote down. ${ }^{25}$

Cases in which officers claim to have omitted information supporting probable cause from their warrant applications can take many forms. At the risk of being crude, I will group the cases into four categories. I will usually refer to these categories as Type I cases, Type II cases, etc. But they can also be labeled (somewhat tendentiously) as "knowing omission" cases, "major omission" cases, "minor omission" cases, and "pure transmission error" cases. ${ }^{256}$

253. Id. at 564 (majority opinion).

254. 1 LAFAVE, supra note $8, \S 1.3(\mathrm{f})$, at 86 . Professor LaFave endorses the dissenters' position that Officer Groh made a reasonable mistake in preparing the warrant and concludes that the majority opinion is "flat-out wrong" as an application of Leon. Id. at 85.

255. Hignut v. State, 303 A.2d 173, 175 (Md. Ct. Spec. App. 1973).

256. The usual disclaimers about typologies apply. Obviously, my categories are not selfapplying, their boundary lines may be fuzzy, and the application of a label is no substitute for analysis. Drawing lines between Type II and III cases, in particular, ultimately requires context- 


\section{A. Type I "Knowing Omission" Cases}

In a knowing omission case, the affiant officer omits information supporting probable cause from his affidavit either because of a conscious decision to withhold information from the magistrate or (more likely) a culpable failure to understand the legal requirements for establishing probable cause. In either case, the key point is that the officer has no remotely reasonable basis for believing that he has shared his entire case for probable cause with the magistrate.

It may seem that an officer would never knowingly fail to include in his affidavit information that would support probable cause, ${ }^{257}$ but there are actually many reasons why he might do so: simple laziness, a desire to save time, a (possibly mistaken) judgment that the affidavit already contained enough information to establish probable cause and that more information was unnecessary, a desire to protect the identity of informants, ${ }^{258}$ or a belief that the magistrate would rubber stamp anything put in front of her. What is truly rare is for an affiant to admit during the suppression hearing that the omission was self-conscious and intentional. In that context, the most officers are likely to admit is that they forgot to include the relevant information. ${ }^{259}$ So far as I am aware, the only reported case involving self-conscious, deliberate omission of information supporting probable cause is United States v. Turner. ${ }^{260}$ In that case, the affidavit's probable-cause showing depended crucially on a tip from an informant whose information was characterized only as "reliable and substantiated by independent investigation in the past."

sensitive judgments about what counts as a reasonable mistake in the warrant application process. All that being said, the categories are still useful in getting the lay of the land.

257. In contrast, officers have an obvious motive to omit from their warrant applications information that would undercut their efforts to show probable cause. Courts have properly refused to apply the good faith exception in such cases. See, e.g., United States v. Vigeant, 176 F.3d 565, 573-74 (1st Cir. 1999); United States v. Reilly, 76 F.3d 1271, 1280 (2d Cir. 1996).

258. See NCSC Study, supra note 80 , at 53 (reporting that in three study cities affidavits were self-consciously drafted to include the minimum information necessary to establish probable cause "to limit the avenues of attack by the defense and to protect the identity of informants").

259. A good example is State v. Parmar, in which officers obtained a warrant to search for a BB gun (among other things) but the affidavit provided no information explaining why the BB gun was relevant to the investigation. 437 N.W.2d 503, 509 (Neb. 1989), overruled by State v. Edmonson, 598 N.W.2d 450 (Neb. 1999). During the suppression hearing, the affiant stated that his failure to include information linking the BB gun to criminal activity was "an oversight." Id. See also People v. Miller, 75 P.3d 1108, 1116 n.9 (Colo. 2003) (prosecution argued that officer "simply overlooked stating an important detail when composing his affidavit"), cert. denied 541 U.S. 1082 (2004).

260. 713 F. Supp. 714 (D. Vt. 1989).

261. Id. at 715 . 
The affiant declined to provide any further information in the affidavit about the informant's reliability because he feared doing so would jeopardize another police investigation. ${ }^{262}$ In suppressing the evidence, the Turner court properly refused to consider any information about the informant's reliability that had not been presented to the magistrate. ${ }^{263}$ Though the court's reasoning was flawed, ${ }^{264}$ its decision to disregard this information was correct because such information could not support an objectively reasonable belief that the warrant was properly issued.

More common than deliberate omission cases like Turner are those in which the officer omits information from the affidavit because of a culpable failure to appreciate the legal requirements for establishing probable cause. A good example of such a case is State v. Klosterman. ${ }^{265}$ There, police obtained a warrant based almost entirely on information from what the affidavit characterized as "reliable and credible" confidential sources. ${ }^{26}$ Although the affiant testified at the suppression hearing about his reasons for trusting his informants, the court refused to apply the good faith exception because " $t$ t]he officer's reliance on the warrant can be objectively reasonable only if his belief that the affidavit contains facts sufficient to create probable cause is itself objectively reasonable." ${ }^{267}$ In Klosterman, there was no reasonable basis for such a

\section{Id. at 723 .}

263. Id. at $723 \mathrm{n} .8$. Elsewhere, the court noted its approval of the officer's decision to withhold information to protect another investigation, but said that the defendant should not be penalized by the existence of the other investigation and that the police could have and should have done more to demonstrate the informant's reliability through corroboration. $I d$. at 725 .

264. The court justified its decision by saying that Leon "does not focus on the officer's motive." Id. at $723 \mathrm{n} .8$. This appears to be an awkward way of saying that the consideration of information not presented to the magistrate would make the good-faith standard subjective rather than objective.

265. 683 N.E.2d 100 (Ohio Ct. App. 1996).

266. The relevant sections of the affidavit read as follows:

2. Affiant states that on March 10,1993, acting on information received [from] a reliable and credible confidential source, [he] began surveillance of [Klosterman's residence].

3. The reason for the surveillance is that a confidential informant within the last 72 hours, purchased illegal narcotics from [Klosterman at his residence].

4. This Affiant has received intelligence information from numerous confidential informants that [Klosterman] is involved in trafficking in large quantities of marihuana and psilocybin mushrooms. The Defendant has a previous conviction for Trafficking in Marijuana, Greene County Common Pleas Court in 1978.

5. As a result of the purchase of the illegal narcotics from the residence of [Klosterman] and reliable intelligence information gathered over a period of several years, there is probable cause to believe that [Klosterman] is involved in the distribution and sale of illegal narcotics.

Id. at 102. With the exception of the fifteen-year-old conviction, the affidavit's entire case for probable cause turned on whether the information from the confidential sources was trustworthy.

267. Id. at 104 . 
belief because the officer could not have entertained any illusion that the magistrate knew the facts supporting his judgment that the informants named in the affidavit were reliable. If the officer had simply claimed that he forgot to explain why he judged his informants "reliable and credible," it would have been a sufficient answer to say that forgetting of this sort cannot be objectively reasonable because it results from a failure to appreciate the relevant legal standards ${ }^{268}$ or from gross negligence in putting together the warrant application. Suppressing evidence in this kind of situation is necessary to provide incentives for police departments to continue training their officers to comply with Fourth Amendment requirements.

In Type I cases, then, the information omitted from the warrant application appears irrelevant to whether the officer had an objectively reasonable belief that the warrant was properly issued because the officer either was aware or clearly should have been aware of the gap between what he knew and what he told the magistrate. Other scenarios, however, are more difficult to evaluate.

\section{B. Type II "Major Omission" Cases}

In the major omission category of cases, the information omitted from the officer's affidavit is highly significant to the overall probablecause showing. While the presence of such holes in the affidavit need not show a complete failure to appreciate basic Fourth Amendment principles, it does suggest a significant lack of care in the warrant application process. The Eighth Circuit's decision in Martin and the Sixth Circuit's decision in Carpenter are representative Type II cases.

The Martin case involved an undercover investigation regarding some fur coats stolen from a Minnesota store. ${ }^{269}$ Walter Powers, a Hennepin County detective acting undercover, arranged three coat purchases from a man named Mastrian, who was an associate of the defendant Martin. ${ }^{270}$ During one of the coat buys, Powers observed

268. Courts have consistently held that a reasonably well-trained officer knows at least the basics of Fourth Amendment law. See, e.g., United States v. Leon, 468 U.S. 897, 919 n.20 (1984) (stating that Leon's objective standard "requires officers to have a reasonable knowledge of what the law prohibits"); Klosterman, 683 N.E.2d at 104 ("Courts objectively evaluating an officer's claim of good faith reliance must charge the officer with a certain minimum level of knowledge of the law's requirements."). It follows that any officer will be charged with knowledge that conclusory assertions of an informant's reliability and credibility do not establish probable cause in the absence of significant corroboration of the tip.

269. United States v. Martin, 833 F.2d 752, 753-54 (8th Cir. 1987).

270. Id. at 753 . 
Mastrian unloading coats from a large, tan duffel bag and assisted Mastrian in loading the coats back into the bag. ${ }^{271}$ On another occasion, other officers observing Mastrian's residence had seen Martin remove a large, tan duffel bag from the trunk of his car, carry it into Mastrian's house, and return it to the car a few minutes later. ${ }^{272}$ The officers then saw Mastrian and Martin leave Mastrian's residence together and drive in Martin's car to the previously arranged location of the coat buy. ${ }^{273}$ When Mastrian and Martin arrived together to complete a final transaction involving a trade of cocaine for fur coats, Powers arrested them both. ${ }^{274}$ After the arrest, Powers submitted a two-and-one-half page, typed affidavit in support of five different search warrants, including one warrant authorizing a search of Martin's car for evidence of participation in the stolen coat operation. ${ }^{275}$ The state court magistrate approved the warrant requests, which were promptly executed. ${ }^{276}$ The search of Martin's car uncovered none of the items sought, but did yield two firearms which ultimately led to Martin's arrest on federal firearms charges. ${ }^{277}$

Martin moved to suppress the evidence on the ground that the affidavit was so deficient that it neither established probable cause nor provided a reasonable basis for reliance under Leon. ${ }^{278}$ The district court agreed, and understandably so. ${ }^{279}$ The references to Martin in the affidavit stated only (1) that "Martin was seen loading a tan duffel bag into his car on January 6, 1986, at Mastrian's residence," (2) that Powers had seen the same bag while purchasing a coat on January 30 , (3) that Martin was seen on many occasions going to and from the same address where Powers bought the coat on January 30, and (4) that "Powers spoke with a man who identified himself as Terry" (Martin's first name) while calling a number Mastrian had provided to Powers. ${ }^{280}$ Although the majority opinion in Martin held that the officers reasonably relied on the affidavit in their search of Martin's car, ${ }^{281}$ the district court and Chief

271. Id. at 754 .

272. Id. at 753 . Powers obviously (and plausibly) assumed that he and the other officers were observing the same duffel bag.

273. Id.

274. Id. at 754 .

275. Id.

276. Id.

277. Id.

278. Id. at $754-55$.

279. Id. at 754 .

280. Id.

281. Id. at 756 . 
Judge Lay correctly concluded that the affidavit fell far short of establishing probable cause to believe that Martin's car would contain evidence regarding the stolen furs. Specifically, the affidavit omitted most of Officer Powell's reasons for concluding that Martin was a key player in the storage and sale of the stolen coats and that his car and the tan duffel bag were used with some regularity in transporting the coats. ${ }^{282}$

Although the Martin opinion does not recount Detective Powers's explanation for the omissions in his affidavit, it is easy to imagine what the detective would have said if questioned at the suppression hearing. No doubt he would have claimed that in the process of preparing an affidavit to support five separate warrants, he simply forgot to include all the details relating to Martin and his car. The prosecution could then have claimed that because of the detective's carelessness, he failed to notice the gap between what he knew and what he told the magistrate and therefore believed that the warrant was properly issued. Could that belief be considered objectively reasonable? Though the omission in Martin was significant, it differs from that in Klosterman because it did not rest on any failure to grasp the legal rudiments of probable cause. The problem seems rather to be that the officer did not think carefully enough about the need to establish probable cause for all the prongs of a multi-faceted search warrant request.

The Sixth Circuit's decision in Carpenter is another example of a Type II case. There, an officer conducting helicopter surveillance saw marijuana patches in fields roughly 900 feet from the defendants' house. ${ }^{283}$ The officer also saw beaten paths running between the marijuana patches and the back door of the house and observed two men (later determined to be the defendant Lonnie Carpenter and his son) walking from the patches toward the house. ${ }^{284}$ Unfortunately, much of this information was omitted by the ground officer who applied for the warrant. $^{285}$ The affidavit stated only that marijuana was seen growing "near the residence" and that there was "a road"286 connecting the

282. Chief Judge Lay ultimately concluded that Leon should apply because the information known to Detective Powers but omitted from the affidavit was "sufficient to justify a reasonable belief that probable cause existed." See id. at 757 \& n.3 (Lay, C.J., concurring).

283. United States v. Carpenter, 360 F.3d 591, 593 (6th Cir. 2004) (en banc), cert. denied, 543 U.S. 851 (2004).

284. Id.

285. Id.

286. Id. According to Judge Moore's dissent, this "road" was actually a "dirt path leading from the Carpenters' trailer to a separate tractor path that may have served as the connection between the city road and a homestead behind the Carpenters' trailer that had burned down several years before." Id. at 604 (Moore, J., dissenting). Apparently this "road" was not the same path as the "beaten paths" running between the marijuana patches and the residence. 
residence to the marijuana patches. ${ }^{287}$ The Sixth Circuit ultimately held that the affidavit's probable-cause showing was sufficiently robust to support reasonable reliance, ${ }^{288}$ a conclusion that seems forced for the reasons given in the dissenting opinion. ${ }^{289}$

As in Martin, the affiant here would no doubt have claimed that he inadvertently omitted some of the information relayed from the helicopter pilot because of carelessness and the haste with which he prepared the affidavit. Yet, even more strongly than in Martin, the affidavit here reveals a failure to think carefully about Fourth Amendment requirements in preparing the warrant application. Perhaps careful reflection on the requirement of a "nexus between the place to be searched and the evidence sought" ${ }^{290}$ would have led the officer to question whether proximity to marijuana patches and a connecting "road" were enough to establish probable cause for the search of a home. Surely scrutiny of such a simple affidavit ought to have revealed the absence of some of the information relayed by the helicopter pilot, and thus it seems doubtful that the affiant was reasonably unaware of the gap between what he knew and what he told the magistrate.

In Type II cases, then, the affiant's omission is inadvertent yet reflects both a lack of attention to probable-cause requirements in preparing the application and a failure to carefully review the application before submitting it to a magistrate. While the officer might have subjectively believed that he had given the magistrate everything he had, it is far from obvious that such a belief should count as objectively reasonable.

287. The affidavit was apparently drafted in a great hurry. As reprinted ("in exactly the syntax shown") in the opinion, the full text of the affidavit purportedly establishing probable cause for a search of the Carpenters' house read:

On June 23, 1999 at approx 12:30 pm, Helicopter Pilot Lt Bob Crumley was conducting an aerial search of Hawkins Co when he was flying over the above described property he saw numerous Marijuana Plants growing. Near the residence.

Upon information I received from Lt Crumley, there is a road connecting the above described residence to the Marijuana Plants. Having personal knowledge that Lt. Crumley is certified in the identification of Marijuana I feel there is probable cause to search the said residence and property and seize any illegal contraband found.

Id. at 593 (majority opinion).

288. Id. at 596 .

289. Id. at 601-04 (Moore, J., dissenting).

290. Id. at 594 (majority opinion) (quoting United States v. Van Shutters, 163 F.3d 331, 336-37 (6th Cir. 1998)). 


\section{Type III "Minor Omission" Cases}

Type III cases involve omissions that are not only inadvertent but also so minor that the omission seems entirely understandable and (perhaps) nonculpable. Procopio ${ }^{291}$ and the other implicit reliance cases are the paradigmatic examples here. In these cases, the affidavit asserts that the defendant lives at the residence to be searched but fails to explain the affiant's basis for the assertion. Although this failing may violate the rule that the warrant application cannot rest on bare conclusions, courts have regularly applied the good faith exception on the ground that "it is easy to understand how both the officer applying for the warrant and the magistrate might overlook a lack of detail on a point often established by the telephone book or the name on a mailbox. $" 292$

\section{Type IV "Pure Transmission Error" Cases}

In cases of "pure transmission error," the officer conducts an appropriate investigation and also properly evaluates the evidence in the light of Fourth Amendment requirements to assure herself that she can establish probable cause for the proposed search. The officer's only error is that she fails to properly record this process in the affidavit. A striking example is United States v. Corrigan. ${ }^{293}$ In Corrigan, the officer secretly taped a conversation with the defendant in which the defendant stated that he had a pipe bomb in the barn behind his house and offered to pay the officer to collect a gambling debt by roughing up another man. ${ }^{294}$ On the basis of this information, the officer applied for and obtained a warrant for the defendant's arrest. In the course of executing the arrest warrant, the officer asked the defendant's permission to search the premises, but the defendant refused. The officer then sought a search warrant from a different magistrate. ${ }^{295}$ Unfortunately, the officer's application for the search warrant neglected to mention the time when the incriminating conversation took place. As a result, the district court ruled that the search warrant was invalid because it did not provide any indication that the information establishing probable cause was not

291. United States v. Procopio, 88 F.3d 21 (1st Cir. 1996). For further discussion of this case, see supra notes 233-38 and accompanying text.

292. Procopio, 88 F.3d at 28.

293. 809 F. Supp. 567 (M.D. Tenn. 1992).

294. Id at 568 .

295. Id. at 569 n.5. 
stale. ${ }^{296}$ At the suppression hearing, the state argued that the evidence seized pursuant to the warrant should be admitted under Leon because the officer simply forgot to include the date of the conversation in his warrant application. ${ }^{297}$ Further, the state offered convincing proof that the information on which the warrant was based was not stale. ${ }^{298}$ Apparently, the officer had included the time of the incriminating conversation in his earlier application for the arrest warrant. Nonetheless, the Corrigan court granted the defendant's suppression motion on the ground that the officer's negligence had caused the warrant to be faulty: "Leon does not excuse a police officer's reliance on a warrant which he himself, however unintentionally, caused to be faulty."299 No doubt the officer could have been more careful in filling out the second warrant application, yet the error was purely clerical and was completely understandable under the circumstances. ${ }^{300}$ Further, admitting the evidence would not have facilitated perjury because there was clear and convincing proof that the officer's testimony at the suppression hearing was not perjured. ${ }^{301}$

\section{Id. at 568 .}

297. Id. at 569. The officer testified that he was under time pressure because it was late in the evening and the magistrate to whom the search warrant was submitted had a previous engagement. Further, the officer noted that unlike the arrest warrant form, the search warrant form contained no blank space for recording the date on which the officer received the information establishing probable cause. Id. at 569 n. 5 .

298. Corrigan never provided the date of the incriminating conversation, but the court indicated that the officer had provided the date to the magistrate who issued the arrest warrant and apparently regarded that date as establishing the relative freshness of the evidence.

299. Id. at 572.

300. The Ninth Circuit's decision in United States v. Hove, 848 F.2d 137 (9th Cir. 1988), is another case involving pure transmission error, see supra notes 128-33 and accompanying text (summarizing the facts and reasoning of Hove), but it is a less attractive candidate for application of the good faith exception than Corrigan because the Hove facts suggest a greater risk of perjury than was present in Corrigan. Unlike Corrigan, the only proof of the transmission error in Hove was the officer's post hoc testimony.

301. As will be discussed below, see infra notes $331-42$ and accompanying text, one of the reasons for barring the use of suppression hearing testimony to rehabilitate defective warrants is concern that such testimony will be perjured. In Corrigan, however, this concern seems misplaced for two reasons. First, the officer was "on the record" about the missing information before executing the search warrant because he had given the date of the incriminating conversation to the magistrate who issued the arrest warrant. Further, the warrant process could not provide any meaningful check on perjury regarding the staleness issue in any event. To the extent warrants serve as a check on perjury, they do so because the police must commit themselves to an account of their basis for the search before they actually see what evidence is there to be found. When police testify about their basis for finding probable cause after the search has taken place, they can more easily tailor their accounts of what was known beforehand to match the evidence actually discovered. In the case of staleness, however, the question is simply when the officers leamed what they say they knew before the search. Officers can lie about this, of course-for all we know, the officer in Corrigan could have been lying about the time of the taped conversation about the pipe bomb. The 


\section{E. Drawing Lines: Preliminary Considerations}

The preceding typology suggests a spectrum of cases where allowing omitted information to cure the affidavit's deficiencies ranges from less to more appealing. The first distinction to draw among these cases separates the knowing or grossly negligent omissions in Type I cases from the various inadvertent omissions ${ }^{302}$ in Type II, Type III, and Type IV cases.

It should be clear from the preceding discussions that Leon should not apply in Type I cases. Information knowingly omitted from a warrant application cannot affect the reasonableness of the officer's belief that the warrant was properly issued. Similarly, a bare-bones affidavit like that in Klosterman cannot be rehabilitated under Leon even if the officer claims after the fact that he "just forgot" to explain the basis for his conclusions. Whether characterized as fundamental legal errors about the requirements of probable cause or as grossly negligent mistakes in the warrant application process, the errors in Type I cases cannot qualify as objectively reasonable. This conclusion is of limited importance, however, because Type I cases are fairly rare. Indeed, even courts purporting to follow the Eighth Circuit view might well refuse to apply Leon if confronted with a true Type I case.

How, then, should we draw the line dividing those inadvertent omissions that can be cured with suppression hearing testimony from those that cannot? Plausible arguments can be made for drawing this line at each point along the spectrum running from Type II to Type IV cases. $^{303}$ All of the possible line-drawing approaches are compatible with the point I have insisted upon: that the proper question is whether the officer had an objectively reasonable belief that the warrant was properly issued. They differ in their positions on when (if ever) an officer can make an objectively reasonable mistake about what information she has put in front of the magistrate.

point, however, is that this kind of perjury is just as easy ex ante as it is ex post. Accordingly, the warrant process can do little to check perjury in this kind of case.

302. The phrase "inadvertent omissions" is something of a term of art. An officer might claim inadvertence even in cases involving bare-bones affidavits. Yet if such a claim is accepted, the officer's failure to recognize the deficiencies in the affidavit would be grossly negligent. "Inadvertent omission" cases in my usage encompass mistakes in the warrant application process that are, at worst, ordinary instances of negligence.

303. In other words, one can plausibly argue that suppression hearing testimony may be used to establish the officer's good faith in (1) Type II, III, and IV cases, (2) Type III and IV cases, (3) Type IV cases only, or (4) never. 


\section{ANSWERING THE QUESTION: A MidDle PATH ALLOWING LiMITED USE OF SUPPRESSION HEARING TESTIMONY TO PROVE GOOD FAITH}

\section{A. Moving Beyond the Magistrate-Versus-Officer "Blame Game"}

Once the issue is framed as one of whether there can be objectively reasonable mistakes in the warrant application process, the next step is to decide how Leon would have us answer the question. One approach that immediately suggests itself is to ask whether inadvertent omissions from the warrant application are better seen as "magistrate error" or "officer error." This approach is often used by courts, ${ }^{304}$ and has doubtlessly been encouraged by Leon's statement that suppressing evidence obtained in good-faith reliance on a warrant would be "[p]enalizing the officer for the magistrate's error, rather than his own." ${ }^{305}$ Yet the tendency of courts to resolve cases by classifying mistakes in warrant searches as either "magistrate error" or "police error" seems misguided. First, the question of whether the failure to identify shortcomings in an affidavit is the fault of the magistrate or the officer has proven manipulable. ${ }^{306}$ Second, the reality is that the magistrate is at fault in every case where a warrant is issued without probable cause, and often egregiously at fault when a warrant is issued in the absence of even a substantial basis for finding probable cause. Similarly, the officer is at fault in nearly every case. ${ }^{307}$

If both magistrate and officer have erred in Leon cases, perhaps courts are really asking whether the magistrate or the officer is more to blame for the warrant's deficiency. Although more promising, this approach is also inadequate. Consider the ordinary case for application

304. See, e.g., United States v. Martin, 297 F.3d 1308, 1320 (11th Cir. 2002) (explaining that the staleness problem in the affidavit was "primarily" a result of mistakes made by the issuing judge and that Leon should apply because "the officer need not pay for the judge's mistake"); United States v. Corrigan, 809 F. Supp. 567, 572 (M.D. Tenn. 1992) (refusing to apply Leon to cure a staleness problem in the affidavit because the problem was not "due to any error on the part of the magistrate, but rather due to the negligence of the police officer applying for the warrant").

305. United States v. Leon, 468 U.S. 897, 921 (1984).

306. Compare the Martin and Corrigan cases supra note 304. Both involved affidavits that failed to include any statements as to the freshness of the evidence supporting probable cause. Martin, 297 F.3d at 1314-15; Corrigan, 809 F. Supp. at 568. In both cases, the magistrates issued the warrants without noticing this deficiency. Martin, 297 F.3d at 1316; Corrigan, 809 F. Supp. at 571. The Corrigan court suppressed the evidence on the ground that the omission of the information regarding staleness was the officer's fault, not the magistrate's fault. Corrigan, 809 F. Supp. at 572. The Martin court admitted the evidence on the ground that the omission was the magistrate's fault. Martin, 297 F.3d at 1320.

307. Perhaps Massachusetts v. Sheppard, 468 U.S. 981 (1984), is an exception, as the Court observed that the officers in that case "took every step that could reasonably be expected of them." Id. at 989 . 
of the third Leon exception, in which the officer's affidavit contains his entire case for probable cause yet is still so insubstantial that a reasonable officer would never have submitted the warrant application for approval in the first place. In such a case, both the magistrate and the officer have made serious errors in deciding whether the facts in the affidavit established probable cause. Because we expect the magistrate to have greater expertise about the law of probable cause, her error seems greater than the officer's. ${ }^{308}$ Nonetheless, the Supreme Court said in Malley that excluding evidence in these circumstances was appropriate and did not amount to punishing the officer for the magistrate's error: when the officer's warrant request "is outside the range of the professional competence expected of an officer," he cannot "excuse his own default by pointing to the greater incompetence of the magistrate." 309 This passage suggests that Leon may require suppression even where the magistrate's error is more culpable than the officer's.

For these reasons, the appropriate question is not about the proper allocation of blame between magistrate and officer. Instead, it is whether (given the obvious fault of the magistrate) the officer's error is one that merits deterrence through application of the exclusionary rule. The answer to this question, as I shall explain below, depends both on the likelihood of changing police behavior through the threat of exclusion and on the effects such changes would have on the substantive values protected by the warrant requirement and by the Fourth Amendment itself. $^{310}$

\section{B. Warrants Can Protect Privacy Even When Magistrates Do Not}

At the broadest level, the modern law of the Fourth Amendment is about striking the proper balance between the privacy rights of citizens and the legitimate needs of law enforcement. ${ }^{311}$ The warrant requirement

308. See Malley v. Briggs, 475 U.S. 335, $346 \mathrm{n} .9$ (1986) ("It is a sound presumption that the magistrate is more qualified than the police officer to make a probable cause determination.") (internal quotation marks omitted); Leon, 468 U.S. at 921 ("In the ordinary case, an officer cannot be expected to question the magistrate's probable cause determination. ...").

309. Malley, 475 U.S. at 346 n.9.

310. On my reading, then, Leon's reference to the inappropriateness of "[p]enalizing the officer for the magistrate's error," 468 U.S. at 921 , is not meant to make application of the good faith exception turn on the outcome of a magistrate-versus-officer "blame game." Instead, the passage simply makes the general point that exclusion serves no purpose where it would be unlikely to shape police conduct in appropriate ways.

311. See, e.g., Christopher Slobogin, The World Without a Fourth Amendment, 39 UCLA L. REV. 1, 5-7 (1991) (explaining that American courts regulate search and seizure by balancing the state's interests in "effective law enforcement" and in "maintain[ing] the allegiance of its citizenry" 
is important chiefly for its procedural value in insuring that this substantive balance is struck correctly. ${ }^{312}$ Warrants protect privacy in a variety of ways, both by preventing unjustified searches altogether and by constraining officers' discretion in the execution of justified searches. $^{313}$ Some of the protections are provided by the interposed judgment of the magistrate, some by the warrant application process, and some by the warrant itself.

The most obvious function of the warrant requirement is to prevent "bad searches," i.e., searches not based upon probable cause. The classic exposition of this function was given by Justice Jackson in the 1948 case of Johnson v. United States. ${ }^{314}$ In that case, the government sought to justify a warrantless search of a hotel room by arguing, among other things, that the police officers clearly possessed sufficient grounds to justify issuance of a warrant at the time they searched the apartment. ${ }^{315}$ In rejecting this contention, Justice Jackson wrote,

The point of the Fourth Amendment, which often is not grasped by zealous officers, is not that it denies law enforcement the support of the usual inferences which reasonable men draw from evidence. Its protection consists in requiring that those inferences be drawn by a neutral and detached magistrate instead of being judged by the officer engaged in the often competitive enterprise of ferreting out crime. Any assumption that evidence sufficient to support a magistrate's disinterested determination to issue a search warrant will justify the officers in making a search without a warrant would reduce the Amendment to a nullity and leave the people's homes secure only in

against the interests of its citizens in "avoiding unnecessary searches and seizures"); Silas J. Wasserstrom \& Louis Michael Seidman, The Fourth Amendment as Constitutional Theory, 77 GEO. L.J. 19, 30 (1988). A growing literature suggests that the aims of the "original" Fourth Amendment were much narrower, see generally Thomas Y. Davies, Recovering the Original Fourth Amendment, 98 MiCH. L. REV. 547 (1999), but these historical arguments are well outside the scope of this Article.

312. For an argument that the Supreme Court's warrant jurisprudence has emphasized procedure over substance, see Wasserstrom \& Seidman, supra note 311, at 30-35.

313. See Coolidge v. New Hampshire, 403 U.S. 443, 467 (1971) (describing the "two distinct constitutional protections served by the warrant requirement" as "eliminat[ing] altogether searches not based on probable cause" and insuring that even necessary searches "should be as limited as possible"). In discussing the functions served by the warrant requirement, I will concentrate on the ways in which the requirement serves to safeguard the privacy of citizens (including criminal suspects). The process also benefits the government in certain ways. Most obviously, it provides an opportunity for police to correct shortcomings in their criminal investigations before it is too late. Professor Amar has argued that at the time of the Founding, warrants also aided peace officers by immunizing their actions from civil liability. See Akhil Reed Amar, The Bill of Rights as a Constitution, 100 YALE L.J. 1131, 1178 (1991).

314. 333 U.S. 10, 13-14 (1948).

315. Id. at $12-13$. 
the discretion of police officers.... When the right of privacy must reasonably yield to the right of search is, as a rule, to be decided by a agent. $^{316}$ officer, not by a policeman or government enforcement

The key ideas here are straightforward. First, privacy is sufficiently important that government intrusions should be prevented if possible rather than simply remedied after the fact. ${ }^{317}$ Second, "neutral and detached" magistrates are likely to be more hesitant to authorize intrusions than are police officers; i.e., they are more likely than police officers to strike the proper balance between the citizen's right to privacy and the imperatives of law enforcement. ${ }^{318}$ A third central feature of the Court's Warrant Clause jurisprudence follows from these points: the inferences supporting probable cause must be drawn by the magistrate rather than the officer. If the magistrate simply ratifies the judgments of the police officer, the protections provided by the warrant process are illusory. It is important to note that according to this classical justification for the warrant requirement, the critical element of the requirement's protection is the magistrate's independent, ex ante

316. Id. at 13-14 (footnotes omitted).

317. As Professor Stuntz has pointed out, this part of the classical justification for the warrant requirement is not entirely convincing. William J. Stuntz, Warrants and Fourth Amendment Remedies, 77 VA. L. REV. 881, 893 (1991). Ex post sanctions like the exclusion of evidence also deter ex ante, and so they too can serve to prevent as well as to remedy privacy violations. Id. Professor Slobogin, however, has argued that some type of ex ante review like the warrant procedure is necessary to effectively prevent privacy violations because (1) ex post sanctions cannot deter good-faith infractions and (2) ex post remedies like exclusion seem, as an empirical matter, to have relatively little effect on police conduct. See Slobogin, supra note 311, at 9-12.

318. In addition to their character as "neutral and detached," magistrates might also be thought more protective of privacy interests because their probable-cause judgments, unlike those of trial courts conducting suppression motions, are free from the subtle effects of hindsight bias. This point has received considerable attention from Professor Stuntz, who argues that the Supreme Court's warrant jurisprudence makes a great deal of sense if one assumes that the most important function served by the warrant requirement is to redress the problem of hindsight bias present in suppression hearings. Stuntz, supra note 317 , at 942 . As Stuntz aptly puts it, "[i]t must be much harder for a judge to decide that an officer had something less than probable cause to believe cocaine was in the trunk of a defendant's car when the cocaine was in fact there." Id at 912. See also United States v. Hawkins, 811 F.2d 210, 221 (3d Cir. 1987) (Rosenn, J., concurring and dissenting) ("The advantage of hindsight distorts the reasonableness inquiry in fourth amendment cases. Once we know that a search did turn up evidence of crime, we are more likely to view as well-founded suspicions which at the time would have appeared groundless, and arbitrary action of police as intuitive and discerning."). The Supreme Court occasionally has expressed a similar thought. See United States v. Martinez-Fuerte, 428 U.S. 543, 565 (1976) (stating that warrants serve "to prevent hindsight from coloring the evaluation of the reasonableness of a search or seizure"); Beck v. Ohio, 379 U.S. 89, 96 (1964) (stating that a warrantless arrest "bypasses the safeguards provided by an objective predetermination of probable cause, and substitutes instead the far less reliable procedure of an afterthe-event justification for the arrest or search, too likely to be subtly influenced by the familiar shortcomings of hindsight judgment"). 
judgment that probable cause exists-not the warrant application procedure or the actual piece of paper called the warrant. ${ }^{319}$

Though the centerpiece of the warrant requirement's privacy protections is the interposed judgment of the neutral and detached magistrate, the warrant application process also generates protections of its own. These protections may be effective in protecting citizen privacy even when the magistrate fails to do his job. First, the warrant application process tends to prevent bad searches by raising the costs of conducting a search. Police officers are less likely to go to the trouble of obtaining a warrant if they are not fairly confident that a search will be fruitful, and the discipline of making the case for a search to another person in writing may lead police to recognize gaps in their evidence that need filling in. ${ }^{30}$ Second, the warrant application process generates a valuable record for judicial review and ensures that there is no confusion between what was known to police before and after the search. ${ }^{321}$ Numerous commentators have recast this last benefit of the warrant requirement in more cynical terms: warrants make it harder for police to circumvent the requirements of the Fourth Amendment by committing perjury. ${ }^{322}$

The warrant requirement also serves to constrain police discretion in the execution of searches. First, the textual requirement that warrants particularly describe the place to be searched and the items to be seized serves to prevent general searches and to control the discretion of executing officers by controlling the scope of authorized intrusions. ${ }^{323}$

319. In making ex ante probable-cause determinations, the magistrate is, of course, constrained by the requirements for both probable cause and particularity: the magistrate must assure herself that there is probable cause to search this particular place for these particular items. See United States v. Stefonek, 179 F.3d 1030, 1033 (7th Cir. 1999) ("[T] he requirement of particularity backs up the requirement that warrants not issue except on probable cause by preventing the searching for and seizure of items that there is no probable cause to believe are either contraband or evidence of a crime.").

320. See infra notes $343-59$ and accompanying text.

321. See United States v. Christine, 687 F.2d 749, 757 (3d Cir. 1982) ("[T]he applicant for the warrant is committing to a public record the information that is known before the search so that, after the search takes place, there is no confusion between the ex-post and ex-ante positions of the applicant." (quoting S. SAlTzBURG, American CRIMINAL PRoCEDURE: CASES AND COMMENTARY $57(1980))$ ).

322. See infra notes $331-42$ and accompanying text.

323. Marron v. United States, 275 U.S. 192, 196 (1927). The particularity requirement actually serves as a check on general searches both by structuring the magistrate's probable-cause determination and by constraining official discretion in the execution of the warrant. As Judge Posner has explained, the particularity requirement backs up the probable-cause requirement in two steps:

The police ... officer who is seeking the warrant must submit to the judicial officer a precise description of what is sought to be seized, so that the judicial officer can 
Second, warrants "assure[] the individual whose property is searched or seized of the lawful authority of the executing officer, his need to search, and the limits of his power to search." ${ }^{324}$ These functions are primarily served by the warrant itself (i.e., the actual piece of paper); thus, some facial problems with a warrant may render it invalid even when the magistrate has made a proper probable-cause determination and the search has stayed within the bounds set by the magistrate. ${ }^{325}$

Allowing suppression hearing testimony to cure probable-cause deficiencies in the affidavit does not implicate those functions of the warrant requirement that deal exclusively with the execution of warrants - namely, the control of official discretion in the execution of the search and the "assurance function." It affects only those functions aimed at reducing the likelihood of a search without probable cause. As we have seen, there are several different ways in which the warrant process serves to prevent bad searches.

The most important check against bad searches is the interposed judgment of the neutral and detached magistrate. If I were writing on a

determine whether a valid law enforcement purpose would be served by the seizure of all items fitting the description. The description is then written into ... the warrant in order to make sure that the law enforcement officer who executes the warrant stays within the bounds set by the issuer.

Stefonek, 179 F.3d at 1033.

324. United States v. Chadwick, 433 U.S. 1, 9 (1977) (citing Camara v. Municipal Court, 387 U.S. 523, 532 (1967)). Courts have not been entirely clear about the nature and extent of this "assurance function," as was evidenced by the Supreme Court's decision in Groh v. Ramirez, 540 U.S. 551 (2004). The warrant in Groh was invalid because it completely failed to particularize the things to be seized because of a clerical error by the affiant. The officer argued that the purposes of the particularity requirement had been satisfied because a magistrate had found probable cause to search for all the items listed in the affidavit and the search had remained within the bounds intended by the magistrate. Id. at 560-61. The majority opinion rejected this argument partly on the ground that the warrant in the case totally failed to satisfy the assurance function, which the Court treated as an important purpose of the particularity requirement. Id. at 561-62 \& n.5. In dissent, Justice Thomas belittled this argument, noting that "neither the Fourth Amendment nor Federal Rule of Criminal Procedure 41 requires an officer to serve the warrant on the searchee before the search." Id. at 577 (Thomas, J., dissenting). In the Ninth Circuit panel opinion affirmed by Groh, Judge Kozinski suggested that the particularity requirement also serves to enable the search target to monitor the conduct of the search to ensure that it stays within the bounds set by the magistrate, and concluded that the warrant in question totally failed to serve this "monitoring" function. Ramirez $\mathrm{v}$. Butte-Silver Bow County, 298 F.3d 1022, 1027 (9th Cir. 2002) aff'd sub nom., Groh v. Ramirez, 540 U.S. 551 (2004). But cf. Stefonek, 179 F.3d at 1034-35 (rejecting the argument that the particularity requirement serves a monitoring function and instead suggesting that the assurance function of warrants is designed only "to head off breaches of the peace by dispelling any suggestion that the search is illegitimate").

325. Again, Groh is a good example. There, the Court held that a particularity defect on the face of the warrant rendered a search invalid even though the warrant application made it clear that the officers executed the search in accordance with the magistrate's intentions and that probable cause supported the scope of the search the magistrate intended to authorize. 
blank slate, I would ask how the various possible approaches to the use of suppression hearing testimony in the good-faith inquiry might affect the likelihood that magistrates will exercise the kind of judgment envisioned by Justice Jackson. For example, one might reasonably wonder whether magistrates would relax their scrutiny of warrant applications if they knew any errors they failed to catch could later be remedied by suppression hearing testimony. Whatever force this line of thought might have in the abstract, Leon renders it irrelevant by assuming that magistrates are not influenced by the prospect that evidence will be suppressed. ${ }^{326}$ In any event, the issue considered in this Article arises only when the magistrate has already failed to serve her proper function because she was willing to approve a search based on information so lacking in probable cause that reasonable officers should have recognized the error. We are therefore limited to examining how the various approaches to the use of suppression hearing testimony might affect the other ways in which the warrant requirement serves to prevent bad searches: the protections created by the discipline of the warrant application process and the record it creates. It is these functions of the warrant process that are most sharply implicated by the issue of whether suppression hearing testimony can be used to establish an officer's good faith. Evaluation of the various possible approaches to the issue should turn, then, on their effects on these functions. I begin by examining each function in turn.

\section{How Warrants Help Curb Police Perjury}

Police perjury is, of course, an extremely serious problem because it undermines all the protections of the Fourth Amendment. ${ }^{327}$ Though it is, for obvious reasons, difficult to know the exact scope of the problem, there is wide agreement that the problem is real. ${ }^{328}$ Many scholars have

326. United States v. Leon, 468 U.S. 897, 916-17 (1984). The majority was unmoved by Justice Brennan's arguments in dissent that magistrates would have less incentive to attend to the warrant process if they knew that their errors would usually have no consequences under Leon. $1 d$. at 956 (Brennan, J., dissenting).

327. See Stuntz, supra note 317 , at 916 ("Where perjury is successful, no substantive standard constrains police decisions to search. The only constraint left is the officer's ability and willingness to concoct a good story.").

328. See, e.g., Myron W. Orfield, Jr., Deterrence, Perjury, and the Heater Factor: An Exclusionary Rule in Chicago Criminal Courts, 63 U. Colo. L. REV. 75, 107 (1992) (survey suggesting that between twenty and fifty percent of prosecutors, defense attomeys, and judges believe perjury is commonplace at suppression hearings). For further discussions of the problem of police perjury, see generally Morgan Cloud, The Dirty Little Secret, 43 EMORY L.J. 1311 (1994); Morgan Cloud, Judges, "Testilying," and the Constitution, 69 S. CAL. L. REV. 1341 (1996); David N. Dorfman, Proving the Lie: Litigating Police Credibility, 26 AM. J. CRIM. L. 455 (1999); Donald 
made suggestions about how to reduce the frequency of police perjury; ${ }^{329}$ one of the most common suggestions is increasing the scope of the warrant requirement. ${ }^{330}$

To appreciate why warrants are commonly thought to reduce police perjury, consider the typical differences between judicial review of warrant and warrantless searches. In the case of a warrantless search, the first judicial determination of probable cause comes in the context of a suppression hearing. ${ }^{331}$ As Professor Stuntz has explained, the dynamics of the suppression hearing tend to facilitate police perjury in several ways. ${ }^{332}$ In deciding the suppression motion in a warrantless search case, the trial court must decide (1) whether to believe the officer's testimony about his grounds for conducting the search, and (2) whether that testimony, if believed, is sufficient to show that the officer had probable cause for the search. ${ }^{333}$ In deciding whether the police officer's testimony about his basis for the search is believable, the court faces an enormous "credibility gap" between the police officer and the defendant who would challenge the officer's testimony. By definition, police have uncovered incriminating evidence that often indicates the defendant's probable guilt. ${ }^{334}$ This means that the defendant has an overwhelming incentive to lie, and often his character has already been called into doubt by the evidence presented against him. ${ }^{335}$ This credibility gap tempts

A. Dripps, Police, Plus Perjury, Equals Polygraphy, 86 J. CRIM. L. \& CRIMINology 693 (1996); Stanley Z. Fisher, "Just the Facts, Ma'am": Lying and the Omission of Exculpatory Evidence in Police Reports, 28 New ENG. L. Rev. 1 (1993); Christopher Slobogin, Testilying: Police Perjury and What to Do About It, 67 U. COLO. L. REV. 1037 (1996); Myron W. Orfield, Jr., Comment, The Exclusionary Rule and Deterrence: An Empirical Study of Chicago Narcotics Officers, 54 U. CHI. L. REV. 1016 (1987).

329. See, e.g., Dorfman, supra note 328, at 491-502 (advocating more aggressive exploration of police credibility on cross examination); Dripps, supra note 328, at 693-94 (advocating use of polygraphy).

330. See Cloud, Dirty Little Secret, supra note 328, at 1347 (discussing how rigorous enforcement of the warrant requirement could limit police perjury); Stuntz, supra note 317 , at 915 (explaining how the warrant requirement makes perjury more difficult).

331. Sometimes, though rarely, the first judicial examination of probable cause for a warrantless search will arise in the context of an action for damages under 42 U.S.C. $\$ 1983$ (2000). My discussion here focuses on the more usual context in which the forum of review is a suppression hearing.

332. Stuntz, supra note 317 , at 914-15.

333. Obviously, other issues (e.g., consent) requiring credibility judgments can arise in suppression hearings. Focusing on review of the officer's probable-cause judgment best serves the purposes of this Article.

334. See Stuntz, supra note 317 , at 912 ("One of the prerequisites for the defendant's fourth amendment claim - the existence of suppressible evidence of crime-tends to suggest that the defendant deserves punishment, not relief.").

335. Id. at 914. As Stuntz points out, judges recognize that police officers may also have 
police to lie by making it easy for them to do so effectively. ${ }^{336}$ In addition, a police officer at a suppression hearing may be especially willing to lie to save the fruits of a search because the officer's suspicions (whatever their original basis) have turned out to be justified. ${ }^{337}$ Finally, judges may be especially reluctant to discredit an officer's testimony when the cost may be the release of a guilty defendant. ${ }^{338}$

In warrant searches, on the other hand, a judicial officer first rules on the propriety of a search before it takes place. The ex ante character of the warrant process works to reduce the likelihood of police perjury in several ways. First, and most significantly, the warrant requirement makes perjury more difficult by making it easier to detect. Because the process of applying for a warrant forces officers to commit to a story before they know all the evidence that ultimately will bear on the case (both from the search itself and from other sources not yet identified), they have a harder time lying in a way that will ultimately prove credible. ${ }^{339}$ Second, warrants may make perjury harder because a magistrate ruling on a warrant application must judge the credibility of the officer's story without knowing whether the requested search will actually prove fruitful. In contrast, a judge evaluating police credibility at a suppression hearing is likely to be influenced by the credibility gap discussed above. ${ }^{340}$ Third, it may be the case that police are less willing to lie to a magistrate than in a suppression hearing because they do not yet know whether the target of the requested search is a criminal. In other words, the motivation to lie may be greater when the cost of

motives to lie. In the ordinary case, however, these motives seem significantly weaker than the defendant's motives and hence the credibility gap remains. $I d$.

336. Id. at 914-15.

337. Id. at $915 \& \mathrm{n} .75$.

338. The idea that judges may be reluctant to enforce the exclusionary rule because its most visible beneficiaries are the guilty is commonplace in the scholarly literature. See, e.g., Dorfman, supra note 328, at 470-73; Mertens \& Wasserstrom, Deregulating the Police, supra note 8, at 449.

339. See Stuntz, supra note 317 , at 915 (stating that the warrant requirement makes perjury more difficult "since the officer cannot so easily manufacture details consistent with a story he does not yet know"); see also Bradley, supra note 207, at 292 (stating that warrants "make it more difficult for the police to fabricate probable cause on the basis of what was found instead of what was actually known in advance").

340. The point is admittedly speculative. On the one hand, an implausible account from an officer is easier to discredit when the judge does not yet know that the cost of disbelief may be the loss of a conviction - especially when disapproving the warrant application may simply prompt the police to conduct a more thorough investigation. On the other hand, the casual ex parte character of the warrant process may impart a pro-government bias to magisterial review of warrant applications. See Stuntz, supra note 317, at 891. 
truthfulness is the release of the guilty rather than a refusal of permission to search the possibly guilty. ${ }^{341}$

If warrants generally make police perjury more difficult, what does this imply about using suppression hearing testimony to establish the officer's good faith? Under the approach taken by the Ninth Circuit, the perjury protections of the warrant process would be fully operative because there would be no opportunity to supplement the probable-cause showing made to the magistrate with post hoc testimony supporting probable cause. In contrast, allowing suppression hearing testimony to supplement the showing made to the magistrate might partially reintroduce the temptations to perjury that the warrant process ordinarily helps to curtail. ${ }^{342}$ The officer would have the advantage of being able to tailor his testimony to all the evidence, the advantage of the credibility gap and hindsight bias, and a strong motive to lie. On the other hand, allowing suppression hearing testimony to cure probable-cause deficiencies would not completely eliminate the perjury-reducing effects of the warrant requirement. Unlike the situation with a warrantless search, the officer who seeks to establish his good faith through suppression hearing testimony has already gone on record about the circumstances justifying the search in the warrant application. This creates some constraints on post hoc tailoring of testimony that are not present in a warrantless search. Still, it seems plausible to think that allowing suppression hearing testimony to cure probable-cause deficiencies in the affidavit would lessen the warrant requirement's protections against perjury at least to some extent. The difficult question is whether that price is worth paying.

\section{How the Warrant Application Process Deters Bad Searches}

As Donald Dripps has emphasized, the discipline of the warrant application process may operate to prevent bad searches even when

341. Id. at 915 n.75.

342. Even courts taking a permissive attitude toward suppression hearing testimony retain some check on perjury. In determining whether information never presented to the magistrate proves the officer's good faith, the trial court must still decide whether the officer is being truthful about what she knew at the time of the warrant application. If the trial judge disbelieves the officer's post hoc testimony-which sometimes happens, see Orfield, Heater Factor, supra note 328, at 107-08 (discussing survey evidence suggesting that when judges grant suppression motions, it is often because they disbelieve the officer's story--she will disregard it and the evidence will be suppressed. This kind of perjury check, however, is present even in warrantless searches. The warrant process is supposed to provide additional checks against perjury. For my purposes, the relevant question is how much these additional checks would be undermined if suppression hearing testimony were allowed to establish an officer's good faith under Leon. 
magistrate review is cursory. ${ }^{343}$ As Dripps points out, the existing empirical studies on the warrant process indicate that warrant searches tend to uncover evidence of crime in the vast majority of cases. ${ }^{344}$ This fact suggests that the warrant process is genuinely effective in protecting citizen privacy.

One possible explanation for the fruitfulness of warrant searches is that magistrates are doing a good job of screening out bad warrant requests and insisting that officers make a strong showing of probable cause in their warrant applications. There are a number of reasons, however, to doubt this theory. First, the casual, ex parte character of the warrant application process is ill-suited to produce searching reviews of warrant applications. ${ }^{345}$ Second, existing empirical evidence suggests that magistrate review of warrant applications is often superficial. A 1985 study by the National Center for State Courts found that magistrates spent a median time of two minutes and twelve seconds reviewing each warrant application. ${ }^{346}$ Frequently, the magistrate failed to ask the officer even a single question about the application. ${ }^{347}$ It also appears that, contrary to the Supreme Court's claims in Leon, ${ }^{348}$ some magistrates do see themselves as part of law enforcement. ${ }^{349}$ Third, the case law records numerous instances in which magistrates have been disturbingly lax in their reviews of warrant applications. ${ }^{350}$ Finally, many magistrates lack

343. Dripps, supra note 8, at 923-33.

344. Id. at 925 (citing NCSC Study, supra note 80 , for the proposition that in six of seven cities studied, between seventy-four and eighty-nine percent of warrant searches discovered at least some of the evidence named in the warrant).

345. See United States v. Leon, 468 U.S. 897,970 n.22 (Stevens, J., dissenting) (stating that magistrate determinations of probable cause "partake[] of the unreliability inherent in any ex parte proceeding").

346. See NCSC Study, supra note 80 , at 26-27 (reporting that magistrates spent more than five minutes reviewing warrant applications in only eleven percent of the cases and rejected only eight percent of the applications presented).

347. Id. at 26. In addition, many of the questions magistrates did ask sought information already contained in the warrant application. Id. at 49 . Professor Duke has suggested this "implies that the magistrate asked the question as a substitute for reading the application." Steven Duke, Making Leon Worse, 95 YALE L.J. 1405, 1408 (1986). Duke also points out that, if anything, the data from the NCSC Study present an unrealistically favorable portrait of magisterial review because the magistrates at the study site knew they were being observed. $I d$. at 1408 n.26.

348. 468 U.S. at 917 (emphasizing that magistrates are not "adjuncts to the law enforcement team" and therefore "have no stake in the outcome of particular criminal prosecutions").

349. See NCSC Study, supra note 80, at xi (reporting finding in survey of Virginia magistrates that $11.4 \%$ of interviewed magistrates thought that they should generally grant warrant requests because " "police have the best knowledge of the facts of the case"" (quoting NATIONAL CENTER FOR STATE COURTS, VIRGINIA ORGANIZATION STUDY 16 (1979))); id. at 47, 95 (reporting anecdotal evidence that some magistrates see their role as one of assisting the police).

350. See, e.g., United States v. Martin, 297 F.3d 1308, 1312, 1320-2l (11 th Cir. 2002) (applying Leon despite issuing judge's admission that he did not inquire about the possible staleness of the 
legal training and so are reluctant to second guess police officers' probable-cause judgments, especially when those judgments have been pre-screened by prosecuting attorneys. ${ }^{351}$ It is hardly surprising, then, that some commentators have described the " rubber stamp' quality of magistrate review of warrant applications" as an "open scandal.",352 While the empirical data is too sparse to be conclusive, there is surely reason to doubt whether magistrates are responsible for the apparent effectiveness of the warrant process in insuring that searches are productive.

An alternative explanation, promoted most vigorously by Professor Dripps, is that the costs of the warrant application process lead police to screen warrant searches for probable cause more rigorously than they screen warrantless searches. ${ }^{353}$ Because police must often go to considerable time and trouble to obtain a warrant, ${ }^{354}$ they will not try to

information supporting probable cause because he had signed warrants for the affiant for years and therefore "'wouldn't expect him to bring me a stale warrant"); United States v. Decker, 956 F.2d 773, 777 (8th Cir. 1992) (suppressing evidence where magistrate signed the warrant without reading it); United States v. Breckenridge, 782 F.2d 1317, 1321-22 (5th Cir. 1986) (applying Leon even though the magistrate failed to read the supporting affidavit because it appeared to the officers that the magistrate was acting in a "neutral and detached" manner).

351. See Goldstein, supra note 37, at 1183-87 (discussing the required qualifications for magistrates). In Shadwick v. City of Tampa, 407 U.S. 345, 350-52 (1972), the Supreme Court rejected a constitutional challenge to an ordinance permitting non-lawyer municipal court clerks to issue certain arrest warrants. For a particularly colorful account of magistrates' limitations, see State v. Adkins, 346 S.E.2d 762, 777-78 (W. Va. 1986) (Neely, J., concurring in part and dissenting in part) (arguing that it is unfair to hold state magistrates to the standards of federal magistrates because their levels of education, training, and pay are so much lower).

352. Wasserstrom \& Seidman, supra note 311 , at 34.

353. See Dripps, supra note 8, at 923-33 ("What we know about search warrants strongly suggests that [the costs of obtaining warrants], and not the exclusionary rule, explain the surprising success of the warrant process.").

354. According to the NCSC Study, supra note 80 , at 19, 66-68, officers view the time and hassle involved in the warrant process as a significant disincentive. As one officer put it, "search warrants are double the time, sometimes triple the time that you take on arrest warrants, and arrest warrants are long enough. Arrest warrants, you figure half a day." Id. at 19. Courts report the average time required to get a warrant as between two and four hours. Sklansky, supra note 101, at 1252 \& n.69 (collecting cases). The perceived hassle of getting a warrant may, of course, lead police to rely on exceptions to the warrant requirement (e.g., exceptions for consent and exigent circumstances). See NCSC Study, supra note 80, at 19 (quoting officer's claim that because of the hassle of obtaining a warrant, the officer tried in the first instance to "work some other method" such as obtaining consent to search). Yet when a warrant is the only legal route, as it often is when police seek to search a suspect's residence, the costs of the warrant process work to significantly deter police from undertaking speculative searches.

Although allowing telephonic warrants might reduce the time and difficulty of obtaining a warrant, so far relatively few jurisdictions have approved such a procedure. See Sklansky, supra note 101, at 1249-59. Whether telephonic warrants are, on the whole, a good thing depends on the quality of the magistrate's review. To the extent magistrates can be trusted to perform a searching ex ante review, telephonic warrants probably increase citizen privacy by increasing the number of 
do so unless they have a relatively high degree of certainty that the search will be fruitful. ${ }^{355}$ This means that even if magistrate review is usually cursory, the warrant process can still protect privacy by leading police to discipline themselves. ${ }^{356}$

Dripps's explanation for the high success rate of warrant searches emphasizes the mundane realities of the search warrant application process: filling out paperwork, waiting for an available magistrate, etc. These "queuing costs" may be an important part of the protection provided by the warrant requirement because any obstacles that increase the costs of searching make it somewhat less likely that police will search on an inadequate basis. In addition to these queuing costs, however, the process of preparing a warrant application also imposes on police officers the valuable discipline of having to sit down and write out precisely why they believe they have probable cause to search. ${ }^{357}$ Perhaps the effort to justify a search to a neutral third party causes police to exercise greater care in their own probable-cause judgments. ${ }^{358}$

searches that will be vetted by the warrant process. To the extent that magistrate review is perfunctory and the primary protection of the warrant process is self-imposed, telephonic warrants may reduce citizen privacy by lowering the costs of the warrant process. For further discussion of telephonic warrants, see generally Donald L. Beci, Fidelity to the Warrant Clause: Using Magistrates, Incentives, and Telecommunications Technology to Reinvigorate Fourth Amendment Jurisprudence, 73 DENV. U. L. REV. 293 (1996); Justin H. Smith, Note, Press One for Warrant: Reinventing the Fourth Amendment's Search Warrant Requirement Through Electronic Procedures, 55 VAND. L. REV. 1591 (2002).

355. The statement in the text oversimplifies to some degree. In investigations of certain crimes-e.g., the murder of a fellow police officer-the perceived importance of gathering evidence is so great that police may be willing to incur the costs of the warrant process even when the probability of discovering evidence is relatively low. See Dripps, supra note 8, at 925-26 n.18. Such cases are relatively rare, however, and can be seen as exceptions that prove the rule.

356. For this reason, Professor Dripps's assessment of Leon was less dire than most other reactions at the time. Compare id. at 928 (suggesting that "Leon probably will not have much deleterious impact on police willingness to seek dubious warrants" because "[a]bsent a strong expectation of success, the police will not undertake the cost") with United States v. Leon, 468 U.S. 897, 929 (1984) (Brennan, J., dissenting) (memorably remarking that in light of the Leon decision, "[i]t now appears that the Court's victory over the Fourth Amendment is complete").

357. See Bradley, supra note 207, at 292 (describing as "the most important aspect of the warrant" the fact "that it forces the police to stop, think, write down their evidence, and submit it to someone else for approval"); Goldstein, supra note 37, at 1182 (stating that the NCSC Study found that "going through the process of filling out a warrant application, and thinking through the factors upon which an assessment of probable cause will be based, forces the police to take the probable cause requirement, and thus the right to privacy, more seriously"); Christopher Slobogin, An Empirically Based Comparison of American and European Regulatory Approaches to Police Regulation, 22 MiCH. J. INT'L L. 423, 437 (2001) (citing the NCSC Study in support of the claim that research "firmly suggest[s]" that "warrants raise police officers" 'standard of care' when they decide whether to conduct a search").

358. Privacy is further enhanced when pre-screening by a prosecutor is a standard part of the warrant application process. See Dripps, supra note 8, at 930 (explaining how pre-screening 
In sum, both the queuing costs of the warrant process and the discipline of filling out the warrant application may protect privacy by leading police to constrain themselves. This self-restraint may help to protect citizen privacy to some degree even when the magistrate does not live up to the job description Justice Jackson envisioned. ${ }^{359}$ It follows that even in cases where the magistrate has issued a warrant based on an affidavit falling far short of probable cause, we still need to ask how allowing suppression hearing testimony to cure probable-cause deficiencies will affect the Fourth Amendment protections that officers impose on themselves through the warrant application process.

\section{Framing the Possible Rules for the Use of Suppression Hearing Testimony to Establish Good Faith}

To briefly summarize the argument so far, the proper question to ask in assessing the officer's good faith under Leon is whether the officer could have entertained an objectively reasonable belief that the warrant was properly issued. This way of posing the question makes it clear that the officer has an obligation to assure himself that the magistrate has properly performed her role, an obligation that requires the officer to look at the process from the magistrate's point of view. Deciding whether a magistrate acted properly in issuing a warrant requires, among other things, that the officer ask himself whether the magistrate's probable-cause determination was reasonable in light of the materials presented to her. This means that information not presented to the magistrate can only be relevant to the officer's good faith if the officer actually believed that he told the magistrate all he knew. In other words, suppression hearing testimony can be relevant to the good-faith question only if the officer made a mistake about what he put in front of the magistrate. The real question, then, is whether this kind of mistake can ever be regarded as objectively reasonable under Leon. I have suggested that we should evaluate the possible answers to this question by examining their potential effects on the two privacy-protection functions the warrant process still serves even when the magistrate has failed to properly perform her role: checking police perjury and encouraging

procedures improve the reliability of warrants); NCSC Study, supra note 80, at 20-21 (noting that prosecutorial pre-screening of warrant applications is one benefit of the warrant process).

359. There is no doubt some interdependence here. If officers think that magistrate scrutiny of warrant applications will be cursory and that magistrate decisions are essentially unreviewable, they will not feel a great deal of pressure to convincingly articulate their grounds for finding probable cause in their warrant applications. 
greater self-restraint by officers. (For ease of exposition, I shall refer to these two aspects of the analysis as the "perjury variable" and the "discipline of the warrant process" variable.) These are the protections that might be lost if courts allow suppression hearing testimony to establish the officer's good faith.

As I noted above, anything less than a bright-line rule against the use of suppression hearing testimony in the good-faith inquiry threatens to lessen these protections to some degree. It might seem, then, that my analysis points inexorably toward the ultimate embrace of the Ninth Circuit view. But matters are not so simple as that. For one thing, Leon counsels against bright-line rules in this area, insisting that suppression where the officer has obtained a warrant should be ordered only on a case-by-case basis. ${ }^{360}$ More significantly, there are law enforcement costs on the other side of the ledger that must be considered as well. If the point of the exclusionary rule is to protect privacy by changing police behavior, one must also consider that any bright-line rule will sometimes result in the exclusion of evidence when neither perjury prevention nor care in the warrant process are implicated. A closer look, then, is required.

There are three possible positions with respect to both the perjury variable and the discipline of the warrant process variable. With respect to the perjury variable, the first approach would adopt a bright-line rule against using suppression hearing testimony to rehabilitate deficient affidavits. A second, permissive approach would allow the use of suppression hearing testimony so long as the government could convince the court that the testimony was truthful by a preponderance of the evidence. A third approach would allow the use of suppression hearing testimony subject to some heightened proof standard, such as clear and convincing evidence. The possible approaches to the discipline in the warrant process variable are distinguished by their different answers to the question of what counts as a reasonable mistake in the warrant application process. Under the first approach, there would be no such thing as a reasonable mistake and police officers would essentially be required to achieve perfection in the warrant application process. A second approach would say that any inadvertent mistake counted as reasonable. A third approach would impose a duty of reasonable care in the warrant process while recognizing the possibility of objectively reasonable mistakes that need not result in the suppression of evidence.

360. See Leon, 486 U.S. at 918 (stating that suppression of evidence secured under the authority of a warrant "should be ordered only on a case-by-case basis and only in those unusual cases in which exclusion will further the purposes of the exclusionary rule"). 
Putting together the options for both variables suggests the following five possible rules:

(1) Suppression hearing testimony can be used to establish the officer's good faith if the omission from the affidavit was inadvertent and the prosecution can prove by a preponderance of the evidence that the information was known to the affiant at the time of the warrant application. ${ }^{361}$

(2) Suppression hearing testimony can be used to establish the officer's good faith if the omission from the affidavit was inadvertent and the prosecution can prove by clear and convincing evidence that the information was known to the affiant at the time of the warrant application. ${ }^{362}$

(3) Suppression hearing testimony can be used to establish the officer's good faith if the omission resulted from a reasonable mistake and the prosecution can prove by a preponderance of the evidence that the information was known to the affiant at the time of the warrant application. ${ }^{363}$

(4) Suppression hearing testimony can be used to establish the officer's good faith if the omission resulted from a reasonable mistake and the prosecution can prove by clear and convincing evidence that the information was known to the affiant at the time of the warrant application. ${ }^{364}$

(5) Suppression hearing testimony can never be used to establish the officer's good faith. ${ }^{365}$

It will, I hope, be apparent that option (1) is essentially a reconstructed $^{366}$ version of the Eighth Circuit view, while option (5) is essentially the Ninth Circuit view. While the Eighth Circuit takes a

361. In other words, Leon would apply to all but Type I cases so long as the trial court believes the suppression hearing testimony.

362. In other words, Leon would apply to all but Type I cases so long as the truthfulness of the suppression hearing testimony is proven by clear and convincing evidence.

363. In other words, Leon would apply only in Type III and IV cases so long as the trial court believes the suppression hearing testimony.

364. In other words, Leon would apply only in Type III and IV cases so long as the truthfulness of the suppression hearing testimony is proven by clear and convincing evidence.

365. In other words, Leon would never apply in any case where the materials presented to the magistrate were insufficient to support reasonable reliance by the officer.

366. I say "reconstructed" because some of the language in cases adopting the Eighth Circuit view implies that information not presented to the magistrate can always be used to establish good faith. For reasons explained earlier, see supra note 204 and accompanying text, I doubt that any court would go so far in practice. 
minimalist approach to both variables, the Ninth Circuit takes a maximalist approach. I believe that the fourth option is the most appropriate approach within the framework created by Leon. Courts should allow the use of suppression hearing testimony to rehabilitate a deficient affidavit under Leon only if the omission resulted from a reasonable mistake in preparing the warrant application and the officer's knowledge at the time of the warrant application is proven by clear and convincing evidence. In explaining my reasons for this position, I shall begin with discussion of the discipline of the warrant process variable and then move on to discuss remaining questions about perjury. ${ }^{367}$

\section{A Duty of Reasonable Care in the Warrant Application Process}

The options here are (1) regarding all mistakes in the warrant application process as unreasonable, (2) regarding all inadvertent errors as reasonable, and (3) distinguishing between reasonable and unreasonable mistakes. In arguing for the third, middle path, the challenge is to counter objections from both sides.

\section{Why There Must Be Some Duty of Care}

The Eighth Circuit approach takes the position that so long as the suppression hearing testimony is truthful and the officer actually had probable cause for the search at the time of the warrant application, there

367. The options described above leave out one possibility that some might find attractive. Whereas the critical line in my position is that between Type II and Type III cases, one might instead attempt to draw the critical line between Type III minor omission cases and Type IV pure transmission error cases. This approach would distinguish those cases where the officer's error was insufficient attention to all the elements of probable cause from those where the only error was in the mechanical process of filling out forms. It might be thought that errors in the process of thinking critically about whether the evidence amounts to probable cause are more culpable than pure transmission errors, and also more likely to be prevented by increased training. I see two problems with this approach. First, I find it difficult to regard the officer errors in cases like Procopio as much more culpable or preventable than those in pure transmission error cases. Second, there will often be no evidence beyond the officer's post hoc testimony that courts could use to draw the line between Type III and Type IV cases. Courts should not be asked to administer a line that turns on the difference between post hoc testimony stating, "I thought about the staleness issue but forgot to put my conclusions in the affidavit," and post hoc testimony stating, "I assumed the evidence was not stale, but never really thought about the basis for my conclusion." The only administrable line between Type III and Type IV cases would require that the transmission error be proved by "objective circumstances" (e.g., the initial arrest warrant application in Corrigan) rather "the officer's post hoc testimony as to his state of mind." People v. Deitchman, 695 P.2d 1146, $1160 \mathrm{n} .4$ (Colo. 1985) (en banc) (Dubofsky, J., concurring). That line, though administrable, would be barely distinguishable in practice from the Ninth Circuit view because "objective circumstances" proving transmission error will seldom exist. 
is no point in suppressing evidence. ${ }^{368}$ In such a case, the officer has done an adequate investigation and has secured a warrant by submitting an affidavit that exceeded the bare-bones standard. By hypothesis, the officer's only shortcoming is that he should have been more careful in preparing the warrant application. The Eighth Circuit position asks why we should care that the officer did a poor job of filling out forms, and implies that the question has no answer. This position has intuitive appeal for a number of reasons.

First, mistakes - even fairly significant mistakes-in filling out the warrant application do not seem like the sort of police misconduct the exclusionary rule was meant to deter. Though the Court has allowed for the possibility that negligent police errors might still warrant suppression, ${ }^{369}$ the errors in some cases (e.g., Corrigan ${ }^{370}$ and Procopio $^{371}$ ) seem so innocuous that it is difficult to muster any moral indignation about them.

Second, some errors in the warrant application process are likely ineliminable by even the most rigorous training programs. As Justice Kennedy pointed out in his dissenting opinion in Groh, "[w]e all tend toward myopia when looking for our own errors. Every lawyer and every judge can recite examples of documents that they wrote, checked, and double checked, but that still contained glaring errors. Law enforcement officers are no different." 372 Can one really imagine, for example, that the officer in Corrigan would have remembered to address staleness in the search-warrant application if he had been trained more comprehensively in Fourth Amendment requirements? ${ }^{373}$ Because Leon teaches that suppression is only appropriate when it will have some effect on the conduct of individual police officers or their departments, ${ }^{374}$ suppression makes no sense in the case of ineliminable errors because the costs of exclusion would necessarily trump the deterrence benefits.

Third, inadvertent omissions in the warrant application process do not seem to threaten substantive Fourth Amendment rights so long as the

368. See supra Part III.A (discussing the Eighth Circuit approach).

369. Groh v. Ramirez, 540 U.S. 551, 565 (2004) (rejecting officer's argument that merely negligent police errors should automatically be entitled to qualified immunity). Because the standards for qualified immunity and the good faith exception are the same, Malley v. Briggs, 475 U.S. 335, 344 (1986), Groh means negligent police errors can warrant suppression.

370. United States v. Corrigan, 809 F. Supp 567 (M.D. Tenn 1992).

371. United States v. Procopio, 88 F.3d 21 (1st Cir. 1996).

372. Groh, 540 U.S. at 568 (Kennedy, J., dissenting). See also Alschuler, supra note 19, at 345 (observing that "the prospect of exclusion seems very unlikely to reduce the chance that an official would carelessly overlook the critical language of a warrant when he sought to alter it").

373. For discussion of the facts of Corrigan, see supra notes 293-301 and accompanying text.

374. See United States v. Leon, 468 U.S. 897, 918 (1984). 
police officer really had probable cause for the search. The person searched would seem to be no worse off than if the police had used greater care in putting together the warrant application. Nor can the search target complain about the loss of any procedural rights because the officer, after all, did use the proper channels by applying for the warrant in the first place. Indeed, strict application of the exclusionary rule in an inadvertent omission case threatens to penalize the officer for the ex parte character of the warrant process. If it were possible to test the warrant application by an adversarial process before the search, the application's shortcomings would presumably be identified and the officer could fill in the gaps. Informed, skeptical questioning by the magistrate is supposed to substitute for the adversarial process, but that sort of questioning occurs all too seldom. In sum, the distinctive feature of cases where the officer omits information supporting probable cause from the warrant application is that the officer's error is of a sort that is made possible by the warrant requirement and would not exist without it. Where the error could have been corrected through vigilant scrutiny of the affidavit and warrant by the magistrate, suppressing the evidence appears to penalize the officer for the ex parte character of the process. From this point of view, it is understandable that some courts are tempted to lay all blame at the feet of the magistrate.

Nonetheless, there are reasons for imposing (at the very least) some duty of reasonable care in the warrant application process. As we have already seen, the warrant application process works to protect privacy by leading officers to police themselves. The costs of obtaining a warrant and the discipline of having to articulate in writing one's basis for a search likely cut off many bad searches before the officer ever gets to the magistrate. ${ }^{375}$ This, as Professor Dripps has explained, is a plausible explanation for the high success rate of warrant searches. ${ }^{376}$ A rule forgiving any inadvertent omission works to undermine this protection by telling officers that the application process does not matter.

While it is true that some types of errors in the warrant application process are probably ineliminable, not all are. Indeed, the distinction between Type II cases (like the Eighth Circuit's Martin case and Carpenter) and Type III cases is principally one between errors in the application process that can be influenced by training and those that cannot. Where an officer fails altogether to address some critical element of the probable-cause showing, such as the requirement of a

375. See Dripps, supra note 8, at $923-33$.

376. Id. 
nexus between the place to be searched and criminal activity, the officer has not approached the task of demonstrating probable cause with sufficient seriousness and thus has compromised one of the protections of the warrant process. A mistake in the warrant process that reflects a cavalier approach should not count as objectively reasonable even if the officer actually had probable cause for the search at the time of the warrant application. Thus suppression is still appropriate in Type II cases. This means that there are cases in which courts should suppress evidence because of an officer's carelessness in the warrant application process even though they are convinced that the officer actually had probable cause for the search at the time of the warrant application. Courts would not relish this prospect, especially in "heater" cases, ${ }^{377}$ but the alternative would significantly undermine the integrity of the warrant process by telling police officers that a warrant is nothing more than a piece of paper. The Eighth Circuit-style rule of excusing all inadvertent omissions from the warrant application exacerbates the "lack of acoustic separation" problem discussed in Part II. ${ }^{378}$ To the extent officers hear the message that ordinary carelessness has no consequences, the selfimposed protections of the warrant process emphasized by Dripps wither away.

Once it is recognized that there must be some duty of reasonable care in the warrant application process and that not all mistakes count as reasonable, the obvious question is where and how to draw the line between the reasonable and the unreasonable mistakes. I return to that question below, but I first address a challenge to my position that comes from the opposite side. Why, it may be asked, should the law recognize the existence of objectively reasonable mistakes in the warrant application process? Why should an officer's failure to recognize a gap between her information supporting probable cause and her warrant application ever count as reasonable?

377. A "heater case" is one involving a great deal of public or departmental pressure to find the criminal and secure a conviction. See Orfield, Heater Factor, supra note 328, at 116-17. The murder of a police officer or public figure is a paradigmatic heater case. According to Orfield's Chicago field study, both officers and judges agree that judicial commitment to Fourth Amendment values sometimes wavers in heater cases. Id. at 117-19.

378. See supra notes $87-107$ and accompanying text. 
2. Why Perfection is the Wrong Standard for Police Officers Even if it is the Right Standard for Police Clerks

The Ninth Circuit approach would answer these questions by saying that officers cannot make reasonable mistakes about the contents of their warrant applications. In other words, a reasonably well-trained officer would always manage to tell the magistrate everything that she knew and would scrutinize the warrant application carefully enough to recognize any gaps and fill them in. At first glance, this argument might seem a bit strange. We naturally resonate with Justice Kennedy's observation that even the most careful among us will not detect every error. ${ }^{379}$ Further, the existing law of probable cause and good faith seems already to incorporate the notion of reasonable mistake. An officer can have probable cause for a search even though she is reasonably mistaken about one of the factual assumptions justifying the search, ${ }^{380}$ and Leon allows both magistrates and police officers to make reasonable mistakes about whether a given set of facts satisfies the legal concept of probable cause. ${ }^{381}$ Why, then, should we expect an officer to be perfect when it comes to filling out and/or proofreading warrant applications? Nonetheless, the Ninth Circuit's refusal to recognize objectively reasonable mistakes in the warrant application process cannot be so easily dismissed.

First of all, there are circumstances in which the law defines the level of reasonable care as perfection. For example, Professor Grady's work calls attention to the "no-forgetting" rule in tort law, which holds that the reasonable person always remembers to take cost-justified precautions. ${ }^{382}$ Prevailing tort doctrine thus teaches that "if it is reasonable on a single occasion to check a dial or look for a train, it is reasonable on all occasions to do so." ${ }^{.383}$ According to Grady, this noforgetting rule is problematic because it ignores some of the costs of careful behavior. ${ }^{384}$ In economic terms, the costs of using "nondurable

379. See Groh v. Ramirez, 540 U.S. 551, 568 (Kennedy, J., dissenting).

380. See Alschuler, supra note 19 at 331-32 (explaining that the concept of probable cause already makes allowance for reasonable-factual mistakes by law enforcement officers). But cf. supra note 219 (acknowledging that the analogy between reasonable mistakes in the probable-cause context and reasonable mistakes in the warrant application is not perfect).

381. United States v. Leon, 468 U.S. 897, 922 (1984).

382. Mark Grady, Why are People Negligent? Technology, Nondurable Precautions, and the Medical Malpractice Explosion, 82 NW. U. L. REV. 293, 302-10 (1988).

383. Id. at 306 .

384. Id. 
precautions" ${ }^{385}$ such as remembering to signal and check the blind spot before changing lanes include both "precaution costs" (the burdens of looking over the shoulder and turning on the signal) and "compliance costs" (the burdens of remembering and noticing to signal and check the blind spot). ${ }^{386}$ Because remembering to use a precaution, like anything else, has a cost, Grady argues that the economically rational rate of compliance will be something less than one hundred percent and that the no-forgetting rule creates a pocket of strict liability within negligence law. ${ }^{387}$ Stripped of the economic trappings, the point is that even though human beings do not seem capable of perfect attentiveness, the law nonetheless demands perfection. That sounds unfair, but the rule may be justified because too little attentiveness poses undue risks of harm to others and there is no way courts can reliably decide which individual episodes of inattentiveness were reasonable and which were not. As Grady explains,

If courts allowed forgetfulness as a defense, everyone would maintain that he forgot. It requires much less information for courts to see whether a signal was given on a particular occasion than it does for them to assess whether someone had maintained the optimal rate of signals over a representative period of time.

Though drawing detailed analogies between the compliance errors discussed by Grady and errors made by police in warrant applications is not my purpose here, the analogy from tort law suggests that it is not unprecedented for the law to set the level of reasonable mistake for some kinds of errors at zero. In addition, one rationale for the no-forgetting rule in tort law would also support a no-forgetting rule in the law of the good faith exception. It is just as hard to imagine courts accepting compliance-rate arguments- "even though I forgot to address the nexus requirement in this affidavit, this is the first time I've ever forgotten"-in the good-faith context as in the negligence context.

In addition, Fourth Amendment law sometimes does seem to expect perfection in mundane clerical tasks like filling out and reviewing warrants, affidavits, police records, and the like. If a magistrate makes

385. Nondurable precautions must be repeated frequently in order to be effective, whereas durable precautions (e.g., a safety guard on a piece of machinery) can promote safety on an ongoing basis. Grady suggests that the economic approach to negligence analysis inspired by Judge Hand's opinion in United States v. Carroll Towing Co., 159 F.2d 169 (2d Cir. 1947), applies more readily to durable than to nondurable precautions.

386. Grady, supra note 382 , at 302 .

387. Id. at $306-7$.

388. Id. at 307 . 
an error in preparing or proofreading a warrant, we of course say that the magistrate erred and that the warrant was invalid even though the evidence will probably be admitted under Leon anyway. Other pockets of strict liability in Fourth Amendment law have more bite. Consider errors by police clerks in maintaining records of outstanding arrest warrants. Although Arizona v. Evans ${ }^{389}$ held that such errors by court clerks can be excused under the good faith exception, most courts have refused to apply Leon to similar clerical errors by law enforcement personnel. ${ }^{390}$ And this is true although even the most conscientious police clerks will occasionally make a clerical error in updating police records. The law holds them to a standard of perfection, and presumably does so for reasons similar to those that justify tort law's no-forgetting rule. Because there is no way to tell whether a police clerk's error rate is optimal or not, it may be impossible as a practical matter to achieve the correct amount of deterrence. The choice is one of overdeterrence/strict liability or underdeterrence; and because the consequences of underdeterrence (i.e., unjustified arrests, etc.) are significant, overdeterrence seems the better course. It seems puzzling to say that Fourth Amendment law should hold police clerks to a higher standard in clerical tasks than police officers, for there is no reason why clerks should be more proficient in these tasks than police officers. When one adds to these considerations the fact that a bright-line rule requiring perfection in the warrant application process preserves all the perjuryreducing benefits of the warrant process, the case for adopting the Ninth Circuit approach seems fairly strong.

These arguments, however, ultimately fail to show that every error in the warrant application process should be punished with suppression. The real question under Leon is not simply whether the reasonable police officer is better than the reasonable police clerk at clerical functions. The real question is whether there is anything to be gained by suppression, and that depends on the likelihood that suppression will influence the relevant actors and that changes in their behavior will affect substantive Fourth Amendment values. I can illustrate the point by considering how courts have treated clerical errors by magistrates and clerks under Leon and Evans.

When a magistrate issues a search warrant that is insufficiently particular or is unsupported by probable cause, citizen privacy is at

389. 514 U.S. 1 (1995).

390. See supra note 64 and accompanying text. 
risk. $^{391}$ No matter how egregious the magistrate's error, however, suppression usually will be inappropriate in such a case because the Supreme Court has decreed that magistrates cannot be influenced by the prospect of suppression. ${ }^{392}$ Suppression of evidence obtained because of the magistrate's faulty review is appropriate only when it will affect police officers or other officials who are part of the law enforcement team. The same analysis applies to the court clerks in Evans-their mistakes in maintaining up-to-date arrest warrant records certainly put the privacy of citizens at risk, but the Court refused to suppress anyway because the clerks, not being adjuncts of law enforcement, would not be influenced to be more careful by the prospect of exclusion.

In contrast, mistakes made by police clerks pose a more complicated case. Police clerks, as "adjuncts of law enforcement," can generally be influenced by the prospect of suppression. In addition, their mistakes in maintaining law enforcement records put substantive privacy rights at risk. ${ }^{393}$ Both these points suggest that evidence should be suppressed when the Fourth Amendment is violated through police reliance on records created by police clerks. A complication arises, however, because some types of clerical errors by police clerks (e.g., data entry errors) cannot be completely deterred. ${ }^{394}$ If the incentives created by suppression cannot induce perfect compliance, then at some point the application of the exclusionary rule penalizes law enforcement without any corresponding increase in privacy. This creates a Fourth Amendment analogue to the pocket of strict liability within negligence doctrine discussed by Grady.

What are the implications of this analysis for police officer errors in filling out warrant applications? We know, of course, that as a general matter police officers are influenced by the prospect of exclusion - that is a fundamental assumption of Leon. We also know that ordinarily

391. There may be some situations where magistrate error does not threaten substantive privacy rights. Perhaps Groh and Sheppard are such cases, for in those cases the magistrate's errors were "harmless" to the search targets because the searches would have been carried out in exactly the same manner if the magistrates had done their jobs properly. Cf. Alschuler, supra note 19, at 34445 (suggesting that the Court might have used harmless error analysis to justify the result in Sheppard).

392. See United States v. Leon, 468 U.S. 897, 917 (1984) (stating that the exclusion of evidence cannot be expected to have a significant deterrent effect on judges or magistrates).

393. Distinguishing so sharply between court clerks and police clerks seems odd, but it is a natural byproduct of Leon's tendency to lump various government officials into the categories of "deterrables" and "nondeterrables." That tendency is regrettable, see Alschuler, supra note 19, at $351-57$, but understanding it is essential to understanding Leon.

394. Cf. GUIDO CALABRESI, THE COSTS OF ACCIDENTS 109-11 (1970) (explaining that there are limits to the effectiveness of deterrence because individuals cannot control all their acts). 
suppression is appropriate when an officer errs by submitting a warrant application so lacking in indicia of probable cause that no reasonable officer would rely upon it. In the ordinary case where the application contains all the information supporting probable cause gathered by the officer, suppression is appropriate because the submission of an affidavit unworthy of reliance will result in an unjustified search if the magistrate errs by issuing the warrant. The situation looks different, however, if we assume that the officer actually had probable cause for the search and erred only in the process of filling out the warrant application. Now errors by the magistrate will not result in searches unsupported by probable cause. $^{395}$ Do these police clerical errors warrant application of the exclusionary rule?

As in my prior discussion of the argument that all inadvertent mistakes in the warrant application should be excused, it is necessary here to distinguish different sorts of errors in the warrant application process. In a Type II case like the Eighth Circuit's Martin or Carpenter, the error is one that reflects carelessness on the part of the officer and can therefore be effectively deterred. Fourth Amendment law should do all it can to encourage police officers to think carefully about whether the facts uncovered in their investigations add up to probable cause and to encourage their departments to train them to do so. Even if the officer actually has probable cause for a particular search, deterring carelessness in the application process will reduce the number of bad searches over the long haul. ${ }^{396}$ In a Type III or IV case, on the other hand, the error may be one that even the most rigorous training programs would not eliminate. If the error cannot be deterred and the officer actually has probable cause for the search, a rule requiring suppression seems to serve little Fourth Amendment purpose. For these reasons, I conclude that courts need not suppress evidence in every case where error in the warrant application process renders the affidavit too scanty to support

395. If the affidavit presented to the magistrate does not establish probable cause and the magistrate approves it, the warrant would be invalidly issued and there would be a Fourth Amendment violation. The violation is peculiar, though, in that it is hard to see how the target of the search is harmed. If the officer had filled out the application properly and/or the magistrate had done her job properly, the same search still would have taken place. Cf. Transcript of Oral Argument at 38-39, Groh v. Ramirez, 540 U.S. 551 (2004) (No. 02-811), available at 2003 WL 22659269 (suggesting that damages in the case could only be nominal because the same search would have taken place if the officer had properly filled out the warrant application).

396. The point here is structurally similar to the one the Court made in Agnello v. United States, 269 U.S. 20 (1925). There, the Court held that an officer's failure to obtain a warrant violated the Fourth Amendment and merited exclusion of the evidence even though it was undisputed that the officer had possessed probable cause for the search. Id. at 33-35. Exclusion was necessary to deter end runs of the warrant process because that process will reduce the number of bad searches over time, even if the search in the instant case was supported by probable cause. 
reasonable reliance. Instead, courts should treat officers as having a duty to exercise reasonable care in the warrant application process, and should suppress evidence only where the officer's mistake is unreasonable. This seems preferable to the all-or-nothing approaches taken by the Eighth and Ninth circuit views.

\section{Selective Transmission and the Meaning of "Reasonable Mistake"}

The tricky part, of course, is drawing the line between reasonable and unreasonable errors in the warrant application process. If courts interpret the idea of reasonable error too broadly, all the difficulties caused by the breakdown of acoustic separation come back to the fore. If officers begin to behave as though they have some comfortable margin for error in filling out the warrant application, the privacy protections imposed by the discipline of the warrant process are compromised and we are back on the slippery slope toward the problems generated by the Eighth Circuit view. The notion of reasonable error only makes sense in cases where the officer's error is of the sort that cannot be eliminated by training and would be just as likely to arise in a world that followed a bright-line rule like the Ninth Circuit's. In other words, the notion of reasonable error should be interpreted by courts in accordance with a strategy of "selective transmission"-narrowly enough that no officer would be comfortable relaxing his efforts in preparing the warrant application because of the prospect that reasonable errors would be forgiven. Whenever an error might have been encouraged by the possibility of forgiveness under the good faith exception, no forgiveness should be forthcoming. ${ }^{397}$

If interpreted along the lines suggested here, a rule allowing suppression hearing testimony to correct reasonable mistakes in the warrant application process makes sense on several levels. First, it would reduce the strict liability component of Fourth Amendment law by removing penalties for unavoidable error without undermining the protections provided by the costs and discipline of the warrant application process. Second, it would be consistent with the way the courts have treated "implicit reliance" cases like Procopio. These cases uniformly (if inexplicitly) allow suppression hearing testimony to cure minor omissions from the affidavit and are very difficult to square with the hard-line approach taken by courts adopting the Ninth Circuit view.

397. Again, Professor Dan-Cohen's remark that a defense like duress "melt[s] away as soon as one relies upon [it]" is instructive. Dan-Cohen, supra note 6 , at 671. 
Third, the rule would have the additional benefit of flatly ruling out the possibility of suppression hearing perjury in those cases where the risk of perjury is greatest: Type I and Type II cases where the gaps in the affidavit to be filled by suppression testimony are larger.

\section{E. What About Perjury?}

I have argued that, if properly developed and interpreted, a rule allowing suppression hearing testimony to cure reasonable mistakes in the warrant application process would recognize the limits of deterrence without undermining the privacy protections created by the discipline of the warrant application process. That dispenses with one argument for the Ninth Circuit view. What, though, of the warrant application process's role in preventing perjury? Do concerns about perjury prevention provide an alternative justification for a bright-line rule forbidding the use of suppression hearing testimony to establish the officer's good faith?

Perhaps the strongest argument for the Ninth Circuit approach is that anything short of a bright-line prohibition against the use of suppression hearing testimony to establish good faith threatens to rob the warrant process of at least some of its effects in curtailing police perjury. The weakness of the Ninth Circuit's rule is that, like any bright-line rule, it can potentially sweep much broader than its justification. In this context, the point is especially troubling because some of the reported cases appear to involve little or no risk of police perjury. In Corrigan, for example, the arrest warrant application made it clear that the officer knew the information was fresh at the time of his application for the search warrant and simply made a transmission error in filling out the second application. ${ }^{398}$ In Procopio, the facts of the case virtually eliminated the possibility that the officers lied in explaining how they knew that the suspect lived in the apartment to be searched. ${ }^{399}$ It seems, then, that on at least some occasions a bright-line rule would result in suppression even where there is little reason to doubt that police were being completely truthful.

398. See United States v. Corrigan, 809 F. Supp. 567, 569 (M.D. Tenn. 1992) (stating that the officer gave the date of an incriminating conversation with the defendant when applying for the arrest warrant, but not when applying for the search warrant).

399. See United States v. Procopio, 88 F.3d 21, 28 (1st Cir. 1996) (stating that the officers discovered the correct address for the challenged search warrant while executing arrest and search warrants at the defendant's building). 
Whether this cost is worth paying depends on how good a job warrants actually do in reducing police perjury. More precisely, it depends on whether the reduction in perjury from a bright-line rule would be outweighed by the number of cases in which evidence would be suppressed even though the police actually had probable cause. This is, in principle, an empirical question, but we lack the data to answer it empirically and probably always will. Having no choice but to engage in armchair speculation, ${ }^{400}$ I suggest that here the cost-benefit analysis probably speaks against a bright-line rule because there are significant limits on the extent to which the warrant application process can prevent perjury. ${ }^{401}$ If police are willing to lie, the lying can be displaced into other areas. ${ }^{402}$ For example, officers who find the warrant requirement too onerous can resort to consent searches-a prospect that is all too inviting because the Supreme Court has made the consent standard so easy to satisfy. ${ }^{403}$ If the defendant disputes the consensual nature of the search, the issue will be litigated in a suppression hearing where the officer will enjoy the full advantages of the credibility gap discussed by Professor Stuntz. ${ }^{404}$ The Court's relatively permissive approach to confidential informants also limits the warrant requirement's ability to curtail police perjury. A police officer who wishes to beat the warrant requirement through perjury will not try to do so by leaving a gap in his affidavit and then trying to plug the gap with suppression hearing testimony. Instead, he will lie up front-most likely by concocting a "reliable and confidential" informant. As Stuntz has pointed out, there is

400. Cf. Stuntz, supra note 317 , at 935 (noting that arguments about warrants and police perjury involve "guesswork" and are "necessarily speculative").

401. See id. at 937-41 (describing the difficulties and complications of using the warrant requirement to prevent police perjury).

402. See id. at 938 ("If the law prevents perjury in cases of one type but not in cases of another, a dishonest officer can simply re-describe the case, changing his story to take advantage of whatever opportunities the law gives him."). Professor Stuntz discusses the most well-known example of this phenomenon: one study found a substantial increase in the number of "dropsy cases" (i.e., cases where an officer claimed that a suspect dropped narcotics evidence while fleeing police, making police possession of the evidence the result of a legal, plain-view seizure) after the Supreme Court extended the exclusionary rule to the states in Mapp v. Ohio, 367 U.S. 643 (1961). Stuntz, supra note 317, at 937-38 \& n.149 (discussing Barlow, Patterns of Arrest for Misdemeanor Narcotics Possession: Manhattan Police Practices 1960-62, 4 CRIM. L. BULL. 549, 555-60, 570 (1968)).

403. See William Stuntz, Race, Class, and Drugs, 98 Colum. L. REv. 1795, 1823 (1998) (stating that the Supreme Court's approach to consent searches "resolves into a kind of 'Jeopardy' rule: If the officer approaches the suspect and puts the command to empty his pockets in the form of a question, the resulting search is consensual"). For a recent discussion of the Supreme Court's jurisprudence on consent searches, see generally Steven L. Chanenson, Get the Facts, Jack! Empirical Research and the Changing Constitutional Landscape of Consent Searches, 71 TENN. L. REV. 399 (2004).

404. Stunz, supra note 317, at 914-15. 
no way that the warrant process can seriously check perjury unless the Court becomes more restrictive in its approach to confidential informants. Such a change of heart is unlikely because the use of informants is so critical to narcotics enforcement. ${ }^{405}$

These general points are still more telling in the present context. The question at this point in my analysis is not about the potential for perjury at suppression hearings in general, but about the potential for perjury in cases where the gaps to be filled by suppression hearing testimony result from reasonable mistakes in the warrant application process. I have argued that the reasonable-mistake standard should be hard for the prosecution to meet because courts should interpret as reasonable only those mistakes that cannot realistically be eliminated by better training. If the standard is not met, the risk of perjury would be nonexistent because the trial court would refuse to entertain testimony that sought to remedy unreasonable errors in the warrant application. Where an omission from the affidavit is reasonable, the gap in the affidavit will be small and the officer's suppression hearing testimony will be significantly constrained by the information included in the warrant application. These points suggest that the risk of perjury if suppression hearing testimony were allowed to correct reasonable mistakes in the warrant application would be quite manageable. I conclude that perjury concerns are not sufficient to justify a bright-line prohibition against the use of suppression hearing testimony to establish the officer's good faith.

If a bright-line rule is unnecessary, the remaining question with respect to the perjury variable is whether courts should impose some heightened standard of proof when evaluating suppression hearing testimony offered to establish an affiant's good faith. There are legitimate concerns that even in cases where the affidavit's deficiencies are small enough to look like the result of a reasonable mistake, the credibility gap and hindsight bias problems endemic to suppression hearings might sway courts to credit perjured testimony. Given that anything short of a bright-line rule contains some potential for abuse, a heightened proof standard such as clear and convincing evidence seems a modest and sensible step. ${ }^{406}$ Such a standard would remind courts to

405. Id. at 938-41. Stuntz observes that this is one of the many ways in which the "War on Drugs" has influenced the law of criminal procedure.

406. See id. at 912 n.69 (observing that burden of proof rules are one common way of dealing with hindsight bias). Professor Sherwin has discussed an analogous issue in considering proposals to excuse non-compliance with will formalities (e.g., a rule that the will must be signed by two witnesses in the presence of the testator and of each other) if there is clear and convincing evidence of testamentary intent. Emily Sherwin, Clear and Convincing Evidence of Testamentary Intent: The Search for a Compromise Between Formality and Adjudicative Justice, 34 CONN. L. REV. 453 
guard against the risk of perjury created by allowing suppression hearing testimony to rehabilitate warrants. Where the officer's story seems doubtful, courts should refuse to credit the testimony and should suppress the evidence.

\section{F. Rules Versus Standards: An Objection and Response}

I have argued, then, that suppression hearing testimony about information omitted from the warrant application can be used to establish an officer's good faith if the omission resulted from a reasonable mistake and the prosecution can prove by clear and convincing evidence that the omitted information was known to the officer at the time of the warrant application. This approach imposes a duty to use reasonable care in filling out the warrant application, but regards some mistakes in the application process as reasonable because they cannot realistically be eliminated by greater police training. I have argued that if suitably interpreted, this recognition of reasonable mistakes in the warrant application process will neither encourage laxity in the preparation of warrant applications nor pose unmanageable risks of perjury.

Most criminal procedure scholars will, I suspect, readily accept my conclusion that an approach like that of the Eighth Circuit must be rejected because it tends to undermine the self-imposed discipline of the warrant process while creating unduly great risks of police perjury. They will likely be reluctant, however, to join me in rejecting the Ninth Circuit's bright-line ban on proving good faith through suppression hearing testimony. One possible ground of such reluctance is an argument that we ought to hold tenaciously to any rule that helps prevent police perjury because the problem is a very serious one and the judicial means of controlling it are so limited. I certainly share the concerns

(2002). Sherwin explains that "[a] judicial power to dispense with formality requirements, in comparison with the traditional rule of strict enforcement, increases decisional accuracy. Combining this power with a clear and convincing evidence standard diminishes its accuracy, but the higher standard of proof minimizes danger to the functions of the traditional formality requirements." Id. at 464. One can view my proposed rule in a similar light. I relax the "warrant formality" requiring that all information supporting probable cause be included in the affidavit (or otherwise presented to the magistrate) in the service of decisional accuracy, i.e., outcomes that more closely track the relevant policies. The relaxation of the formality rule threatens to reduce the rule's effectiveness in curbing perjury, but the heightened proof standard of clear and convincing evidence helps to minimize this danger. Sherwin ultimately concludes that this sort of compromise does not work well in the context of wills, and she suggests that it may also be unstable in other contexts. Id. at $466,475-76$. I see no reason, however, why the coupling of a "dispensation rule" allowing consideration of information omitted from the affidavit through reasonable mistake and a heightened proof standard would be unstable in the context of the good-faith inquiry. 
behind this argument, but I have already tried to explain why my proposed solution should not pose unmanageable risks of police perjury. At another level, however, the reluctance may be rooted in a view that the advantages of having a bright-line rule in the context of suppression hearings more than compensate for its inaccuracies in some cases. Someone influenced by the work of Frederick Schauer ${ }^{407}$ or Larry Alexander and Emily Sherwin ${ }^{408}$ might raise the following objection:

In essence, your argument is that the Ninth Circuit rule would sweep too broadly and thus result in the suppression of evidence in cases where suppression would neither increase the level of care in the warrant process nor prevent perjury. It is natural enough to say that excluding evidence in these cases would just be "mindless formalism" and that a more tailored rule like the one you propose would track the underlying policies more accurately. ${ }^{409}$ What you are leaving out, though, is that this kind of gap between a rule's scope of application and its underlying rationale is an inevitable consequence of having a "serious rule" at all. It is the essence of any serious rule to be "entrenched against its background justification" so that the rule will apply even in circumstances where the underlying purposes of the rule are not served, ${ }^{410}$ and the Ninth Circuit rule is a serious rule. When we

407. See, e.g., Frederick SChauer, Playing By The Rules: A Philosophical Exploration of Rule-Based Decisionmaking (Tony Honoré \& Joseph Raz eds., Clarendon Press, 1991); Frederick Schauer, Formalism, 97 Y ALE L.J. 509 (1988).

408. See, e.g., LARRY AleXANDER \& EMILY SHERwIN, THE Rule of RULES: Morality, Rules, AND THE DILEMMAS OF LAW (Duke University Press, 2001); Alexander \& Sherwin, supra note 106.

409. $C f$. Frederick SChauer, Profiles, Probabilities and Stereotypes ix $-\mathrm{x}$ (2003) (explaining that his intention in the book is to defend "the morality of decision by categories and by generalizations" against what he describes as our contemporary "resistance to generalization" and "sympathy for the particular").

410. Here the objector is drawing on the largely consistent accounts of rule-based decision making developed by Schauer and by Alexander and Sherwin in the works cited supra notes $407-08$. Alexander and Sherwin use the phrase "serious rules" to denote legal norms that are especially effective in settling disagreements and guiding conduct precisely because they are "opaque to the moral principles they are supposed to effectuate." ALEXANDER \& SHERWIN, RULE OF RULES, supra note 408, at 30. Similarly, Schauer speaks of "real rules" as entrenched against their background generalizations: "it is exactly a rule's rigidity, even in the face of applications that would ill serve its purpose, that renders it a rule." Schauer, Formalism, supra note 407, at 535 . While I cannot do justice to the richness of their accounts in the context of this Article, the objection set out in the text can be more fully appreciated in the light of a brief account of the distinctive characteristics of "serious rules." A brief discussion will also help to avoid potential confusion about terminology.

While the term "rule" has many meanings and, in the context of articles like this one, is often used as a general term for any sort of legal norm, Alexander and Sherwin helpfully differentiate "serious rules" from "rules of thumb," principles, and standards. ALEXANDER \& SHERWIN, RULE OF RULES, supra note 408, at 26-32. Rules of thumb (their example is "As a rule, you should drive slowly rather than drive fast") offer defeasible advice about what to do- "they can be heeded or ignored but never 'obeyed' or 'violated." Id. at 27 . In contrast, a serious rule can be obeyed or violated because it "purports to state a prescription applicable to every case that falls within the rule's factual predicate or hypothesis." Id. In contrast to (moral) principles, serious rules are posited 
confine our attention to any particular case where application of a rule seems harsh (e.g., Corrigan), replacing the rule with a standard like "reasonable mistake" will always seem to increase decisional accuracy because standards are more responsive to background policies. ${ }^{411}$ But despite their inevitable inaccuracy in particular cases, rules can sometimes decrease the overall rate of error over time. ${ }^{412}$ Serious rules, as Schauer says, are about the allocation of decision-making authority ${ }^{413}$ - and use of a rule can be justified precisely because it is undesirable to give decision makers the power to weigh a rule's application in a particular case against its background purposes. ${ }^{414}$

Now consider the application of these ideas to the question of

norms that come into existence at a particular place and time. Id. Finally, a serious rule is distinguished from a standard by its greater determinateness, which in turn is a function of the rule's being "opaque to the moral principles [it] is supposed to effectuate." Id. at 30 . A standard, in contrast, is a posited norm that "contain[s] vague or controversial moral or evaluative terms" in its formulation and hence is "transparent to background moral principles and requires particularistic decision-making." Id. at 29-30. The rule/standard distinction is, of course, a familiar one that has generated a vast literature. Some influential discussions include Duncan Kennedy, Form and Substance in Private Law Adjudication, 89 HARV. L. REV. 1685 (1976); Pierre J. Schlag, Rules and Standards, 33 UCLA L. REV. 379 (1985); Kathleen M. Sullivan, Foreword: The Justices of Rules and Standards, 106 HARV. L. REV. 22 (1992).

411. See AleXANDER \& Sherwin, RULe OF RULES, supra note 408, at 34-35 (explaining that serious rules are inherently imperfect because they are necessarily both over- and under-inclusive relative to background moral principles); see also Schauer, Formalism, supra note 407, at 542 ("A decisionmaker can never exceed the optimal result based on all relevant factors. Thus, a rule-bound decisionmaker, precluded from taking into account certain features of the present case, can never do better but can do worse than a decisionmaker seeking the optimal result for a case through a rule-free decision.").

412. In Alexander and Sherwin's account, "serious rules" are interesting and important because their relative determinacy enables them to fulfill "the moral functions that the rules are meant to serve: coordination, expertise, and efficiency." ALEXANDER \& SHERWIN, RULE OF RULES, supra note 408 , at 30 . Attempts to directly apply moral principles to particular cases lead to "the controversy and uncertainty that results in lack of coordination, costly deliberation, and mistaken (inexpert) conclusions." Id. Serious rules can eliminate these problems to the extent that it is easier for decisionmakers to apply the rule correctly and consistently in particular situations than it is for them to apply the moral principles underlying the rule. Id. at 31 . Alexander and Sherwin provide a helpful example of how a serious rule can improve decision-making accuracy over time despite its inherent imperfections:

[S] uppose Lex [the fictional lawgiver used throughout THE RULE OF RULES] knows that frequent strong tides make swimming dangerous at a certain site. In a world of perfect reasoners, no rule would be necessary because all people would correctly judge whether and when they should swim. In fact, most people lack the information necessary for accurate judgment: some may understand the tides well enough to know when it is safe to swim, and others may be strong enough to resist the tides; but too many will err and swim when they should not. As a result, considerable public and private resources will be devoted to rescuing hapless swimmers. As long as Lex's information is superior to that of most of his subjects, and as long as it is not practical to identify the experts among them, the best course is for Lex to enact a serious rule, "No swimming."

Id. at 55

413. Schauer, Formalism, supra note 407, at 540-44.

414. See id. 
whether suppression hearing testimony can be used to establish the officer's good faith. The Ninth Circuit approach functions as a serious rule disabling judges from making case-by-case decisions about whether the testimony might be perjured and whether the evidence supporting probable cause was omitted from the warrant application because of a reasonable mistake. No doubt judges applying this rule will get some cases "wrong" rule will result in the suppression of evidence in some cases where suppression would serve no Fourth Amendment purpose. ${ }^{416}$ But surely judges authorized to make case-by-case decisions will make a lot of mistakes in the other direction by construing reasonable mistake too generously and crediting perjured testimony despite the clear and convincing evidence standard. This is not to impugn the integrity or intelligence of judges, but rather to call attention to the dynamics peculiar to the suppression hearing. As you described earlier, Professor Stuntz has explained the various ways in which suppression hearings make perjury easier. ${ }^{47}$ And if a court believes an officer's testimony that he omitted information from the warrant application through an innocent mistake, it will undoubtedly be reluctant to rule that the mistake was unreasonable enough to warrant suppression. Possible systemic effects in undermining the police commitment to the warrant process would likely seem less pressing than the immediate prospect of a criminal going free because the constable has blundered in preparing his affidavit. ${ }^{418}$ Do not these considerations suggest that, in the long run, the Ninth Circuit rule will improve decisional accuracy and will better promote the underlying Fourth Amendment policies than the more flexible standard you propose?

This objection is a powerful one; indeed, I think it is the strongest argument for rejecting my proposed view in favor of the Ninth Circuit alternative. While I am convinced that my approach is superior to that taken by the Eighth Circuit, this argument suggests that the choice between my position and the Ninth Circuit's is a close one. Still, I have three points to make in response.

To begin, I think that both my imagined objector and I must acknowledge that the fate of the objection chiefly depends on empirical

415. Obviously, I do not mean that their decisions would be wrong, all things considered. If a serious rule is justified, the decisions would be correct, all things considered. They would be "wrong" only in the sense that they would diverge from the choices that would be made by a perfect particularistic decision maker.

416. More precisely, it would serve no Fourth Amendment purpose cognizable under Leon. Suppressing evidence when the affidavit is woefully lacking in probable cause might be valuable as a way of encouraging magistrates to scrutinize affidavits more closely, but (as has already been discussed at length) that purpose does not count under Leon.

417. See supra notes $331-42$ and accompanying text.

418. Here, of course, the objector is paraphrasing Justice Cardozo's famous quip about the exclusionary rule. See People v. Defore, 150 N.E. 585,587 (N.Y. 1926) ("The criminal is to go free because the constable has blundered."). 
predictions about the behavior of judges. Such predictions are hard to make in a principled way. According to the objection, the principal justification for a bright-line rule against proving good faith with suppression hearing testimony is that it will reduce the rate of error over time. In this context, we know that judges applying the Ninth Circuit rule sometimes will reach the wrong result by excluding evidence in cases where it ought to be admitted. On the other hand, we know that judges operating under my proposed standard will err by admitting evidence that should be excluded. The question of whether the Ninth Circuit rule is justified ultimately depends on which set of errors would be more frequent, ${ }^{419}$ and this is something we simply do not know. ${ }^{420}$ I have made the case that if judges appreciate the relevant policies, they can allow suppression hearing testimony to establish good faith on a case-bycase basis without compromising the protections of the warrant application process. One might reasonably consider that assessment too optimistic, but only experience under my proposed standard could prove it so. If courts adopted my approach but proved unwilling or unable to apply it narrowly, I might reconsider my position and advocate adoption of the Ninth Circuit rule. ${ }^{421}$

A second point I wish to make quite briefly is that adoption of the Ninth Circuit's bright-line rule is in some tension with Leon's insistence that suppression in warrant cases should be ordered "only on a case-bycase basis and only in those unusual cases in which exclusion will further the purposes of the exclusionary rule."422 While hardly dispositive, the passage suggests that Leon envisions a regime of standards rather than rules-a regime where the norms governing application of the exclusionary rule are meant to be transparent to the background purposes of the rule.

419. Alexander and Sherwin put the general point well: "the function of a rule is to require uniform conduct when this is the best course of action for most of those who are subject to the rule. If, among the sum of actions governed by the rule, more harm would result from mistaken judgment than from compliance with the rule, the rule is justified." ALEXANDER \& SHERWIN, RULE OF RULES, supra note 408 , at 55 .

420. Schauer explains that genuine rules always restrict decision-making authority. Whether this is a liability or an asset depends on how well the decision makers are likely to do; the problem, as Schauer notes, is predicting the behavior of the relevant decision-makers. Schauer, Formalism, supra note 407 , at $543-44$.

421. In this respect, my attitude is similar to that expressed by Justice Blackmun in his Leon concurrence. Justice Blackmun argued that the correctness of Leon ultimately depended on a defeasible empirical prediction that suspending the exclusionary rule for most warrant searches would have no significant effect on police compliance with the Fourth Amendment. He insisted that the Court should reconsider Leon if experience proved that prediction false. United States v. Leon, 468 U.S. 897, 927-28 (Blackmun, J., concurring).

422. Id. at 918 (majority opinion). 
This second point suggests a third, which is far more important. The objection being considered suggests that the Ninth Circuit rule would reduce judicial error in the long run by disabling judges from making case-by-case, policy-sensitive judgments about whether suppression hearing testimony establishes the affiant's good faith. The worry is that without a firm rule, too many judges will exercise their discretion to favor law enforcement interests at the expense of Fourth Amendment protections. It may be unrealistic, though, to think that a bright-line rule against proving good faith through suppression hearing testimony could really cabin judicial discretion in the way the objection envisions. The problem is that, if generally adopted, the Ninth Circuit rule would be one serious rule awash in a sea of standards. As just noted, Leon explicitly invites courts to decide cases by referring directly to the purposes of the exclusionary rule, and the governing norms for the review of a magistrate's probable-cause determination leave considerable room for discretion. Specifically, a court that is bound by a bright-line rule barring the use of suppression hearing testimony to prove good faith but believes suppression would not serve the purposes behind the exclusionary rule will generally ${ }^{423}$ still have the option of saying that the affidavit actually provided the magistrate with a "substantial basis for ... conclud[ing]' that probable cause existed" ${ }^{324}$ or that it at least contained sufficient indicia of probable cause to justify good-faith reliance. ${ }^{425}$ In other words, the Ninth Circuit rule might serve not to reduce judicial error, but to channel it into other areas where it might do even more harm to the integrity of the warrant process.

The Sixth Circuit's decision in United States v. Carpenter ${ }^{426}$ provides an instructive example. There, an initial panel opinion relied on material omitted from the warrant application in applying the good faith exception. ${ }^{427}$ This proved controversial, and when the case was reheard en banc a majority of the court ducked the question of whether information omitted from the affidavit could be used to establish the officer's good faith. ${ }^{428}$ Instead, the en banc court held that the affidavit,

423. I say generally because, in any given jurisdiction, particular precedents might foreclose this maneuver. In most instances, the fact-specific character of probable-cause determinations makes it relatively easy for courts to distinguish unfavorable precedents.

424. Illinois v. Gates, 462 U.S. 213, 238-39 (1983) (quoting Jones v. United States, 362 U.S. $257,271(1960))$.

425. Leon, 468 U.S. at 923.

426. 360 F.3d 591 (6th Cir. 2004) (en banc), cert. denied, 543 U.S. 851 (2004). See also supra notes 283-90 and accompanying text (discussing Carpenter).

427. Id. at 594.

428. Id. at 593 . 
scanty as it was, actually contained sufficient indicia of probable cause to support reasonable reliance. ${ }^{429}$ From the standpoint of preserving the protections of the warrant process, this result is entirely perverse. By watering down the third Leon exception in this way, the en banc opinion conveyed far more strongly than the panel opinion the message that anything signed by a magistrate is immune from meaningful judicial review. ${ }^{430}$ Matters would have been even worse had the court ruled that the affidavit had provided the magistrate with a substantial basis for finding probable cause, for that holding would not even have instructed the magistrate to be more critical in reviewing future warrant applications.

The lesson here, I submit, is that a bright-line rule flatly prohibiting the use of suppression hearing testimony to prove good faith would not prevent courts from making the sorts of errors that arise from the use of standards instead of serious rules. Instead, courts would find other ways of admitting evidence where exclusion seems not to serve the purposes of the exclusionary rule. If that is so, the objection significantly overstates its case that the Ninth Circuit's serious rule will protect the integrity of the warrant process more effectively than my proposed standard. The intuition that officers should not be penalized for reasonable mistakes in the warrant application process is a strong one that courts are likely to acknowledge in one way or another. Indeed, we have already seen evidence of this in Procopio and related cases, where courts seem to be implicitly employing an approach similar to the one I propose. It will be best if courts are allowed to openly acknowledge what they are doing and to self-consciously consider the risks that come with allowing suppression hearing testimony to prove good faith.

\section{CONCLUSION}

In his Leon dissent, Justice Brennan predicted that the good faith

429. Id. at 597.

430. In my earlier discussion, I classified Carpenter as a Type II case. Applying my proposed standard to its facts, I would hold that the omissions in the warrant application were unreasonable and that the evidence should have been excluded. Given the actual result in the case, I strongly suspect that the judges who voted with the majority also would have admitted the evidence under my standard by finding that the officers had made a reasonable mistake in the warrant application. If I am right, the example illustrates both the objection's concerns and my response to them. As the objection contends, courts may be tempted to dilute my standard in ways that undermine the integrity of the warrant process. My response is that courts who believe that suppression is unwarranted can reach the same result in other ways even if they follow the Ninth Circuit approach, and that these alternative routes may be even worse. 
exception would "undermine the integrity of the warrant process."431 Using the terminology of Professor Dan-Cohen's "acoustic separation" model, the concern was that the Leon decision rule would undermine police commitment to Fourth Amendment conduct rules. Most cases that fall within the third Leon exception seem to confirm Justice Brennan's dire predictions. When the face of an affidavit is so lacking in indicia of probable cause that no reasonable officer would have submitted it to a magistrate, the officer who did submit it would seem to have already lost all regard for the integrity of the warrant process. Nonetheless, I have tried to show in this Article that there are cases where the usual inference is unjustified-cases where officers are able to offer eminently believable testimony suggesting that the shortcomings in their warrant applications were the result of objectively reasonable mistakes. Suppressing evidence in these cases serves no Fourth Amendment purpose, and leads to an undesirable pocket of strict liability within Fourth Amendment law. However exaggerated the Supreme Court's notions of the costs of the exclusionary rule may be, those costs look rather high in cases where suppression seems to bring no benefits. Allowing limited use of suppression hearing testimony to prove good faith under Leon would address concerns about strict liability and overdeterrence, but raises hard questions about whether courts can apply the Leon decision rule on the basis of suppression hearing testimony without contributing to slippage in Fourth Amendment conduct rules. Prior to Leon, officers prepared their warrant applications with the understanding that probable cause would be judged solely on the basis of information presented to the magistrate and that omissions could result in the loss of valuable evidence. ${ }^{432}$ That rule sent a strong message that preparing the warrant application was serious business. If courts allow suppression hearing testimony to cure some kinds of mistakes in the warrant application process, will this lead officers to reduce their levels of care in applying for warrants? Will officers take advantage of judicial leniency by perjuring themselves to save threatened prosecutions?

The answers to these questions depend, I think, on how courts approach the use of suppression hearing testimony to establish good faith. If courts follow the Eighth Circuit's lead by routinely looking beyond the affidavit in the good-faith inquiry, officers are sure to get the message that the warrant application is a mere formality. I have argued, however, that suppression testimony can be used to establish the officer's

431. United States v. Leon, 468 U.S. 897, 958 (1984) (Brennan, J., dissenting).

432. Whiteley v. Warden, 401 U.S. 560,565 n.8 (1971). 
good faith without undermining the integrity of the warrant process if two conditions are met: First, the omission of the information must be the product of a reasonable mistake in the warrant application process. Second, the prosecution's claims about the omitted information must be proven by clear and convincing evidence. Again, the key to the ultimate workability of my proposal is that courts must interpret the notion of reasonable mistake narrowly, using a strategy of selective transmission to minimize the conduct side effects of a more permissive decision rule. To the extent that an officer's mistake could realistically be affected by training, it should not be regarded as objectively reasonable. This approach is faithful to the spirit of Leon in recognizing the limits of deterrence while preserving the privacy protections the warrant requirement can still provide even when magistrates fail to perform their constitutional roles. 